U norden

\title{
Nordic Monitoring of diet, physical activity and overweight
}

Validation of indicators

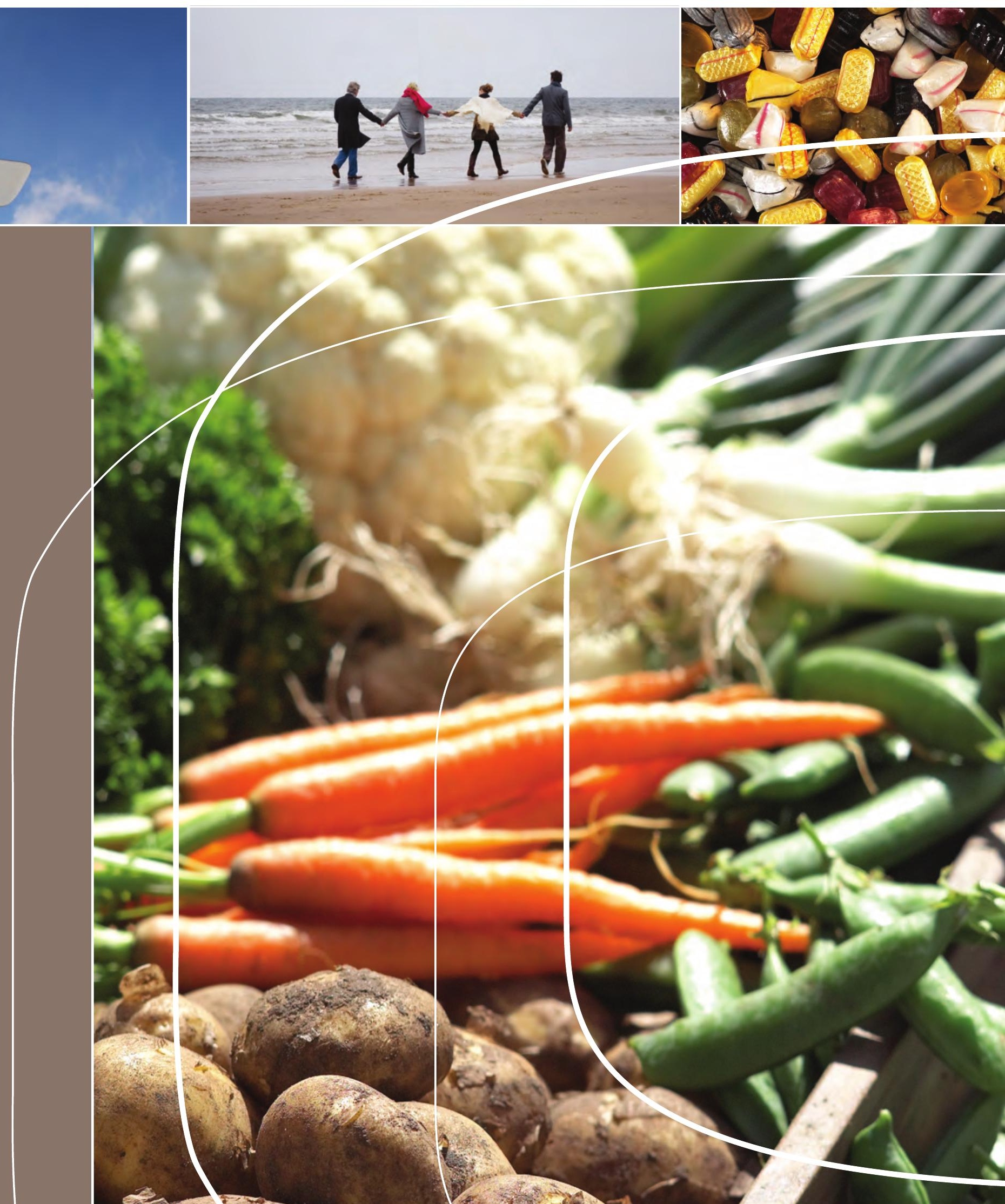



4 norden 



\title{
Nordic Monitoring of diet, physical activity and overweight
}

\author{
Validation of indicators
}

Fagt S, Andersen LF, Anderssen SA, Becker W, Borodulin K, Fogelholm M, Groth MV, Gunnarsdottir I, Helakorpi S, Kolle E, Matthiessen J, Rosenlund-Sørensen M, Simonen R, Sveinsson T, Tammelin T, Thorgeirsdottir H, Valsta L and Trolle E 
Nordic Monitoring of diet, physical activity and overweight

Validation of indicators

Fagt S, Andersen LF, Anderssen SA, Becker W, Borodulin K, Fogelholm M, Groth MV,

Gunnarsdottir I, Helakorpi S, Kolle E, Matthiessen J, Rosenlund-Sørensen M,

Simonen R, Sveinsson T, Tammelin T, Thorgeirsdottir H, Valsta L and Trolle E

TemaNord 2011:556

ISBN 978-92-893-2258-4

http://dx.doi.org/10.6027/TN2011-556

(C) Nordic Council of Ministers 2012

Cover photo: ImageSelect. Bee-line, Ojo Image

Print: Kailow Express ApS

Copies: 180

Printed in Denmark

This publication has been published with financial support by the Nordic Council of Ministers. However, the contents of this publication do not necessarily reflect the views, policies or recommendations of the Nordic Council of Ministers.

www.norden.org/en/publications

\section{Nordic co-operation}

Nordic co-operation is one of the world's most extensive forms of regional collaboration, involving Denmark, Finland, Iceland, Norway, Sweden, and the Faroe Islands, Greenland, and Åland.

Nordic co-operation has firm traditions in politics, the economy, and culture. It plays an important role in European and international collaboration, and aims at creating a strong Nordic community in a strong Europe.

Nordic co-operation seeks to safeguard Nordic and regional interests and principles in the global community. Common Nordic values help the region solidify its position as one of the world's most innovative and competitive.

\section{Nordic Council of Ministers}

Ved Stranden 18

DK-1061 Copenhagen K

Phone (+45) 33960200

\section{www.norden.org}




\section{Content}

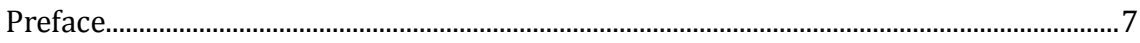

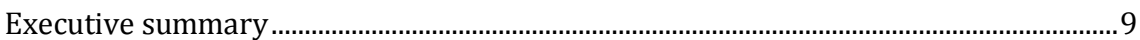

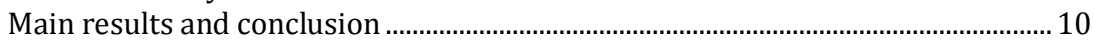

Recommendations......................................................................................................... 14

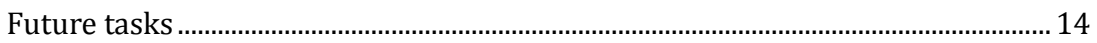

1. Establisment of a Nordic Monitoring System - part 1 of the project...................... 17

1.1 Background.......................................................................................................... 17

1.2 Establishment of the working group on a common Nordic

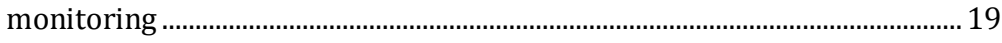

2. Validation - part 2 of the project ............................................................................ 27

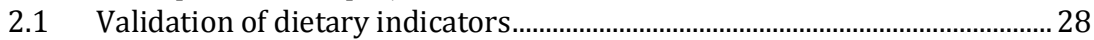

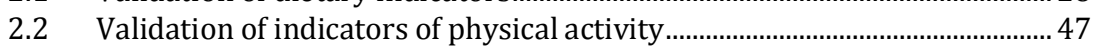

3. Indicators - which results do they provide? ...........................................................6 65

3.1 Which results can the dietary indicators provide?......................................... 65

3.2 Which results can the physical activity indicators provide?......................... 74

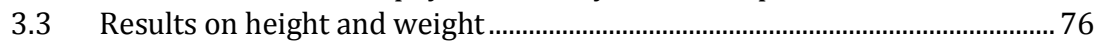

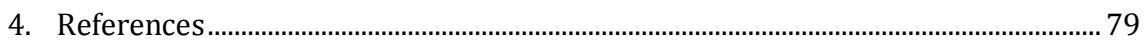

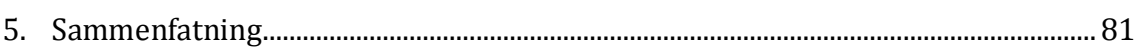

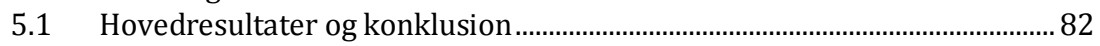

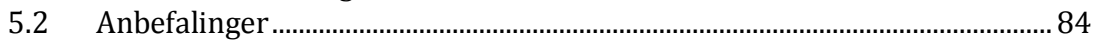

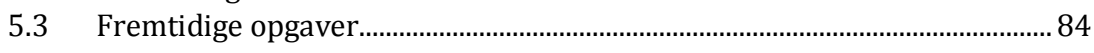

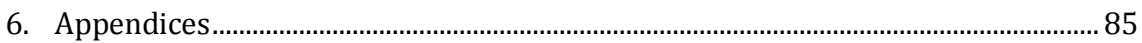





\section{Preface}

The governments of the Nordic countries have committed themselves nationally to address the issue of an unhealthy diet, physical inactivity and overweight and enacted policies to promote a healthier lifestyle. The Nordic Council of Ministers wants to underline these commitments by formulating common Nordic ambitions on combating an unhealthy diet, physical inactivity, and overweight by drawing up a joint Nordic Action Plan in 2006.

Common goals are to be created to allow for comparisons, whereby national actions taken in each of the Nordic countries can be assessed. A common ambition will be a clear benefit for the Nordic countries when coupled with a common monitoring of effects, an increased sharing of knowledge, a common effort to identify best practice, and increased scientific cooperation. Therefore in 2007, a Nordic working group was established with the aim to describe a future Nordic monitoring system on diet, physical activity and overweight.

The monitoring project consists of three parts:

- Part 1, 2007-2008: Description of a Nordic method for collecting representative data, including description of sample size and characteristics, as well as practical considerations of the implementation of the monitoring in the Nordic countries

- Part 2, 2009-2010: Validation of the suggested methods against an objective method (physical activity) or existing survey methods (diet). A network on child growth will also be started with the objective to develop a network of monitoring child health in the Nordic countries, coordinate and harmonize central monitoring using the same measures, standards and way of analyses and third to compare the development in overweight in the Nordic countries

- Part 3, 2010-2013: First collections of data in all Nordic countries

The working group has described a common Nordic method for collecting representative data based on indicator questions on diet and physical activity. The monitoring system should be simple and at relatively low cost. Therefore it has been decided to conduct the monitoring as a telephone interview. In 2009, the indicator questions were validated against 
an objective method (physical activity) or existing survey methods (diet) and the present report mainly describes the validation studies.

The project group is grateful to the following persons, who have made valuable contributions to the project: Birna Pórisdóttir, Hrefna Pálsdóttir, Rósa Ólafsdóttir and Sigrún Hreiðarsdóttir, M.Sc. students and Svandís Sgurðardóttir, assistant professor, University of Iceland; Vibeke Kildegaard Knudsen, post doc, Henrik Bach Hartkopp and Karsten Kørup, data managers, National Food Institute, Denmark; Marko Kantomaa PhD, Jussi Haapamäki student, Harto Hakonen M.Sc., LIKES Research Center for Sport and Health Sciences, Finland; Janne Halonen M.Sc., Finnish Institute of Occupational Health, Finland.

Nordic Council of Ministers

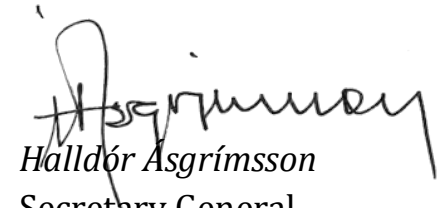

Secretary General 


\section{Executive summary}

As an important element in the Nordic Plan of Action, the Nordic Council of Ministers decided to develop a joint Nordic monitoring of diet, physical activity and overweight. A Nordic working group consisting of scientists from Nordic research institutions was established to carry out this task.

The working group has described a method for collecting representative data based on indicator questions on diet and physical activity in the Nordic countries. The monitoring system should be simple and at relatively low cost and it has been decided to conduct the monitoring as a telephone interview.

The monitoring project consists of three parts:

- Part 1. Description of a joint Nordic method for collecting representative data on diet and physical activity

- Part 2. Validation of the suggested methods against reference methods

- Part 3. First collection of data in all Nordic countries

The working group members have been:

- Lene Frost Andersen, University of Oslo, NO

- Sigmund Anderssen, Norwegian School of Sport Sciences, NO

- Ingibjörg Gunnarsdottir, University of Iceland \& LandspitaliUniversity Hospital, IS

- Thorarinn Sveinsson, University of Iceland, IS

- Holmfridur Thorgeirsdottir, Public Health Institute, IS

- Liisa Valsta \& Katja Bordulin, National Institute for health and Welfare, FI

- Tuija Tammelin, LIKES Research Center for Sport and Health Sciences, FI

- Wulf Becker, National Food Administration, SE

- Gunnar Johansson, Swedish National Institute of Public Health, SE

- Margit V. Groth, Jeppe Matthiessen, Mette Rosenlund Sørensen, National Food Institute, DK

- Sisse Fagt and Ellen Trolle (project coordinators) at the National Food Institute, DK 
The working group has held four meetings (2008-2009) and one meeting in connection to the validations studies (2009).

Additional researchers participated in the validation studies:

- Elin Kolle, Norwegian School of Sport Sciences, NO

- Satu Helakorpi, National Institute for health and Welfare, FI

- Riitta Simonen, Finnish Institute of Occupational Health, FI

The current report brings a brief summary of part 1 of the project, but describes primarily the results from part 2 - validation of the suggested questionnaires. Most of the dietary indicators have been validated in a previous Swedish study among adults. In the current study validation of dietary indicators has been carried out in Iceland (children, adolescents) and Denmark (children, adolescents and adults), whereas validation of physical activity indicators has taken place in all three age groups in Finland, Iceland and Norway. The validation study has been cofounded by NMKT as well as by Nordic Innovation under the focus area "Healthier Choices made easier for all".

Within part 2 of the project it was also decided to include a project funded by Nordic Innovation. This project had the aim of developing a network of monitoring child health in the Nordic countries and to coordinate and harmonize central monitoring using the same measures, standards and way of analyses and to compare the development in overweight in the Nordic countries.

A reference group was established within part 2 to follow the project. The reference group consisted of representatives from the Nordic food industries, agricultural institutions and manufacturers of physical activity measurement devices, as well as other Nordic Innovation project participants/leaders. The reference group's role was to give input, inspire the project development and share knowledge/information regarding future implications of outcome of the project, in order to increase knowledge and interest of using data obtained in a future monitoring system.

\section{Main results and conclusion}

The dietary indicators comprise questions on the amount of slices of bread eaten during the day or week, the eating frequency of fruit, vegetables, pommes frites/fried potatoes, fish and seafood, sausages as a main meal, candy and chocolate, cakes and biscuits, full fat cheese, soft drinks (carbonated/not carbonated, sugar sweetened), soft drinks (carbonat- 
ed/not carbonated, light/artificial sweetened) and fruit/vegetable juice; and on which type of fat used on bread and for frying, cooking, baking. The consumption of these foods has been identified as indicators of the intake of fat, saturated fat, dietary fibre and added sugar.

The results from the validation study of dietary indicators show that the frequencies of intake obtained by the dietary indicators are positively associated to the estimated intake in grams from the reference method. The results also show that the dietary indicators are able to rank individuals fairly acceptable according to their intake of foods. The dietary indicators are able to detect an intake of the macronutrients of relevance according to the goals set in The Nordic Action Plan but will as earlier stated (Fagt et al., 2009) only indirectly monitor the dietary goals and vision of the Nordic Action plan regarding macronutrients.

The working group considers that some of the dietary goals 2011 of the Nordic Action Plan will be relatively easy to monitor with simple indicator questions, as long as the goals concerns increase or reduction of certain foods. However, changes at the macronutrient level will be more difficult although the questions will to some extent be able to capture saturated fat (French fries, sausages, cheese) and added sugar (e.g. candy and soft drinks) as the suggested indicators have shown to be correlated to the intake of the macronutrients of interest.

Regarding the dietary vision of the average diet of adults meeting the NNR recommendation on salt, the working group points out that the intake of salt is difficult to measure, as the intake of salt, especially intake of household salt is difficult to assess with dietary methods. Some major salt containing foods are measured in the suggested indicators (e.g. sausages, bread, cheese, French fries (pommes frites), but not all salt containing foods are measured. As the major contributor to the salt intake is processed foods, the goal of reducing the salt intake in the Nordic population should primarily be done by reducing salt in prepared foods and this industrial approach should then be measured. The working group suggests that a Nordic project is initiated to discuss Nordic countries' experience in reduction of salt in prepared foods and how to measure the development.

In Denmark the ability to detect those not following recommended intake (specificity) of fruits and vegetables is more than $70 \%$, whereas the ability to detect those following recommendations (sensitivity) is somewhat lower. In Iceland, fruit and vegetable intake among children and adolescents is exceptionally low, which makes it difficult to assess specificity and sensitivity regarding the compliance to the recommendations on fruit and vegetable intake. 
The results indicate a good agreement between some of the foods in the dietary indicator questionnaire and macronutrients of interest, but the agreement is better for children and adults than for adolescents.

Especially fruits, vegetables, candy and chocolate, fish, sugar sweetened soft drinks and water are correlated to the intake of fat, saturated fat, dietary fibre and added sugar.

The indicators questions on physical activity ask for total time in a week, spent on both moderate-to-vigorous intensity physical activity (MVPA) and vigorous physical activity (VPA) only. The questionnaires also include questions about TV and computer time.

In the validation of the indicators of physical activity it is expected that the indicators overestimate some types of physical activity when compared to accelerometer data, as some types of physical activity is not measured by accelerometer (e.g. bicycling and swimming). The results from the validation study of physical activity indicators show that the physical activity questions work as intended in all three age groups (712, 13-17 and 18-65 y) and reflect the objectively measured levels of physical activity.

The Nordic indicator questionnaire will provide an important tool for stakeholders throughout the Nordic Region. Firstly, the indicators can be used for the Nordic Monitoring system 2011 and 2013, enabling the region to have validated and comparable data within in the area of diet, physical activity and overweight and to describe the development over time. Secondly, on a national level each country can use the indicators for several purposes and will be able to provide comparable data on a regional level, e.g. by using the indicator questionnaire in health related activities in municipalities. Thirdly, on a local level, the questionnaire provides a simple and low cost method to be used in several activities, where data on diet, physical activity and overweight are needed.

The network on childhood growth has consisted of representatives from health authorities as well as researchers involved in childhood growth. Participants in the network have been:

- Bente Moe, Helsedirektoratet, NO

- Ragnhild Hovengen, FHI, NO

- Martin Handeland, SIV, NO

- Pétur B. Júlíusson, Haukeland University Hospital, NO

- Anton Lager \& Petra Löfstedt, Swedish Nat Inst Publ Health, SE

- Max Petzold, NHV, SE

- Carl Erik Flodmark, Childhood Obesity Unit, Malmø, SE

- Anders Hjern, Social department, SE 
- Agneta Sjoberg, University of Gothenburg, SE

- Ragnheiður Erlendsdóttir, Centre for childhood; health services, IS

- Mika Gissler, Leo Dunkel, Paivi Maki, all THL, FI

- Lene Hammer Helmich, Research Centre for prevention \& health, DK

- Ellen Trolle, DTU Food, DK; Sisse Fagt, DTU Food, DK

- Lise Graversen and Carsten Obel, University of Aarhus, DK

The network has held two meetings, hosted by Nordic School of Public Health, Gothenburg, Sweden. At the meetings participants have presented ongoing activities within the Nordic region, thus improving the overview of relevant activities concerning data on childhood growth in the Nordic Countries. The meetings have elucidated how children's growth is routinely monitored in the Nordic countries and the network has identified initiatives and sources that can serve as indicators of the time trend in overweight. In both Denmark and Finland a central monitoring system of childhood growth is under construction and Sweden has similar plans, although a public discussion on central registers has postponed plans in Sweden.

The network has recognised that data to compare the prevalence of childhood overweight between the Nordic countries are available, thus creating a basis of scientific published papers, because no such data have been presented before. The network has thus held a meeting at the University of Aarhus, Denmark especially for writing an application for Nordforsk, as the network seeks to extend the network to a more scientific approach by applying for funds and has established writing groups for well-defined papers.

The network wishes to extend the monitoring aspect to cover more analytic epidemiologic aspects. This includes collaboration with Nordic cohorts such as the Northern Finnish Birth Cohort, the Aarhus Birth cohort, the National Norwegian Birth cohort and the Danish National Birth Cohort as well as researchers from other fields such as history science. The combination of these ad hoc cohorts and routine growth measures will, together with established Nordic research environment provides a unique potential for the development within this field. So far, the network has not been able to receive funding for future activities.

The reference group of the monitoring project has consisted of the following members: Steinar Høie, NHO Mat og Drikke, NO, Grethe Andersen, Danish Meat Association, DK; Karin Fisker, Danish Agricultural Council, DK; Paula Virtanen, Polar Electro Oy, FI; Jyrki Eklund, Aino Active Oy, FI; Elisabet Rytter, Swedish Food Federation, SE; Ragnheidur Hedinsdottir, Federation of Icelandic Industries, IS (and project manager of Nordic Net- 
work NTP); Kjersti Lillebø, project leader of Nordic Young Health, NO; WP leaders and the project managers (Ellen Trolle, Sisse Fagt, Carsten Obel), DK. The objective of the reference group has been to give information from the project to the reference group members and to discuss future implications of the project, in order to increase knowledge and interest of using data obtained in a future monitoring system. As the travel budget in the project has been limited, information has been sent by e-mail. Additional to e-mail communication, the project manager has participated and informed about the Nordic monitoring project on relevant meetings with reference group members.

\section{Recommendations}

The working group recommends using the dietary indicators (NFFQ) in future monitoring of diet in the Nordic Countries. However, the monitoring data on diet needs to be supplemented with additional knowledge of usual portion and serving sizes as well as eating patterns in the Nordic countries to improve interpretation of results and comparison between countries. It might be necessary to follow and update knowledge of portion sizes in the Nordic countries, as portion sizes develop over time. In interpreting the results from the NFFQ it is important to supplement with data from the national dietary surveys, as the NFFQ only indicates the level of nutrient intake.

Regarding the indicators of physical activity, the working group recommends using these questionnaires for future monitoring of physical activity in the Nordic countries. It is recommended to measure hours of accumulated activity per week in the questionnaire. However, the data on physical activity would profit from additional knowledge based on further analyses primarily by master students to improve interpretation of results.

\section{Future tasks}

The network on childhood growth will continue and extend the network to cover more analytic epidemiologic and scientific aspects, if funding is provided.

The working group on indicators will present the results of the validation studies at national and international conferences. The results of the validation studies are used in theses by scientific master students and scientific papers. Results have been presented at an international 
conference of physical activity in the Netherlands in the autumn of 2011 and it is planned to host a workshop discussing results from the monitoring project at the Nordic Nutrition Conference in Iceland in 2012. It is planned that project participants disseminate the results of the validation studies on national websites to ensure awareness of the validated indicators on both local and national level. 



\section{Establisment of a Nordic Monitoring System - part 1 of the project}

\subsection{Background}

In July 2006, the Nordic Council of Ministers - the Ministers for Fisheries and Aquaculture, Agriculture, Food and Forestry and the Ministers for Health and Social Affairs - adopted a Nordic Plan of Action on better health and quality of life through diet and physical activity.

The governments of the Nordic countries have committed themselves nationally to address the issue of an unhealthy diet, physical inactivity, and overweight and enacted policies to promote a healthier lifestyle. The Nordic Council of Ministers wants to underline these commitments by formulating common Nordic ambitions on combating an unhealthy diet, physical inactivity, and overweight. Common goals are to be created to allow for comparisons, whereby national actions taken in each of the Nordic countries can be assessed. A common ambition will be a clear benefit for the Nordic countries when coupled with a common monitoring of effects, an increased sharing of knowledge, a common effort to identify best practice, and increased scientific cooperation.

In the Plan of Action, it is concluded that the population of the Nordic countries far from follows the official recommendations on diet and physical activity, and there is a substantial and increasing prevalence of overweight and obesity among both adults and children. Therefore new common Nordic goals and visions on the development of diet, level of physical activity, and prevalence of overweight and obesity are set in the Nordic Plan of Action (box 1). 
Box 1. The goals and visions for improvement of the health of the Nordic population as stated in the Nordic Plan of Action

\section{Diet}

Goal 2011: The consumption of fruits and vegetables and of whole-grain bread/cereals has increased, and the intake of fat, especially saturated fat and trans fatty acids, and added sugar has been reduced. The intake of salt has been maintained or reduced, depending on the specific national context.

Vision 2021: A major part of the population is eating according to the Nordic Nutrition Recommendations. The current references for the vision are:

At least $70 \%$ of the population above 10 years has a daily intake of fruits and vegetables of at least $500 \mathrm{~g} /$ day. The average intake of children, 4-10 years, is at least $400 \mathrm{~g} /$ day.

The average dietary intake of the population meets the NNR on fat and saturated fat plus trans fatty acids (respectively, $30 \mathrm{E} \%$ and about $10 \mathrm{E} \%$, respectively), and at least $70 \%$ meets the NNR on fat (E\% between 25 and 35).

$80 \%$ or more meets the NNR recommendation on daily intake of added sugar (max. $10 \mathrm{E} \%)$.

$70 \%$ or more consumes fish or fish products, corresponding to a main dish twice a week.

At least $70 \%$ of the adult population has a daily intake of whole-grain bread/cereals corresponding to at least half of their daily intake of bread/cereals.

The average diet of adults meets the NNR recommendation on salt.

\section{Physical activity}

Goal 2011: The current trend, where an increasing proportion of adults and children are physically inactive, has been brought to a halt and at best reversed.

Vision 2021: At least $75 \%$ of the adult population is physically active (moderate intensity) for at least 30 minutes every day.

All children aged 1-12 and at least 85\% of children and youth aged 12-16 are physically active (moderate intensity) for at least 1 hour every day. 


\section{Overweight and obese}

Goal 2011: The continuing increase in the proportion of the overweight and obese has been stopped and at best reversed.

Vision 2021: The number of overweight and obese adults has been reduced by at least $30 \%$ from the present level.

The number of overweight and obese children and youngsters has been reduced by at least $50 \%$ from the present level

\section{Social inequality in health related to diet and physical activity}

Goal 2011: Existing differences between different social groups with regard to overweight, obesity, unhealthy diet, and physical inactivity have not deepened further and at best have been reduced.

Vision 2021: The variation between different social groups on meeting the defined objectives with regard to diet, physical activity, and overweight/obesity is at most $20 \%$.

As an important part of the Nordic Plan of Action, the Nordic Council of Ministers decided to develop a joint Nordic monitoring of diet, physical activity and overweight.

\subsection{Establishment of the working group on a common Nordic monitoring}

The responsibility of coordination of the work on developing and implementing the Nordic monitoring system was delegated to The Nordic Working Group on Diet, Food, and Toxicology (NKMT) under CSO-FJLS (Food) by the Nordic Council of Ministers. In 2007, NKMT endorsed the establishment of a Nordic working group on the development of a common Nordic monitoring, and the working group was primarily formed during autumn 2007.

\section{Aim}

The aim of the monitoring project is to suggest and validate a joint, low cost, Nordic monitoring system on diet, physical activity, and overweight. Data should be collected every second year, and in a representative way cover gender, predefined age groups (among children and adults), and social strata. 
The project consists of three parts:

- Part 1, 2007-2008: A description a joint Nordic method for collecting representative data, including description of sample size and characteristics, as well as practical considerations of the implementation of the monitoring system in the Nordic countries. In addition, plans for the validation studies will be approved and put forward to NKMT

- Part 2, 2009-2010: A validation of the suggested methods against an objective method (physical activity) or existing survey methods (diet). A network on child health will also be started with the objective to develop a network of monitoring child health in the Nordic countries, coordinate and harmonize central monitoring using the same measures, standards and way of analyses and third to compare the development in overweight in the Nordic countries

- Part 3, 2010-2013: First collection of data in all Nordic countries

Table 1. Time frame of the overall project (part 1-3)

\begin{tabular}{|c|c|c|c|c|}
\hline & $\begin{array}{l}\text { August } 2007 \text { - } \\
\text { January } 2008\end{array}$ & June 2008 & Summer 2008 & Autumn/winter 2008 \\
\hline Part 1 & $\begin{array}{l}\text { Project preparation } \\
\text { and } \\
\text { First meeting: } \\
\text { Discussion - Sample } \\
\text { size, practical } \\
\text { considerations } \\
\text { Electronic working } \\
\text { groups }\end{array}$ & $\begin{array}{l}\text { Second meeting: } \\
\text { Decision on which } \\
\text { questions and } \\
\text { measures to use } \\
\text { Decision on valida- } \\
\text { tion and budget for } \\
\text { each country }\end{array}$ & $\begin{array}{l}\text { Application to } \\
\text { Nordic Council } \\
\text { and Nordic } \\
\text { Innovation Centre } \\
\text { on validation } \\
\text { studies }\end{array}$ & $\begin{array}{l}\text { Detailed planning of } \\
\text { validation studies in } \\
\text { selected countries } \\
\text { NKMT meeting Aug/Sep } \\
2008 \\
\text { Workshops and meetings } \\
\text { on diet and physical } \\
\text { activity } \\
\text { Report to NKMT on part } 1 \\
\text { of project }\end{array}$ \\
\hline $\begin{array}{l}\text { Part } 2 \\
\text { and } 3\end{array}$ & \multicolumn{4}{|c|}{$\begin{array}{l}\text { Part } 2 \text { will be running in } 2009 \text { and } 2010 \text {. The validation studies will take place in 2009. A report } \\
\text { will be published on the results of the validation including a suggestion on the coming monitoring. } \\
\text { Part } 3 \text { can start in late } 2010 \text { and the first monitoring will be conducted in spring } 2011 \text { and the } \\
\text { second monitoring in } 2013 \text {. }\end{array}$} \\
\hline
\end{tabular}

The working group has considered to what extent the suggested indicators will be a sufficient measure for diet, physical activity (and overweight) in each country and to what extent the indicators provide comparable data among the Nordic countries. The working group has also discussed to what extent the indicators will be able to measure if the goals and visions set in the Nordic Plan of Action are reached or approached. The description of the joint Nordic method for collecting rep- 
resentative data suggested by the working group has been described in details previously (Fagt et al.., 2009).

The working group has discussed current surveys and research methods in the area of diet, physical activity and overweight. All the Nordic countries conduct large-scale nation-wide surveys that include data on diet, physical activity and anthropometry. Some countries have continuous surveys, others have surveys repeated every second, fifth or tenth year and others have surveys on more irregular basis. Some countries conduct surveys among all age groups, while others conduct surveys in specific age groups with years apart. It has not been considered possible to incorporate the future common Nordic monitoring in existing surveys because surveys in the Nordic countries are conducted irregularly and in different age groups. The working group has decided primarily to develop dietary indicator questions on basis of the validated indicator questions from the Norbagreen project and the dietary questions used in Sweden (Petkeviciene et al., 2009; Becker, 2009). Concerning physical activity the working group will develop indicator questions on basis of experiences with the IPAQ survey and other physical activity questionnaires (Craig et al.., 2003; http://www.ipaq.ki.se/ipaq.htm; Fogelholm et al.., 2006) and the working group has decided to develop a new questionnaire that fits the purpose of the Nordic monitoring system.

\subsubsection{Conclusion from part 1 of the project}

Since the Nordic Plan of Action emphasizes that the monitoring should be simple and at relatively low cost, it is considered necessary to conduct the survey as a telephone interview, as a telephone interview is easier and less expensive to conduct than face-to-face interviews.

The working group suggests 15 indicators of diet and 6 indicators of physical activity to be included in the questionnaire as well as self reported weight and height and background variables of participants (box 2). These indicators will cover important elements of diet and physical activity, but will not be able to provide information on all aspects of goals and visions of the Nordic Plan of Action. For instance the dietary indicators will only indirectly detect intake of nutrients and will not provide measures of intake of fatty acids or sugar (Vision 2021). Intake of nutrients needs to be measured through more in depth surveys, eg. national dietary surveys. 


\section{Diet}

- Which type of fat do you eat on bread

- Which type of fats do you use for frying, cooking, baking

- How many slices of bread do you eat during the day or week? (2-3 categories according to content of dietary fibre)

- How often (monthly, weekly, daily) do you eat fruit?

- How often (monthly, weekly, daily) do you eat vegetables?

- How often (monthly, weekly, daily) do you eat the following?

○ pommes frites/fried potatoes,

○ fish and seafood,

○ sausages as a main meal,

- candy and chocolate,

- cakes and biscuits,

- full fat cheese,

- soft drinks (carbonated/not carbonated, sugar sweetened),

- soft drinks( carbonated/not carbonated, light/artificial sweetened)

- fruit/vegetable juice

For questions with monthly, weekly or daily answering categories, these will include several frequencies (e.g. 1, 2, 3, 4 or more times).

\section{Physical activity}

For adults $(\geq 18 \mathrm{y})$ :

Occupational activity categorized into 4 labor-intensity categories.

The following questions should include all physical activity that is not part of occupational activity.

Vigorous physical activity that last for at least 20 min each time and specifically: a) days per week; and b) total time per week. Moderate-to-vigorous intensity physical activity that last for at least $10 \mathrm{~min}$ each time and at least $30 \mathrm{~min}$ in a day including both: a) days per week; and b) total time per week.

Daily screen time (TV and computer) at leisure time on average. Also, it is suggested that at least during validation of the questionnaire, a fifth question should be included and used to classify leisure-time physical activity into 4 categories. 
For adolescents (13-17 y):

Moderate-to-vigorous physical activity outside school (or working) hours:

- a) days per week with at least 60 min of activity;

- b) total time of moderate-to-vigorous physical activity per week;

- Daily screen time

For children (7-12 y) (the parent of a child (7-12 y is asked)

The questions would be the same as for the adolescents.

\section{Background variables}

Age, gender, education, family status, region and urbanization, self reported weight and height.

The working group emphasizes that the monitoring system can be used to evaluate the goals and visions of the Nordic Plan of Action, but suggests that the indicators may be supplemented by data from existing national surveys. As an example, the working group agrees that dietary indicators cannot measure the development of the intake of salt in the Nordic population and therefore suggests that a specific monitoring project at Nordic level is initiated to discuss the reduction of salt in prepared foods and the measurements needed for following the development. In the area of social inequality the working group has proposed new goals and visions for measuring if social inequality is to be reduced both in relation to diet, physical activity and overweight.

The working group suggests that four groups of education are used for analyzing education:

- Basic school (Short education)/<= 10 years of total education)

- Vocational education (11-13 y practical)

- Short higher education (13-14 y theoretical)

- Medium higher and long higher education (> 14 y theoretical)

For analysing family/household status, three groups are suggested: Single households, Household with couples (and children $>18$ y), Household with children. Region and urbanization (e.g. urban, semi-urban and rural): can be categorised from address of participant. It is considered that occupational status, employment status and household income can be omitted but of course would be valuable and can be included if the 
firm that is going to be responsible for the data collection (part 3 of the project) already include these variables as a standard. It is important to use standardised ways of measuring these variables in accordance with the Nordic Statistics standard.

The possibility of including ethnic groups in the survey has been discussed. Ethnic groups are very heterogeneous and have a higher proportion of people with short education and a high risk of overweight and obesity in combination with other health risks. Monitoring of their dietary habits and level of physical activity is therefore highly relevant. However many experts have concluded that these groups would need their own special surveys, focusing on their specific culture. ${ }^{1}$ Their proportion of the total population is less than $10 \%$ and in a country sample of 1,000 participants we will get approx 100 immigrants, but from different parts of the world, thus making conclusive results very difficult.

The sample should include 2,000 adults (18-65 y), 500 children (7$12 \mathrm{y}$ ) and 500 adolescents (13-17 y) in each country to ensure sufficient number of participants according to sex, age groups and socio-economic groups. The possibility to include a web based approach for answering the questionnaire need to be considered.

Regarding children the sampling might be a school-based approach, i.e. sampling based on school-classes. This would most likely increase participation, but would require a separate study design.

The monitoring system is suggested to start in 2011, which will serve as a baseline. If the monitoring is to be conducted every second year, the system will from 2013 and onward be able to monitor the development in dietary habits, physical activity and overweight.

The working group preliminary estimates the total costs of a future Nordic monitoring system are around 360000 - 400000 Euros or 2.7 - 3 million DKK every second year for one round of data collection.

After preparation of a more detailed project description, it is estimated that the costs for the monitoring will be 5.8 million DKK for first (baseline) data collection 2011 and second (follow up) data collection 2013, of which the project applies for 5 million DKK from NMR. The data collection will be conducted within the same two months in all five countries to take into account seasonal differences within the countries.

${ }^{1}$ Kumar \& Wandel. Symposium on "Eating behavior and physical activity in a multicultural perspective", Sixth Annual Conference of the International Society of Behavioral Nutrition and Physical Activity, Oslo, June 2007 
Regarding the Vision 2021 in the Nordic Plan of Action of 85\% of children aged 1-12 y are physically active for at least an hour every day, it must be emphasized that not all age groups are covered by a simple monitoring system, as monitoring small children below the age of $7 \mathrm{y}$ requires development of special methods to monitor their physical activity.

The working group has concluded that the indicator questions needed to be validated before inclusion in a Nordic monitoring system and has applied for funding of validation from Nordic Innovation and NKMT.

As part of the project the working group has contacted researchers in the area of monitoring childhood growth to establish a network of monitoring childhood growth in the Nordic countries. The aim of the network should be to coordinate and harmonize central monitoring using the same measures, standards and way of analyses within the Nordic Countries and thus compare the development in overweight in the Nordic countries.

In chapter 2 and 3 , the results from the validation studies on diet and physical activity will be described. 



\section{Validation - part 2 of the project}

Validity describes the degree to which a method measures what it is designed to measure. Validation can be done in different ways, but normally the method in question is validated against a reference method, e.g. relatively against another subjective method or against objective measures. When conducting a validation study information on the feasibility of the method will also be taken into consideration. If the aim of validation is to examine if the selected indicator questions work the same way in each country, then validation must be done against the same reference method in all countries (e.g. validation of diet indicators against 7 day weighed record and physical activity indicators against accelerometry). If the aim of the validation is to examine how the indicators work within a country, then the validation can be done with different reference methods (e.g. diet indicators against food records or $24 \mathrm{~h}$ recall).

Especially the dietary indicators need to be supplemented with information from the more detailed national dietary surveys, and therefore the working group finds it necessary to know how well the indicators reflect the diet as found in the national surveys.

In 2009, validation studies took place in Iceland, Denmark, Norway and Finland. Diet indicators were validated in Iceland and Denmark and physical activity indicators were validated in Iceland, Finland and Norway (part 2 of the project).

The working group found that it was not practical and financial possible to validate the indicators and to conduct repeatability studies in all five Nordic countries. Since related dietary questionnaires have been validated earlier in Norway, Finland and Sweden (Andersen et al., 2002; Petkeviciene et al., 2009; Persson \& Becker, 2002; Sepp et al., 2004) the working group found it unnecessary to conduct dietary validation studies in all countries. Some of the above mentioned validation studies have also included repeatability studies, but due to limited finances and time constraint this has not been conducted although documented consistency in results were relevant.

As it was decided to test the indicators on physical activity against accelerometers, it was practically feasible to make validation studies in 
Finland, Iceland and Norway, as the project group members from these countries had the experience of using accelerometers in studies on physical activity in humans.

\subsection{Validation of dietary indicators}

On basis of discussions in part 1 of the project, fifteen indicators of diet have been decided. The aim of part 2 was to test the feasibility and to validate this 15 item short Nordic food frequency questionnaire designed to estimate usual consumption of 15 selected indicator foods and beverages. The validation should examine the validity of the questionnaire on group level, the ability to rank individuals into different levels of intake and the ability to measure how well recommended intake is followed.

\subsubsection{Methods}

Validation of the short Nordic food frequency questionnaire (NFFQ) has been carried out in Iceland and Denmark. The NFFQ has been validated relatively against a reference method, a food record (FR) measuring the diet for 7 consecutive days as both Iceland and Denmark use food records in their national dietary surveys. The NFFQ was based on the Swedish indicator questionnaire comprising 11 foods or food categories and included additionally some questions on more food items, e.g. questions on milk, water, juice and sugared milk products (Iceland). The common questions for both Iceland and Denmark can be seen in box 2 .

The original Swedish FFQ (including additional questions) were translated into Icelandic and Danish and translated into English by a native English speaking person. Comparison of the English versions of the indicators showed only minor differences and the indicators were then back translated by native speaking person into Icelandic and Danish

\section{Denmark}

Prior to the validation study a pilot test among 17 participants were conducted in the summer of 2009. Minor changes of the questionnaire were done before the validation study started in August 2009. The study was approved by the Danish Data Protection Agency. As the study was a non-invasive study it didn't need approval by the Ethical Commitee of Copenhagen. The study was conducted in three clusters (Northern part of Jutland, the Island of Funen/southern part of Jutland and the Copenhagen area) in the three age groups: 7-12 y, 13-17 y and 18-65 y. With- 
in the clusters the Institute of Social Research draw a random sample from the civil registry. In all, 1,200 respondents were drawn, of which 1053 were eligible to be interviewed by telephone.

Participants were contacted by letter and invited to participate in the study. 788 respondents (74.8\%) agreed to participate in the study and were interviewed by telephone. At the end of the interview respondents were asked if they would register their diet for 7 consecutive days and if agreed, the interviewer would make an appointment to visit the respondent and give an oral and written instruction on how to fill in the 7 day food record.

The food record is structured according to meals and includes household measures and photos to estimate portion sizes. The food record is described in details elsewhere (Fagt et al., 2008). Adults and adolescents filled in the food record themselves and one of the parents (usually the mother) filled in records for children up till 10-12 y. After 7 days the interviewer returned and collected the completed food records. In all, 566 respondents (50.9\% of original sample) agreed to register their diet for 7 days and 532 respondents (50.5\%) delivered complete food records (table 2).

The food record data were calculated in GIES (General Intake Estimation System) based on www.foodcomp.dk, version 7 .

Age was calculated from date of birth and date of first day of recording dietary records. Some records missed recording dates and these were set to first of October 2009 (middle of data collection period).

\section{Iceland}

A pilot test among 16 children and adolescents was conducted in the spring of 2009, prior to the validation study. Minor changes were made in the questionnaire before the validation study was initiated in the autumn. The validation study was approved by The National Bioethics Committee (VSNb2009080014/03.7) and The Data Protection Authority (S4518/2009). The study was conducted in three clusters: Kópavogur, representing the Reykjavik Area; Selfoss, South-Iceland; and Húsavik, North-Iceland. Children (7-12 y) and adolescents (13-17 y) were included. The sample was selected on school basis, where different classes were selected for participation in each school. The aim was to include 200 children and adolescents (100 in each age group). Participants were contacted by an invitation letter $(n=417)$. Informed consent was obtained from 192 subjects or $46 \%$ of the eligible sample. In Iceland the same subjects were invited to validate both the dietary and physical activity part. The heavy work load introduced in the invitation letter might explain the relatively low participation rate. The respondents 
were interviewed by telephone (diet and physical activity questionnaires along with background information). Parents or caretakers of 712 y children were interviewed on behalf of their children. At the end of the phone call the interviewer made an appointment to either visit the respondent at home or meet him/her at school. The 7-12 year olds were visited at home while the 13-17 year olds were met at school.

Written and oral instructions were provided how to fill in the 7-day food record. The food record used in Iceland was open ended, not precoded as the Danish food record. Portion sizes were recorded either as household measures or by using a picture booklet to estimate portion sizes. The adolescents filled in the food record themselves but a parent or caretaker filled in records for children up to 10-12 y. The food records were collected by the interviewer and these were returned to the Unit for Nutrition Research for coding and analysis. In total, 134 completed the food record (table 2).

Data were entered into the nutrient calculating program, ICEFOOD. ICEFOOD was designed for the national dietary survey conducted in 2002. This program includes 452 food codes or recipes from the Icelandic Nutrition Council (now Public Health Institute), based on 1,148 food items from the National Nutrition Database, ISGEM.

Table 2. Number of participants with completed NFFQ and Food record (FR)

\begin{tabular}{|c|c|c|c|c|}
\hline & \multicolumn{2}{|c|}{ Iceland } & \multicolumn{2}{|c|}{ Denmark } \\
\hline & NFFQ & FR & NFFQ & FR \\
\hline Children & 109 & 92 & 267 & 201 \\
\hline Adolescents & 83 & 42 & 245 & 151 \\
\hline Adults & - & - & 276 & 180 \\
\hline Total & 192 & 134 & 788 & 532 \\
\hline
\end{tabular}

\subsubsection{Food coding}

Both the Icelandic and Danish NFFQ data has been converted to frequency per day or week (for bread slices per day or week) for all food groups and so were related food groups in the $7 \mathrm{~d}$ record, thus enabling comparison of frequencies by the two methods (average and distribution).

The original frequencies of the NFFQ were converted into frequencies per week by the following factors: Intake per month has been divided by 4 , intake per week has been used as it is, intake per day has been multiplied by 7 , intake less than once a month has been given the value 0,125 and non users was given the value zero.

For analyzing agreement and the ability to rank subjects, five frequency categories have been created: 
- 0-3 times per month

- 1-2 times per week

- 3-6 times per week

- 1-2 times a day

- 3 times a day or more

Categorisation into these five categories was applied to both NFFQ and FR data for relevant food groups.

The intakes of the food record have been calculated in two different ways as times per week for comparison with the NFFQ data. Firstly, eating occasions were counted as eaten/not eaten so e.g. if a participant ate 2 apples in one meal, this only counted as one eating occasion. Secondly, servings were taken into consideration and e.g. two apples in one meal were counted as two servings.

In both approaches minor intake from e.g. a slice of cucumber on bread or some berries on a cake have been excluded. Also composite dishes containing various amounts of vegetables were excluded. Food record data were coded into food groups which could be compared with food or food groups used in the NFFQ.

The calculation of FR data into either eating occasions or servings per week showed very different results according to the eating pattern of the specific food or food groups, as illustrated in table A1 (in appendix), where specific foods or food groups in the Danish study are shown.

As expected eating occasions result in lower frequencies than servings. But for some foods, e.g. bread, the usual eating pattern is to eat more than one slice of bread in one meal or eating occasion, which results in much higher values for serving than for eating occasions. On the other hand for fruits or vegetables the differences between values for eating occasions and servings are not that large. For water and milk the picture is very different with much higher values for water servings than occasions, while milk show smaller differences between eating occasions and servings. This might be due to different drinking patterns for milk and water, where it is more common to drink more glasses of water, when drinking water, while it is common to drink one glass of milk when drinking milk. On basis of these examples it is clear, that it is important to use knowledge on dietary habits in the different countries when interpreting results from the indicator questionnaires.

For evaluating the validity of the indicator questions (NFFQ), comparison of average intake measured as frequencies per week of foods (NFFQ) were compared to intake measured in grams by the food record (tables 3-5). Secondly, comparison of average intake measured as fre- 
quencies per week of foods from both methods were compared (tables 6-8). In this comparison, the values from FR were based on servings. Thirdly, the ability of the NFFQ to rank participants into the same category of frequency as FR was examined (tables 9-11). In this comparison, the values were also based on servings.

In appendices, tables of intake of selected macronutrients from food record in relation to frequencies from NFFQ are shown. These tables show the ability of the dietary indicators to estimate the intake of selected macronutrients.

The ability of the indicators to identify the number of participants following or not following dietary recommendations was evaluated by analyses of sensitivity and specificity. In this report, the sensitivity and specificity of the indicator questionnaire was evaluated according to recommendations for fruit and vegetables (tables 12-18).

Intakes assessed by NFFQ and food record were compared by using Wilcoxon signed rank test. Trend test was performed using Jonckheere Terpstra trend test between frequencies. Agreement between the two methods was assessed using cross classifications and proportion of individuals who were categorised in the same category were calculated. Spearman's rank correlation coefficients were applied.

\subsubsection{Results}

Tables 3-5 show that the frequencies obtained by the NFFQ are positively associated to the estimated intake in grams from the food records. For all age groups and for most food items is shown that with increasing frequencies in the food frequency questionnaire, there is an increasing intake as measured in grams in the food record.

However, tables 3-5 also show that some foods are seldom eaten of the majority of all age groups both in Iceland and in Denmark; this applies especially for sausages, but also fried potatoes and to a certain degree fish, and for the Icelandic children and adolescents as well for rye bread and wholemeal bread. For these food items almost all participants are belonging to the group with the lowest or the second lowest frequency.

To some extent statistical tests on Icelandic data show inconclusive results due to few subjects in the older age group.

The comparison of frequencies obtained by the NFFQ and frequencies of servings of the FR in tables 6-8, shows that the frequencies of most food items are significantly different. The NFFQ tends to underestimate consumption of wheat bread, vegetables, candy, chocolate, cakes 
and soft drinks, whereas overestimation by NFFQ is more scattered in some foods or some age groups.

Tables 9-11 show agreement between the two methods to rank the intake into same category. Most of the Spearman correlation coefficients between NFFQ and frequencies of servings of the FR are significant and the correlations are within the range between 0.33 and 0.71 , which is not lower than seen in comparable validation studies (Petkeviciene et al., 2009; Sepp et al., 2004). Some correlations are however relatively low (range -0.04-0.25) indicating a weak or no correlation between results from the two methods. The low correlation coefficients are mostly seen in children and adolescents; applying for sausages, fried potatoes, candy, cookies and cakes for both the Icelandic and Danish children and adolescents, while the Icelandic groups also have low correlation coefficient of wholemeal bread and full-fat cheese. The adult group in Denmark has low correlation coefficient for the sausages (table 11). The agreement into same category is between $23-83 \%$, which is similar to results from other studies ${ }^{2}$ and indicates that the NFFQ is able to rank participants according to low or high consumption of foods. Notice that some of the highest percentages of agreement are seen for the food items with low correlation coefficient, being the food items shown in table 3-5 where almost all participants are belonging to the group with the lowest or the second lowest frequency, which indicates low variability of intake of these food items.

The proportion of participants grossly misclassified into opposite category is low (0-6\%, data not shown), which supports the impression of the NFFQ being able to rank participants into high or low consumption.

Comparison between NFFQ and food record shows increasing intake of key macronutrients estimated by food record with increasing frequencies of relevant foods reported by NFFQ (results shown in appendix). In Denmark the intake of fruits shows significant negative trend with intake of energy from fat among children and adults, but no other foods or food groups show significant trend with intake of energy from fat. The intake of fruits shows significant negative trend with intake of energy from saturated fat in all age groups. The intake of fish shows significant negative trend with intake of energy from saturated fat

\footnotetext{
2 Several validation studies between the FFQ-method and a reference method have been conducted, but most validation studies are comparing intake of nutrients. The classification into same category when comparing FFQ and food record data in recent studies shows values between 20-37\% (Watson et al., 2009), 39-78\% (Masson et al., 2003), 34-72\% (Vereecken \& Maes, 2003).
} 
among adults. The intake of sugar sweetened soft drinks shows significant positive trend with energy from saturated fat among children and with intake of energy from sugar in all age groups. Also intake of candy and chocolate shows significant positive trend with energy from sugar among adults. The intake of fruits and vegetables show significant positive trend with intake of dietary fibre per $10 \mathrm{MJ}$ in all age groups. The intake of wheat bread shows significant negative trend with intake of dietary fibre per $10 \mathrm{MJ}$ in children and adults. The intake of fish, sugar sweetened soft drinks and water shows positive trend with dietary fibre in adults. For other foods the trend is borderline significant and for others there are no significant trend.

The Icelandic results among children and adolescents show for some foods or food groups a similar picture, but due to a lower participation rate than expected, especially among adolescents interpretation needs to be careful. Soft drinks, light are significant positively associated with intake of added sugar and negatively associated with percent of energy from fat and dietary fibre among Icelandic children. The intake of fruit and vegetable juice is negatively related to the intake of fat and saturated fat. The intake of candy is positively associated with intake of added sugar and also sugar sweetened milk products showed association with intake of added sugar (the question was included in the Icelandic questionnaire). The intake of vegetables is positively associated with intake of dietary fibre. In the Icelandic adolescents it is difficult to conclude on the results as the data lack power due to small number of participants. Some borderline significant positive trend between intake of white bread, fried potatoes/pommes frites, full fat cheese and percent of energy from total fat occur. There is a significant positive association between intake of sugar sweetened soft drink and intake of added sugar.

Especially fruits, vegetables, candy and chocolate, fish, wheat bread, sugar sweetened soft drinks and water are to a greater extent than other foods correlated to the macronutrients of interest. The results indicate a good agreement between some of the foods in the NFFQ and macronutrients of interest, but the agreement is better for children and adults than for adolescents.

The knowledge about these trends are taken into account in the development of a dietary quality index on basis of the frequencies by NFFQ which is useful in the future reporting of the results, making it simpler to estimate the overall quality of the diet as estimated by NFFQ. 


\section{Comparison between Denmark and Iceland}

Comparison of results between the countries reveals some difficulties for future interpretation. From tables 3-5 it is obvious that the same frequency obtained by the NFFQ corresponds to different amounts in grams in Iceland and Denmark within the same age group. For instance the frequency by NFFQ of vegetables among children is almost similar in Iceland and Denmark. On basis of the NFFQ it might be concluded that Icelandic and Danish adolescents eat vegetables with similar frequency (table 7), but on basis of table 4 it can be concluded that behind same frequencies from NFFQ, the corresponding amounts in grams are very different. This could be due to smaller portion sizes of vegetables in Iceland than Denmark. Regarding fish it is opposite, with almost same frequency of fish among children by NFFQ (table 6), but table 3 shows that the amounts eaten in grams measured by FR is much higher in Iceland than Denmark with same frequency by NFFQ. So when interpreting results between countries, it is necessary to have in mind culinary differences with respect to eating patterns and portion sizes.

With additional knowledge of usual portion and serving sizes as well as eating patterns in the Nordic countries and careful interpretation of results from the diet, the indicator questionnaires can be used for comparison between countries. However it might be necessary to follow and update knowledge of portion sizes in the Nordic countries, as portion sizes develop over time.

There are very few international validation studies, but results from the Norbagreen validation study revealed some of the same issues concerning culinary differences making comparison between countries difficult (Petkeviciene et al., 2009). 
Table 3. Mean intake, gram per week, from food record in children 7-12 y (numbers with observed intake in brackets) ranked in relation to frequencies from NFFQ

Country

Iceland

\begin{tabular}{|c|c|c|c|c|c|c|}
\hline & Per month & Per w & & Per & & \\
\hline $\begin{array}{l}\text { Food record, } \\
\text { gram per week, }(\mathrm{n})\end{array}$ & $\begin{array}{r}0-3 \\
\text { times }\end{array}$ & $\begin{array}{r}1-2 \\
\text { times }\end{array}$ & $\begin{array}{r}3-6 \\
\text { times }\end{array}$ & $\begin{array}{r}1-2 \\
\text { times }\end{array}$ & $\begin{array}{r}3 \\
\text { times or } \\
\text { more }\end{array}$ & p-value* \\
\hline Rye bread, gram/week & $8(45)$ & $42(40)$ & $146(5)$ & 60 (1) & 460 (1) & $<0.001$ \\
\hline Wholemeal bread, gram/week & $29(58)$ & 25 (12) & $33(6)$ & 11 (11) & $10(5)$ & 0.410 \\
\hline Wheat bread, gram/week & $771(8)$ & $462(8)$ & $570(13)$ & $621(46)$ & 755 (17) & 0.021 \\
\hline Vegetables, gram/week & $350(2)$ & $127(10)$ & $230(15)$ & $322(53)$ & $693(12)$ & $<0.001$ \\
\hline Fruits, gram/week & & $263(2)$ & $637(11)$ & $820(69)$ & $1109(10)$ & 0.008 \\
\hline Pommes frites/fried potatoes, gram/week & $28(76)$ & $33(16)$ & & - & - & 0.544 \\
\hline Fish, gram/week & $86(9)$ & $220(60)$ & $298(23)$ & - & - & 0.006 \\
\hline Sausages, gram/week & $76(58)$ & $84(33)$ & $50(1)$ & - & - & 0.710 \\
\hline Candy/chocolate gram/week & $90(5)$ & $154(78)$ & 178 (9) & - & - & 0.180 \\
\hline Cookies/cake, gram/week & $246(10)$ & $295(35)$ & $347(35)$ & $393(12)$ & - & 0.100 \\
\hline Fulfat cheese, gram/week & $63(20)$ & $71(10)$ & $67(24)$ & $87(32)$ & $74(6)$ & 0.065 \\
\hline Soft drinks, light, gram/week & $110(53)$ & $106(24)$ & $770(12)$ & $283(3)$ & - & 0.003 \\
\hline Soft drinks, sugar sweetened, gram/week & $933(42)$ & $1210(35)$ & $1461(10)$ & $1193(5)$ & - & 0.051 \\
\hline Fruit, vegetable juice, gram/week & $420(18)$ & $418(18)$ & $590(25)$ & $946(30)$ & - & 0.006 \\
\hline Water, gram/week & & & $1600(2)$ & $1708(19)$ & $2832(61)$ & $<0.001$ \\
\hline Milk, gram/week & $1034(7)$ & $617(6)$ & $1576(7)$ & 1594 (54) & $2201(21)$ & 0.001 \\
\hline
\end{tabular}

*Jonckheere-Terpstra test for trend
Denmark

201

\begin{tabular}{|c|c|c|c|c|c|}
\hline \multirow{2}{*}{$\begin{array}{r}\text { Per month } \\
0-3 \\
\text { times }\end{array}$} & \multicolumn{2}{|c|}{ Per week } & \multicolumn{2}{|c|}{ Per day } & \multirow[b]{2}{*}{$p$-value } \\
\hline & $\begin{array}{r}1-2 \\
\text { times }\end{array}$ & $\begin{array}{r}3-6 \\
\text { times }\end{array}$ & $\begin{array}{r}1-2 \\
\text { times }\end{array}$ & $\begin{array}{r}3 \\
\text { times or } \\
\text { more }\end{array}$ & \\
\hline $100(3)$ & $80(2)$ & $473(5)$ & $381(138)$ & $546(53)$ & $<0.001$ \\
\hline $158(38)$ & $230(29)$ & $302(43)$ & $287(82)$ & $400(9)$ & $<0.001$ \\
\hline $167(47)$ & $223(61)$ & $263(37)$ & $393(49)$ & $521(7)$ & $<0.001$ \\
\hline $213(2)$ & $309(12)$ & $408(23)$ & $812(147)$ & $949(17)$ & $<0.001$ \\
\hline $0(1)$ & $261(4)$ & $497(19)$ & $1018(131)$ & $1749(46)$ & $<0.001$ \\
\hline 110 (139) & $192(54)$ & $186(8)$ & & - & $<0.001$ \\
\hline $42(48)$ & $91(101)$ & $138(38)$ & $131(14)$ & - & $<0.001$ \\
\hline $29(187)$ & $10(14)$ & & & - & $<0.001$ \\
\hline $59(12)$ & $128(135)$ & $140(33)$ & $168(19)$ & $153(2)$ & $<0.001$ \\
\hline $133(42)$ & 174 (123) & $275(23)$ & $448(13)$ & - & $<0.001$ \\
\hline $7(89)$ & $32(43)$ & $49(46)$ & $72(22)$ & $64(1)$ & $<0.001$ \\
\hline $183(105)$ & $483(62)$ & $775(8)$ & 2008 (24) & $8000(2)$ & $<0.001$ \\
\hline $1098(88)$ & $1752(84)$ & $2393(14)$ & $2317(14)$ & $3480(1)$ & $<0.001$ \\
\hline $188(66)$ & $450(72)$ & 920 (21) & 1335 (42) & - & \\
\hline $0(1)$ & $1200(2)$ & $200(2)$ & 2702 (33) & 4788 (163) & $<0.001$ \\
\hline $500(24)$ & 1014 (11) & $1444(9)$ & $2308(120)$ & $3491(37)$ & \\
\hline
\end{tabular}


Table 4. Mean intake, gram per week, from food record in adolescents 13-17 y (numbers with observed intake in brackets) ranked in relation to frequencies from NFFQ

Country

Iceland

\begin{tabular}{|c|c|c|c|c|c|c|}
\hline \multirow[b]{2}{*}{$\begin{array}{l}\text { Food record, } \\
\text { gram per week (n) }\end{array}$} & \multirow{2}{*}{$\begin{array}{r}\text { Per month } \\
0-3 \\
\text { times }\end{array}$} & \multicolumn{2}{|c|}{ Per week } & \multicolumn{2}{|c|}{ Per day } & \multirow[b]{2}{*}{ p-value* } \\
\hline & & $\begin{array}{r}1-2 \\
\text { times }\end{array}$ & $\begin{array}{r}3-6 \\
\text { times }\end{array}$ & $\begin{array}{r}1-2 \\
\text { times }\end{array}$ & $\begin{array}{r}3 \\
\text { times or } \\
\text { more }\end{array}$ & \\
\hline Rye bread, gram/week & $15(25)$ & $17(16)$ & 80 (1) & - & - & 0.307 \\
\hline Wholemeal bread, gram/week & $25(30)$ & $40(5)$ & 55 (3) & $0(2)$ & $50(2)$ & 0.280 \\
\hline Wheat bread, gram/week & $678(3)$ & 409 (3) & $522(8)$ & $607(19)$ & $824(6)$ & 0.088 \\
\hline Vegetables, gram/week & - & 206 (3) & 219 (6) & $280(32)$ & 695 (1) & 0.501 \\
\hline Fruits, gram/week & - & 381 (3) & 465 (6) & $828(23)$ & $826(10)$ & 0.047 \\
\hline Pommes frites/fried potatoes, gram/week & 27 (37) & $110(5)$ & - & - & - & 0.024 \\
\hline Fish, gram/week & $184(4)$ & $199(29)$ & 253 (9) & - & - & 0.433 \\
\hline Sausages, gram/week & $2(29)$ & $9(17)$ & $21(2)$ & & & $<0.001$ \\
\hline Candy/chocolate gram/week & $62(5)$ & $130(31)$ & $227(5)$ & 420 (1) & - & 0.237 \\
\hline Cookies/cake, gram/week & $217(14)$ & $244(17)$ & 461 (9) & $492(2)$ & . & 0.031 \\
\hline Fulfat cheese, gram/week & $85(6)$ & $92(4)$ & $53(10)$ & 70 (17) & $102(5)$ & 0.625 \\
\hline Soft drinks, light, gram/week & $160(14)$ & $335(10)$ & 356 (9) & $630(5)$ & & 0.621 \\
\hline Soft drinks, sugar sweetened, gram/week & $463(16)$ & $1037(16)$ & $2863(6)$ & 465 (2) & - & $<0.001$ \\
\hline Fruit, vegetable juice, gram/week & $300(4)$ & 301 (11) & $539(15)$ & 685 (9) & $1700(2)$ & 0.069 \\
\hline Water, gram/week & & & & $1665(8)$ & 3506 (26) & 0.264 \\
\hline Milk, gram/week & 975 (2) & 100 (1) & 650 (4) & $1610(25)$ & $1920(9)$ & 0.006 \\
\hline
\end{tabular}

(1)

*Jonckheere-Terpstra test for trend

Denmark

\begin{tabular}{|c|c|c|c|c|c|}
\hline \multirow{2}{*}{$\begin{array}{r}\text { Per month } \\
0-3 \\
\text { times }\end{array}$} & \multicolumn{2}{|c|}{ Per week } & \multicolumn{2}{|c|}{ Per day } & \multirow[b]{2}{*}{ p-value } \\
\hline & $\begin{array}{r}1-2 \\
\text { times }\end{array}$ & $\begin{array}{r}3-6 \\
\text { times }\end{array}$ & $\begin{array}{r}1-2 \\
\text { times }\end{array}$ & $\begin{array}{r}3 \\
\text { times or } \\
\text { more }\end{array}$ & \\
\hline 95 (7) & $160(21)$ & $209(21)$ & $282(79)$ & $533(40)$ & $<0.001$ \\
\hline $168(25)$ & 196 (15) & $231(27)$ & $321(63)$ & 485 (21) & $<0.001$ \\
\hline 185 (31) & 245 (35) & $338(28)$ & 410 (49) & $723(8)$ & $<0.001$ \\
\hline 66 (5) & 279 (14) & 316 (18) & 729 (106) & 589 (8) & $<0.001$ \\
\hline $78(4)$ & 258 (14) & 464 (11) & $1012(77)$ & $1582(45)$ & $<0.001$ \\
\hline 146 (89) & 156 (49) & $215(13)$ & - & - & 0.003 \\
\hline $64(40)$ & $78(88)$ & 115 (16) & 86 (6) & $0(1)$ & 0.083 \\
\hline 19 (144) & $19(7)$ & & & - & 0.482 \\
\hline $39(5)$ & $114(82)$ & $184(49)$ & $170(15)$ & - & $<0.001$ \\
\hline 139 (44) & $214(75)$ & $219(23)$ & 260 (9) & - & $<0.001$ \\
\hline $5(90)$ & 22 (24) & $53(23)$ & 72 (14) & - & $<0.001$ \\
\hline $245(72)$ & $582(39)$ & $925(20)$ & 3076 (16) & 675 (4) & $<0.001$ \\
\hline 1439 (46) & $1680(72)$ & $2390(21)$ & 3350 (10) & $1100(2)$ & $<0.001$ \\
\hline $178(43)$ & 254 (49) & $658(30)$ & $1276(28)$ & 3600 (1) & $<0.001$ \\
\hline 200 (1) & 500 (2) & $0(1)$ & 2661 (27) & $5250(120)$ & $<0.001$ \\
\hline $589(23)$ & 744 (13) & $1764(7)$ & 2317 (78) & 3486 (30) & $<0.001$ \\
\hline
\end{tabular}


Table 5. Mean intake gram per week from food record in adults 18-65 y (numbers with observed intake in brackets) ranked in relation to frequencies from NFFQ, Denmark Country

Denmark

180

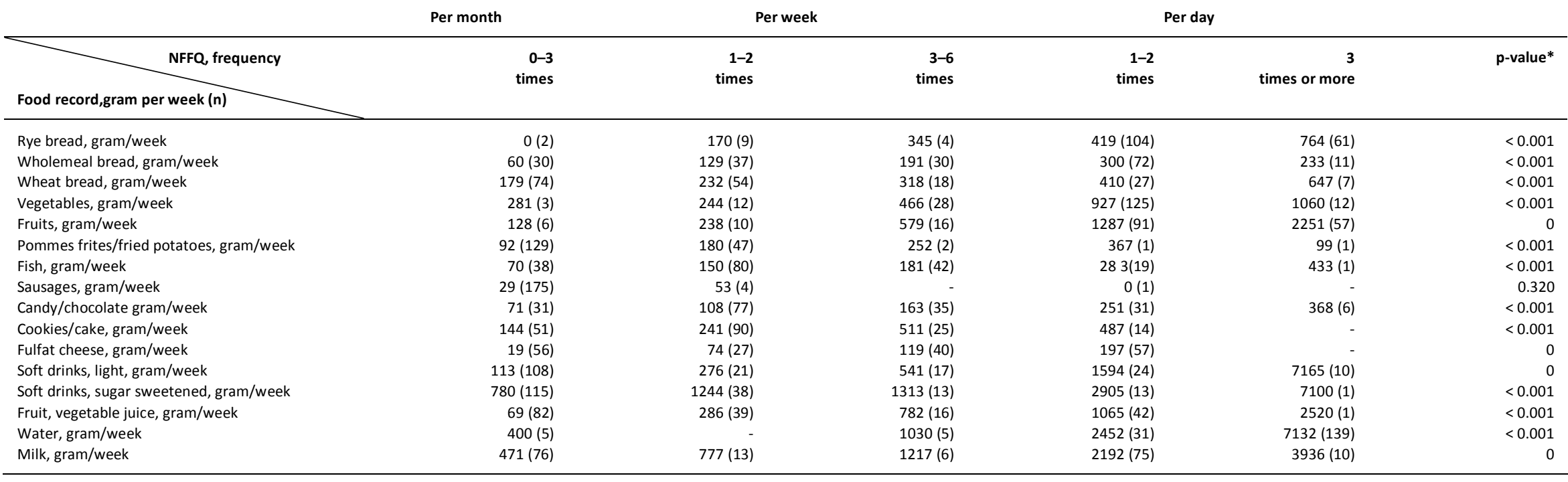

*Jonckheere-Terpstra test for trend 
Table 6. Average frequency per week in intake of different foods in children 7-12 y (NFFQ and food record (based on servings))

\begin{tabular}{|c|c|c|c|c|c|}
\hline \multirow{3}{*}{$\begin{array}{l}\text { Country } \\
n\end{array}$} & \multicolumn{5}{|c|}{ Iceland } \\
\hline & \multicolumn{5}{|c|}{92} \\
\hline & NFFQ & SD & FR & SD & p-value* \\
\hline Rye bread, slices & 1.1 & 2.4 & 0.9 & 2.9 & 0.302 \\
\hline Wholemeal bread, slices & 3.0 & 6.2 & 1.2 & 1.2 & 0.100 \\
\hline Wheat bread, slices & 12.1 & 12.5 & 12.2 & 6.2 & 0.146 \\
\hline Vegetables & 9,6 & 6.6 & 5.4 & 4.3 & $<0.001$ \\
\hline Fruits & 11,1 & 5.3 & 8.4 & 6.3 & $<0.001$ \\
\hline Pommes frites, fried potatoes & 0,5 & 0.4 & 0.5 & 0.8 & 0.963 \\
\hline Fish & 2.0 & 0.9 & 1.8 & 1.3 & 0.218 \\
\hline Sausages & 0.7 & 0.6 & 0.6 & 0.8 & 0.414 \\
\hline Candy, chocolate & 1.5 & 0.8 & 2.3 & 1.9 & $<0.001$ \\
\hline Cookies. Cakes & 3.0 & 2.3 & 5.2 & 2.9 & $<0.001$ \\
\hline Fulfat cheese & 5.9 & 6.0 & 3.4 & 2.8 & $<0.001$ \\
\hline Soft drinks, light & 1.2 & 2.1 & 0.9 & 1.7 & 0.050 \\
\hline Soft drinks, sugar sweetened & 1.4 & 2.1 & 3.9 & 2.9 & $<0.001$ \\
\hline Fruit, vegetable juice & 4.2 & 4.1 & 2.6 & 3.3 & 0.001 \\
\hline Water & 22.1 & 7.7 & 10.4 & 6.4 & $<0.001$ \\
\hline Milk & 11.9 & 7.9 & 8.3 & 4.0 & $<0.001$ \\
\hline
\end{tabular}

\begin{tabular}{rrrrr}
\hline \multicolumn{5}{c}{ Denmark } \\
\multicolumn{5}{c}{ 201 } \\
NFFQ & SD & FR & SD & p-value* \\
\hline 14.6 & 6.7 & 17.4 & 9.9 & 0.00 \\
6.7 & 7.2 & 6.6 & 6.1 & 0.957 \\
4.4 & 5.8 & 8.6 & 7.1 & $<0.001$ \\
10.1 & 6.2 & 14.8 & 10.1 & $<0.001$ \\
13.3 & 6.7 & 12.0 & 9.5 & 0.001 \\
0.7 & 0.7 & 1.3 & 1.3 & $<0.001$ \\
2.0 & 6.8 & 2.9 & 3.4 & 0.002 \\
0.3 & 0.4 & 0.4 & 1.1 & 0.355 \\
2.5 & 3.2 & 5.0 & 5.0 & $<0.001$ \\
1.9 & 2.0 & 6.2 & 7.3 & $<0.001$ \\
2.2 & 3.0 & 1.8 & 3.0 & 0.172 \\
2.0 & 4.1 & 3.0 & 7.2 & 0.008 \\
1.7 & 2.9 & 4.8 & 4.2 & $<0.001$ \\
2.5 & 2.9 & 3.3 & 4.0 & 0.002 \\
23.1 & 6.8 & 21.7 & 13.4 & 0.009 \\
11.1 & 7.6 & 11.3 & 8.3 & 0.993 \\
\hline
\end{tabular}

*Wilcoxon signed rank test

Table 7. Average frequency per week in intake of different foods in adolescents 13-17 y (NFFQ and food record (based on servings))

\section{Country}

\begin{tabular}{lrrrrr} 
& NFFQ & SD & FR & SD & p-value* \\
\hline Rye bread, slices & 0.6 & 0.8 & 0.3 & 0.6 & 0.056 \\
Wholemeal bread, slices & 2.1 & 5.7 & 0.8 & 2.1 & 0.325 \\
Wheat bread, slices & 11.4 & 9.1 & 9.1 & 5.9 & 0.492 \\
Vegetables & 8.1 & 4.9 & 2.7 & 2.2 & $<0.001$ \\
Fruits & 11.6 & 7.9 & 6.3 & 4.9 & $<0.001$ \\
Pommes frites, fried potatoes & 0.4 & 0.4 & 0.5 & 0.6 & 0.590 \\
Fish & 1.8 & 1.0 & 1.6 & 1.3 & 0.246 \\
Sausages & 0.8 & 0.8 & 0.6 & 1.0 & 0.058 \\
Candy, chocolate & 2.1 & 2.8 & 2.1 & 2.9 & 0.824 \\
Cookies. Cakes & 2.1 & 2.5 & 4.6 & 4.2 & $<0.001$ \\
Fulfat cheese & 8.5 & 8.3 & 3.2 & 2.3 & 0.001 \\
Soft drinks, light & 2.2 & 2.4 & 0.9 & 2.3 & 0.008 \\
Soft drinks, sugar sweetened & 1.9 & 2.5 & 2.9 & 3.0 & 0.003 \\
Fruit, vegetable juice & 4.9 & 5.1 & 2.2 & 3.2 & $<0.001$ \\
Water & 22.0 & 6.6 & 9.0 & 7.0 & $<0.001$ \\
Milk & 12.2 & 7.7 & 7.1 & 3.9 & $<0.001$
\end{tabular}

Denmark

\begin{tabular}{rrrrr} 
NFFQ & SD & FR & SD & p-value* \\
\hline 14.5 & 10.3 & 13.7 & 11.0 & 0.676 \\
8.9 & 8.5 & 7.3 & 8.4 & 0.005 \\
6.0 & 7.4 & 10.8 & 9.3 & $<0.001$ \\
8.9 & 5.8 & 10.4 & 9.7 & 0.160 \\
13.5 & 9.2 & 11.1 & 12.1 & $<0.001$ \\
0.9 & 0.9 & 1.4 & 1.6 & 0.002 \\
1.8 & 2.3 & 2.1 & 2.6 & 0.005 \\
0.2 & 0.3 & 0.3 & 0.9 & 0.001 \\
2.9 & 2.5 & 6.0 & 6.6 & $<0.001$ \\
1.9 & 2.3 & 4.9 & 6.9 & $<0.001$ \\
1.6 & 2.5 & 1.3 & 2.6 & 0.221 \\
2.7 & 5.1 & 3.7 & 10.3 & 0.413 \\
2.0 & 3.0 & 6.4 & 7.1 & $<0.001$ \\
3.0 & 3.7 & 3.0 & 4.3 & 0.585 \\
23.4 & 7.1 & 23.3 & 17.7 & 0.148 \\
10.7 & 9.1 & 10.9 & 8.7 & 0.411
\end{tabular}

*Wilcoxon signed rank test 
Table 8. Average frequency per week in intake of different foods in adults 18-65 y (NFFQ and food record (based on servings))

\begin{tabular}{lrrrrr}
\hline Country & & & Denmark & & \\
$\mathbf{n}$ & & & & \\
& & & & \\
& NFFQ & SD & FR & SD & p-value* \\
\hline Rye bread, slices & 16.0 & 9.3 & 20.6 & 13.6 & $<0.001$ \\
Wholemeal bread, slices & 6.6 & 6.9 & 5.1 & 6.2 & 0.039 \\
Wheat bread, slices & 3.3 & 6.9 & 8.5 & 7.4 & $<0.001$ \\
Vegetables & 9.6 & 6.4 & 13.8 & 10.5 & 0.00 \\
Fruits & 14.1 & 9.3 & 15.9 & 15.0 & 0.521 \\
Pommes frites, fried potatoes & 0.7 & 1.7 & 1.1 & 1.2 & $<0.001$ \\
Fish & 2.4 & 2.6 & 4.4 & 4.7 & $<0.001$ \\
Sausages & 0.2 & 0.6 & 0.4 & 1.6 & 0.014 \\
Candy, chocolate & 3.6 & 4.8 & 6.8 & 9.4 & $<0.001$ \\
Cookies. Cakes & 1.8 & 1.8 & 6.4 & 7.4 & $<0.001$ \\
Fulfat cheese & 3.6 & 3.5 & 6.0 & 6.5 & $<0.001$ \\
Soft drinks, light & 3.0 & 6.1 & 3.8 & 10.6 & 0.872 \\
Soft drinks, sugar sweetened & 1.4 & 3.1 & 3.4 & 5.8 & $<0.001$ \\
Fruit, vegetable juice & 2.7 & 3.8 & 2.4 & 3.7 & 0.143 \\
Water & 22.6 & 7.9 & 29.8 & 22.3 & $<0.001$ \\
Milk & 5.5 & 7.1 & 12.2 & 13.4 & $<0.001$ \\
\hline
\end{tabular}

*Wilcoxon signed rank test

Table 9. Agreement between NFFQ and Food record (frequencies per week*) in children 7-12 y

Country Iceland Denmark

$92 \quad 201$

\begin{tabular}{lcccc} 
& \% same category & Spearman & \% same category & Spearman \\
\hline Rye bread, slices & 38.0 & 0.42 & 63,2 & 0.37 \\
Wholemeal bread, slices & 42.4 & 0.11 & 49.3 & 0.25 \\
Wheat bread, slices & 38.0 & 0.27 & 26.4 & 0.42 \\
Vegetables & 33.7 & 0.53 & 52.7 & 0.39 \\
Fruits & 27.2 & 0.36 & 47.8 & 0.54 \\
Pommes frites, fried potatoes & 64.1 & 0.24 & 39.8 & 0.26 \\
Fish & 55.4 & 0.35 & 39.8 & 0.34 \\
Sausages & 52.7 & 0.07 & 73.6 & 0.12 \\
Candy, chocolate & 42.4 & 0.23 & 35.9 & 0.27 \\
Cookies. Cakes & 31.5 & 0.17 & 23.4 & 0.24 \\
Fulfat cheese & 29.3 & 0.33 & 49.3 & 0.46 \\
Soft drinks, light & 59.8 & 0.49 & 26.4 & 0.54 \\
Soft drinks, sugar sweetened & 20.7 & 0.23 & 52.3 & 0.34 \\
Fruit, vegetable juice & 39.1 & 0.40 & 44.3 & 0.59 \\
Water & 28.9 & 0.52 & 52.7 & 0.45 \\
Milk & 43.5 & 0.46 & 54.7 & 0.61 \\
\hline
\end{tabular}

*Frequencies based on servings in FR 


\begin{tabular}{|c|c|c|c|c|}
\hline \multirow{3}{*}{$\mathbf{n}$} & \multicolumn{2}{|c|}{ Iceland } & \multicolumn{2}{|c|}{ Denmark } \\
\hline & \multicolumn{2}{|c|}{43} & \multicolumn{2}{|c|}{151} \\
\hline & $\%$ same category & Spearman & $\%$ same category & Spearman \\
\hline Rye bread, slices & 53.5 & 0.04 & 47.0 & 0.41 \\
\hline Wholemeal bread, slices & 65.1 & 0.17 & 30.5 & 0.39 \\
\hline Wheat bread, slices & 41.9 & 0.38 & 31.1 & 0.40 \\
\hline Vegetables & 11.6 & 0.27 & 41.7 & 0.40 \\
\hline Fruits & 27.9 & 0.39 & 34.4 & 0.51 \\
\hline Pommes frites, fried potatoes & 65.1 & 0.30 & 39.7 & 0.11 \\
\hline Fish & 39.5 & 0.31 & 37.1 & 0.17 \\
\hline Sausages & 55.8 & 0.34 & 83.4 & 0.07 \\
\hline Candy, chocolate & 37.3 & 0.14 & 22.5 & 0.22 \\
\hline Cookies, Cakes & 25.6 & 0.34 & 28.5 & 0.18 \\
\hline Fulfat cheese & 9.3 & -0.04 & 60.3 & 0.52 \\
\hline Soft drinks, light & 39.5 & 0.29 & 23.8 & 0.42 \\
\hline Soft drinks, sugar sweetened & 41.9 & 0.53 & 48.3 & 0.34 \\
\hline Fruit, vegetable juice & 26.8 & 0.37 & 43.1 & 0.54 \\
\hline Water & 14.3 & 0.21 & 51.7 & 0.39 \\
\hline Milk & 42.9 & 0.39 & 46.4 & 0.61 \\
\hline
\end{tabular}

*Frequencies based on servings in FR

Table 11. Agreement between NFFQ and Food record (frequencies per week*) in adults 18-65 y Country

Denmark

n

180

\begin{tabular}{lcc} 
& \% same category & Spearman \\
\hline Rye bread, slices & 60.0 & 0.62 \\
Wholemeal bread, slices & 33.3 & 0.37 \\
Wheat bread, slices & 25.1 & 0.45 \\
Vegetables & 52.2 & 0.47 \\
Fruits & 48.9 & 0.65 \\
Pommes frites, fried potatoes & 48.9 & 0.36 \\
Fish & 37.2 & 0.41 \\
Sausages & 83.9 & 0.25 \\
Candy, chocolate & 39.4 & 0.50 \\
Cookies, Cakes & 25.0 & 0.44 \\
Fulfat cheese & 51.1 & 0.71 \\
Soft drinks, light & 49.5 & 0.54 \\
Soft drinks, sugar sweetened & 60.5 & 0.43 \\
Fruit, vegetable juice & 58.9 & 0.67 \\
Water & 65.6 & 0.58 \\
Milk & 45.6 & 0.48 \\
\hline
\end{tabular}

*Frequencies based on servings in FR

\section{Specificity and sensitivity of the dietary indicators}

The dietary indicators should be able to identify participants following dietary recommendations as the Nordic Plan of Action has specific goals for the improvement of the diet in the Nordic Countries (see table 1). In the validation study, the indicators are evaluated for their specificity and sensitivity according to recommendations for fruit and vegetables. 
Specificity is defined as the number of participants not following recommendations by both methods as a percentage of those actually not following the recommendations according to the food record.

Sensitivity regards the number of participants following recommendations by both methods as a percentage of those actually following the recommendations according to the food record.

Good specificity and poor sensitivity means that the NFFQ measures most participants not following recommendations, although several following recommendations are falsely detected.

\begin{tabular}{|c|c|c|}
\hline & Specificity & Sensitivity \\
\hline & \multicolumn{2}{|c|}{ According to Food record "truth" } \\
\hline & $\begin{array}{l}\text { Unhealthy } \\
\text { (do not follow recommendations) }\end{array}$ & $\begin{array}{c}\text { Healthy } \\
\text { (follow recommendations) }\end{array}$ \\
\hline NFFQ Do not follow recommendation & True positive $A$ & False positive $B$ \\
\hline NFFQ follow recommendation & False negative $\mathrm{C}$ & True negative $D$ \\
\hline
\end{tabular}

Specificity: $A /(A+C)$ true positive/(true positive+false negative)

Sensitivity: $D /(D+B)$ true negative /(true negative+false positive)

\section{Denmark}

Fruit and vegetables (recommended intake $400 \mathrm{~g}$ and above for $4-9 \mathrm{y}$, $600 \mathrm{~g}$ and above for 10-65 y. One unit of fruit or vegetables is $100 \mathrm{~g}$ ). The frequencies of the NFFQ were calculated into gram per week by multiplying the frequency per week with $100 \mathrm{~g}$. The calculated amount from NFFQ was compared to amounts by FR.

Table 13. Number of participants following recommended intake of fruits and vegetables

\begin{tabular}{lcc}
\hline & $\begin{array}{c}\text { Do not follow recommenda- } \\
\text { tion according to FR }\end{array}$ & $\begin{array}{c}\text { Follow recommenda- } \\
\text { tion according to FR }\end{array}$ \\
\hline $\begin{array}{l}\text { Do not follow recommendation according to } \\
\text { NFFQ } \\
\text { Follow recommendation according to NFFQ }\end{array}$ & 395 & 47 \\
\hline
\end{tabular}

Specificity $89 \%$

Sensitivity $47 \%$

The specificity for intake of fruits and vegetables is high (89\%), as out of $444(395+49)$ reporting less than recommended intake of fruit and vegetables by food records, 395 of these also reported this level of intake by NFFQ. The sensitivity was lower $(47 \%)$ as out of $88(47+41)$ reporting adequate intake of fruit and vegetables by food records, only 41 of these also reported following the recommendations by NFFQ. 
Vegetables (recommended intake $200 \mathrm{~g}$ and above for 4-9 $\mathrm{y}, 300 \mathrm{~g}$ and above for $10-65 \mathrm{y}$ ).

Table 14. Number of participants following recommended intake of vegetables

\begin{tabular}{lcc}
\hline & $\begin{array}{c}\text { Do not follow recommenda- } \\
\text { tion according to FR }\end{array}$ & $\begin{array}{c}\text { Follow recommenda- } \\
\text { tion according to FR }\end{array}$ \\
\hline $\begin{array}{l}\text { Do not follow recommendation according to } \\
\text { NFFQ }\end{array}$ & 418 & 36 \\
Follow recommendation according to NFFQ & 53 & 25 \\
\hline
\end{tabular}

Specificity $89 \%$

Sensitivity $41 \%$

The specificity for intake of vegetables is high (89\%), as out of 471 $(418+53)$ reporting less than recommended intake of vegetables by food records, 418 of these also reported this level of intake by NFFQ. The sensitivity was lower $(41 \%)$ as out of $61(36+25)$ reporting adequate intake of vegetables by food records, only 25 of these also reported following the recommendations by NFFQ.

Fruit (recommended intake $200 \mathrm{~g}$ and above for $4-9 \mathrm{y}, 300 \mathrm{~g}$ and above for $10-65 \mathrm{y})$.

Table 15. Number of participants following recommended intake of fruits

\begin{tabular}{lcc}
\hline & $\begin{array}{c}\text { Do not follow recommenda- } \\
\text { tion according to FR }\end{array}$ & $\begin{array}{c}\text { Follow recommenda- } \\
\text { tion according to FR }\end{array}$ \\
\hline $\begin{array}{l}\text { Do not follow recommendation according to } \\
\text { NFFQ } \\
\text { Follow recommendation according to NFFQ }\end{array}$ & 287 & 50 \\
\hline
\end{tabular}

Specificity $74 \%$

Sensitivity $65 \%$

The specificity for intake of fruits is relatively high (74\%), as out of 389 $(287+102)$ reporting less than recommended intake of fruits by food records, 287 of these also reported this level of intake by NFFQ. The sensitivity is relatively high $(65 \%)$ as out of $143(50+93)$ reporting adequate intake of fruits by food records, 93 of these also reported following the recommendations by NFFQ.

\section{Iceland}

Fruit and vegetable intake among Icelandic children and adolescents is exceptionally low, making specificity and sensitivity assessing the compliance to the recommendations on fruit and vegetable intake hard. The number of subjects in the age group 7-12 years following the recommendations on fruit and vegetable intake or not, according to the two 
methods, is shown in the tables below. Similar results can be seen in the group of adolescents where one (out of 43) was following the recommendation on vegetable intake and four on fruit intake.

Fruit and vegetables (recommended intake $400 \mathrm{~g}$ per day or more for the age group 7-12 years).

\begin{tabular}{|c|c|c|}
\hline & $\begin{array}{l}\text { Do not follow recommenda- } \\
\text { tion according to FR }\end{array}$ & $\begin{array}{l}\text { Follow recommenda- } \\
\text { tion according to FR }\end{array}$ \\
\hline $\begin{array}{l}\text { Do not follow recommendation according to } \\
\text { NFFQ }\end{array}$ & 56 & 0 \\
\hline Follow recommendation according to NFFQ & 34 & 2 \\
\hline
\end{tabular}

Specificity $62 \%$

Sensitivity NA

Vegetables (recommended intake $200 \mathrm{~g}$ and above).

Table 17. Number of participants following recommended intake of vegetables

\begin{tabular}{lcc}
\hline & $\begin{array}{c}\text { Do not follow recommenda- } \\
\text { tion according to FR }\end{array}$ & $\begin{array}{c}\text { Follow recommenda- } \\
\text { tion according to FR }\end{array}$ \\
\hline $\begin{array}{l}\text { Do not follow recommendation according to } \\
\text { NFFQ }\end{array}$ & 91 & 0 \\
Follow recommendation according to NFFQ & 0 & 1 \\
\hline
\end{tabular}

Specificity $100 \%$

Sensitivity NA

Fruits (recommended intake $200 \mathrm{~g}$ and above).

Table 18. Number of participants following recommended intake of fruits

\begin{tabular}{lll}
\hline & $\begin{array}{l}\text { Do not follow recommen- } \\
\text { dation according to FR }\end{array}$ & $\begin{array}{l}\text { Follow recommenda- } \\
\text { tion according to FR }\end{array}$ \\
\hline $\begin{array}{lll}\text { Do not follow recommendation according to NFFQ } \\
\text { Follow recommendation according to NFFQ }\end{array}$ & 41 & 2 \\
\hline
\end{tabular}

Specificity $52 \%$

Sensitivity $85 \%$

\subsubsection{Discussion}

When comparing the frequencies obtained by the NFFQ with frequencies obtained by the FR, it must be emphasized that a complete match cannot be expected. A food frequency questionnaire record is retrospective, asking for the habitual diet as an average over the past 12 months, while the food record data are prospective based on 7 days and in other words 
the NFFQ is based on memory, while FR is not. Therefore it is likely on the individual basis that not all foods asked for in the NFFQ are eaten in this week and that results from the two methods do not fit exactly. Furthermore, frequencies calculated as servings in the food record might overestimate amounts consumed, where many small food items (e.g. pieces of candy) maybe reported in the NFFQ as eating occasions. Thus, in interpretation of the results it is more important to look at group level and the ability to rank in high and low intakes.

Also due to skewed distribution of intake and especially due to few subjects in the Icelandic adolescents group, the statistical tests show to some extent inconclusive results. But the overall results suggest that the monitoring questionnaire is suitable for both Icelandic and Danish participants.

Agreement between NFFQ and intake of macronutrients obtained by FR shows significant trends for some foods or food groups, but not for all, which is similar to the results seen in the validation study of the Swedish FFQ (Sepp et al., 2004). However the Swedish validation study saw correlations between intake of sausages or pommes frites and intake of dietary fibre, whereas the Danish study did not. This might be due to different food habits in the different countries, with a higher intake of sausages in Sweden, thus giving greater impact on e.g. dietary fibre in the Swedish diet.

It is not expected that the foods or foods groups show agreement with all macronutrients of interest, as the NFFQ do not assess the whole diet. There seems to be better agreement between NFFQ and foods or food groups than NFFQ and macronutrients, which emphasizes that the NFFQ will only indicate in which direction the dietary habits are developing, but an exact estimate of how much is eaten of a macronutrient of interest has to be calculated on basis of national dietary surveys.

The calculation of the ability of the NFFQ to detect participants following recommendations for fruit and vegetables (specificity and sensitivity) mainly shows a higher specificity than sensitivity, implying the NFFQ being better to detect participants not following recommendation than participants following the recommendations. Due to very low intake of fruit and vegetables among Icelandic participants assessing the specificity and sensitivity in Iceland has been difficult. Specificity and sensitivity calculations between the NFFQ and the food record have some uncertainty. Firstly, it is not expected that the NFFQ and the reference method (food record) show total agreement due to different methods (retrospective vs. prospective). Secondly, it is necessary to add standard portions to the data of the NFFQ for calculation the intake in 
weight on basis of frequencies and thus being able to compare intakes in weight from both methods. The introduction of standard portions will also introduce some uncertainty in the comparison.

\subsubsection{Conclusion}

The frequencies obtained by the NFFQ are positively associated to the estimated intake in grams from the food records and the NFFQ is able to rank individuals fairly acceptable. The NFFQ questionnaire is also able to detect an increasing intake of selected macronutrients by food record with increasing frequencies of some foods or food groups in the NFFQ. Especially fruits, vegetables, candy and chocolate, fish, sugar sweetened soft drinks and water are correlated to the intake of fat, saturated fat, dietary fibre and added sugar. The results indicate a good agreement between some of the foods in the NFFQ and macronutrients of interest, but the agreement is better for children and adults than for adolescents.

The questionnaires over- and underestimate the intake calculated as frequencies like other similar tools. Some of the differences in frequencies obtained by NFFQ or FR might be due to methodological differences, e.g. the concept of portion sizes versus frequency, meal habits and culinary differences. The indicator questions will capture certain aspects of dietary patterns in the Nordic countries and are intended to monitor changes/developments, but it is necessary to accept some inherent differences and to use other data sources as complimentary information.

With additional knowledge of usual portion sizes as well as eating patterns in the Nordic countries and careful interpretation of results from the diet, the indicator questionnaires can be used for comparison between countries. However it might be necessary to follow and update knowledge of portion sizes in the Nordic countries, as portion sizes develop over time.

In Denmark the ability to detect those not following recommended intake (specificity) of fruits and vegetables are higher than 70\%, whereas the ability to detect those following recommendations is somewhat lower. In Iceland, fruit and vegetable intake among children and adolescents is exceptionally low, which makes it difficult to assess specificity and sensitivity regarding the compliance to the recommendations on fruit and vegetable intake.

The project group recommends using the questionnaire for future monitoring of diet in the Nordic countries. However, when comparing between countries, national knowledge on eating patterns and portion sizes should be taken into account before interpretation. In interpreting 
the results from the NFFQ it is important to supplement with data from the national dietary surveys, as the NFFQ only indicates the level of nutrient intake.

\subsection{Validation of indicators of physical activity}

The objective of the project regarding physical activity has been to suggest and validate a common, low cost Nordic monitoring system of physical activity and sedentary behaviour. The system must be simple and possible to be integrated in current surveys.

The Nordic Physical Activity Questionnaire (NPAQ) should be able to classify the adults in five classes:

1) not meeting recommendations

2) meeting moderate-intensity recommendations

3) meeting vigorous-intensity recommendations

4) meeting the recommendation by a combination of moderate- and vigorous-intensity physical activity

5) meeting both moderate- and vigorous-intensity recommendations

Classification of adolescents and children in two classes is needed: 1) not meeting the recommendations; 2) meeting the recommendations of 60 minutes of moderate intensity PA daily.

Furthermore, the NPAQ should be able to quantify the physical activity of the respondent within each category. This would both make the monitoring surveys more sensitive to changes and trends, and would make it more flexible and adaptable to further changes or modification of the physical activity guidelines and recommendations. The Nordic recommendation for adults is to undertake a minimum of moderate physical activity for at least 30 min every day. Children and adolescents should be physical active for at least 60 min each day of both moderate and vigorous activity (Nordic Council of Ministers, 2004).

The objective of the validation study was to compare measures of the Nordic Physical Activity Questionnaire (NPAQ) used to estimate compliance with the recommendations and sedentary behaviour with measurements obtained by accelerometers. 


\subsubsection{Methods}

Pilot tests of the NPAQ were conducted in Iceland, Norway and Finland in August 2009. From the middle of October to the middle of March 2010 data were collected in all three countries, Finland, Iceland and Norway.

The NPAQ questionnaire in English was translated into each Nordic language and then translated to English by a native English speaking person, checked and compared. Afterwards the questionnaire was back translated to the Nordic languages by a native speaking person.

\section{Use of the accelerometers}

Accelerometers were handed out and participants instructed on how to wear them. Participants were not told the exact timing when they were going to be called for the telephone interview and were not supposed to fill in any diaries. Eight days later (at least 7 whole days of expected wear time) the subject was called by telephone and the PA survey was administrated by telephone interview. One to three days later, some of the participants, randomly selected, were called again and the survey was administrated again (Finland by e-mail using internet-based survey; Iceland and Norway by telephone; the analysis from this "re-test" is not included in this report). After that the accelerometer were returned and data then downloaded and checked. When the accelerometers were returned, the participants were also asked about their working/school hours, and also about swimming and bicycling during the monitoring period. Activity during the reported working and school hours were deleted from each participants recording. Only data from participants who had at least 5 days of valid accelerometer data were included in the analysis.

ActiGraph accelerometers, models GT1M and GT3X, were used. Only the vertical axis from GT3X was used as it is comparable with the GT1M data. Epoch periods of 5-15 s were used and data were summed to 1 min epochs before further analysis. All accelerometer data files were processed by an algorithm that was created in MATLAB programming language. Established or common criteria from the literature were used for the data processing (Troiano et al.., 2008). They were as follows:

For adults: Non-wear time was defined as $\geq 60 \mathrm{~min}$ of no activity recordings. A valid day was defined as at least 10 hours of activity recordings. A bout was defined as activity above a given threshold that did not contain more than two separate or consecutive minutes of activity below respective threshold within each $10 \mathrm{~min}$ bout. Threshold for moderate 
activity was defined as 2,020 cpm and for vigorous activity as 5,999 cpm. Thresholds were defined for sedentary activity as at least 10 min of continuous activity below $100 \mathrm{cpm} .^{3}$

For adolescents and children: Non-wear time was defined as 30 min of no activity or longer. To count as a valid day, at least 10 hours of activity should be recorded. A bout was defined as activity above a given threshold that did not contain more than two separate or consecutive minutes of activity below respective threshold within each 10 min segment. Threshold for moderate activity was defined as $2,000 \mathrm{cpm}$. Thresholds were defined for sedentary activity as at least $10 \mathrm{~min}$ of continuous activity below $100 \mathrm{cpm}$.

\section{Participants}

Three age groups, referred to as adults (18-65 years old), adolescents (13-17 y) and children (7-12 y) participated in the validation study. Separate questionnaires were used for each age group. Adults and adolescents answered the surveys for themselves whereas one of the parents (usually the mother) answered for the children. The aim was to collect data for at least 50 participants in each age group in each of the three countries involved in the validation study, i.e. total of at least 150 in each country and 450 participants total in the three countries. The aim was accomplished (table 19). However, not all of the participants provided enough accelerometer data to be used in the analyses. The participants for the validation study were recruited through advertisements in schools and workplaces in Finland, Iceland and Norway and all ages, gender and educational level was represented in the study. The sample was heterogeneous in each country (gender, age, education, community, importance in this order). Participants who volunteered to participate in the study received study information and signed informed consent.

For comparison between data from questionnaires and accelerometer paired t-test was applied. Correlations between methods were shown using Pearson correlation coefficients.

3 Counts per minute. 
Table 19. Number of participants with both questionnaires and accelerometer data.

\begin{tabular}{lrrrrrrrrrr}
\hline & \multicolumn{3}{c}{ Adults } & \multicolumn{3}{c}{ Adolescents } & \multicolumn{3}{c}{ Children } \\
& males & females & all & males & females & All & males & females & all \\
\hline Finland & 24 & 31 & 55 & 26 & 41 & 67 & 40 & 34 & 74 \\
Iceland & 26 & 38 & 64 & 23 & 34 & 57 & 30 & 37 & 67 \\
Norway & 25 & 43 & 68 & 30 & 14 & 44 & 33 & 44 & 77 \\
All & 75 & 112 & 187 & 79 & 89 & 168 & 103 & 115 & 218 \\
\hline
\end{tabular}

\subsubsection{Results}

Adults

Adults were asked for both moderate-to-vigorous physical activity (MVPA) and vigorous physical activity (VPA), both number of days that reach the recommended level and also total time in a week (tables 20-23). Moderate correlations ( $\mathrm{r}=0.30$ to 0.51 ) were found between the selfreported values and the accelerometers values for MVPA, both for number of days (table 21) and total time (table 20). Except for the Icelandic data, the correlations were similar for the VPA ( $\mathrm{r}=0.36$ to 0.60$)$. However, the self-reported values were always significantly higher than the accelerometer data or 2-9 times higher on average (tables 20-23). In Finland, 16\% of the participants in the validation study reported cycling during the study for on average 0.4 hours/week and 23\% reported swimming for 1.0 hours/week. If it is assumed that all of this activity was MVPA and none of the bicycling activity was registered by the accelerometers above the MVP cut-point, the objective measures MVPA average for Finland would increase from 2.1 hours/week to 2.4 hours/week (table 21). The difference between self-reported and objectively registered data would decrease from 2.3 to 2.0 hours/week. Similar numbers are expected for the Norwegian data and the numbers for the Icelandic data are lower.

\begin{tabular}{|c|c|c|c|c|c|c|c|c|c|}
\hline \multirow[t]{2}{*}{$\begin{array}{l}\text { Q2a } \\
\text { (5 valid days) }\end{array}$} & & \multirow[b]{2}{*}{$\mathbf{n}$} & \multicolumn{2}{|c|}{ Questionnaires } & \multicolumn{2}{|c|}{ Accelerometers } & \multirow{2}{*}{$\begin{array}{l}\text { Paired } \\
\text { t-test } \\
\text { p-value }\end{array}$} & \multicolumn{2}{|c|}{$\begin{array}{l}\text { Correlation } \\
\text { coefficient }\end{array}$} \\
\hline & & & Mean & SD & Mean & SD & & Pearson & $p$-value \\
\hline \multirow{4}{*}{$\begin{array}{l}\text { Number of days of } \\
30 \text { min of MVPA } \\
\text { reached in mini- } \\
\text { mum } 10 \text { min bouts } \\
\text { [d/week] }\end{array}$} & Finland & 47 & 3.4 & 2.4 & 1.7 & 2.1 & $<0.001$ & 0.51 & $<0.001$ \\
\hline & Iceland & 59 & 3,4 & 2,2 & 0,9 & 1,5 & $<0,001$ & 0,47 & $<0,001$ \\
\hline & Norway & 59 & 4,1 & 2,2 & 1,7 & 1,7 & $<0,001$ & 0,46 & $<0,001$ \\
\hline & All & 165 & 3,6 & 2,3 & 1,4 & 1,8 & $<0,001$ & 0,48 & $<0,001$ \\
\hline
\end{tabular}


Table 21. MVPA total time in adults. Total time weekly of moderate-to-vigorous physical activity in hours per week. P-values for comparison of questionnaires and accelerometers means by paired t-test and $p$-values for correlation coefficients are shown

\begin{tabular}{|c|c|c|c|c|c|c|c|c|c|}
\hline \multirow[t]{2}{*}{$\begin{array}{l}\text { Q2b } \\
\text { (5 valid days) }\end{array}$} & & \multirow[b]{2}{*}{$n$} & \multicolumn{2}{|c|}{ Questionnaires } & \multicolumn{2}{|c|}{ Accelerometers } & \multirow{2}{*}{$\begin{array}{c}\text { Paired } \\
\text { t-test } \\
\text { p-value }\end{array}$} & \multicolumn{2}{|c|}{$\begin{array}{c}\text { Correlation coeffi- } \\
\text { cient }\end{array}$} \\
\hline & & & Mean & SD & Mean & SD & & Pearson & p-value \\
\hline Total time in & Finland & 47 & 4.4 & 4.8 & 2.1 & 2.3 & 0.001 & 0.30 & 0.04 \\
\hline MVPA that & Iceland & 59 & 4.6 & 4.7 & 1.1 & 1.4 & $<0.001$ & 0.31 & 0.02 \\
\hline lasted at least & Norway & 59 & 5.1 & 3.4 & 2.1 & 1.8 & $<0.001$ & 0.45 & $<0.001$ \\
\hline $\begin{array}{l}10 \text { min each } \\
\text { time [hrs/week] }\end{array}$ & All & 165 & 4.7 & 4.3 & 1.7 & 1.9 & $<0.001$ & 0.33 & $<0.001$ \\
\hline
\end{tabular}

Table 22. VPA days in adults. Number of days reaching $\mathbf{2 0}$ min of continuous vigorous physical activity. P-values for comparison of questionnaires and accelerometers means by paired t-test and $p$-values for correlation coefficients are shown

\begin{tabular}{|c|c|c|c|c|c|c|c|c|c|}
\hline \multirow[t]{2}{*}{$\begin{array}{l}\text { Q3a } \\
\text { (5 valid days) }\end{array}$} & & \multirow[b]{2}{*}{$\mathrm{n}$} & \multicolumn{2}{|c|}{ Questionnaires } & \multicolumn{2}{|c|}{ Accelerometers } & \multirow{2}{*}{$\begin{array}{l}\text { Paired } \\
\text { t-test } \\
\text { p-value }\end{array}$} & \multicolumn{2}{|c|}{$\begin{array}{c}\text { Correlation } \\
\text { coefficient }\end{array}$} \\
\hline & & & Mean & SD & Mean & SD & & Pearson & p-value \\
\hline Number of days & Finland & 47 & 0.7 & 1.3 & 0.3 & 1.1 & 0.008 & 0.60 & $<0.001$ \\
\hline of $20 \mathrm{~min}$ of & Iceland & 59 & 1.4 & 1.9 & 0.3 & 0.7 & $<0.001$ & 0.06 & 0.63 \\
\hline VPA reached in & Norway & 59 & 1.7 & 1.8 & 0.4 & 1.0 & $<0.001$ & 0.53 & $<0.001$ \\
\hline $\begin{array}{l}\text { minimum } 20 \\
\text { min bouts } \\
\text { [d/week] }\end{array}$ & All & 165 & 1.3 & 1.8 & 0.3 & 0.9 & $<0.001$ & 0.38 & $<0.001$ \\
\hline
\end{tabular}

Table 23. VPA total time in adults. Total time weekly of vigorous physical activity. P-values for comparison of questionnaires and accelerometers means by paired t-test and $\mathrm{p}$-values for correlation coefficients are shown

\begin{tabular}{|c|c|c|c|c|c|c|c|c|c|}
\hline \multirow[t]{2}{*}{$\begin{array}{l}\text { Q3b } \\
\text { (5 valid days) }\end{array}$} & & \multirow[b]{2}{*}{$\mathrm{n}$} & \multicolumn{2}{|c|}{ Questionnaires } & \multicolumn{2}{|c|}{ Accelerometers } & \multirow{2}{*}{$\begin{array}{l}\text { Paired } \\
\text { t-test } \\
\text { p-value }\end{array}$} & \multicolumn{2}{|c|}{$\begin{array}{l}\text { Correlation } \\
\text { coefficient }\end{array}$} \\
\hline & & & Mean & SD & Mean & SD & & $\begin{array}{l}\text { Pear- } \\
\text { son }\end{array}$ & p-value \\
\hline Total time in & Finland & 47 & 0.8 & 1.8 & 0.2 & 0.8 & 0.008 & 0.46 & 0.001 \\
\hline VPA that last- & Iceland & 59 & 1.9 & 3.6 & 0.2 & 0.5 & 0.001 & 0.05 & 0.68 \\
\hline ed at least 10 & Norway & 58 & 1.7 & 1.9 & 0.4 & 0.9 & $<0.001$ & 0.36 & 0.006 \\
\hline min each time & All & 164 & 1.5 & 2.6 & 0.3 & 0.7 & $<0.001$ & 0.23 & 0.003 \\
\hline
\end{tabular}

The American College of Sports Medicine/American Heart Association (ACSM/AHA) recommendations recognize that the recommended minimum of physical activity can also be reached by 3 days of vigorous physical activity that last at least 20 min each time (Haskel et al.., 2007a,b). The recommendations can also be reached by combining moderate and vigorous activity. In our analyses we adopted this to the Nordic recommendations and defined PA categories accordingly (Table 24). Although, the Nordic recommendations state minimum amount (30 min for adults) of physical activity per day, it is also recognized that recommended physical activity can be reached by accumulating enough physical activity over a week. Therefore, the questionnaires (version A) were devel- 
oped to include both modes of recommendations: a) number of days per week that activity reached recommended level; and b) hours of accumulated activity per week. The reason for including both modes in the validation study was to enable comparison of the validity of both types of questions. Also, this was done to keep the option open to include both in the final monitoring system or to choose, pending on the validation results, one of the modes. ${ }^{4}$ Following analysis is thus conducted separately for both modes. The main purpose of the questionnaires is to monitor the proportion of people meeting the PA recommendations according to the PA categories (table 24). The current questionnaires are able to identify these categories and the accelerometers were analysed according to the same protocol. As expected, a higher part of the participants reached the recommendations according to the self-reported questions than according to the accelerometer data (table 25).

Table 24. Definition of Physical activity categories (PAC) according to the Nordic recommendations for adults. A: PAC according to days reaching recommended level of PA per day (modality a); B. PAC according to hours per week of recommended PA (modality b); C: Description of definition of PACs.

\section{A. PAC according to Nordic recommendation of days per week}

\begin{tabular}{|c|c|c|c|c|c|c|c|c|}
\hline \multirow[b]{2}{*}{ Number of days/week with VPA } & \multicolumn{8}{|c|}{ Number of days/week with MPA [(MVPA day/week) - (VPA day/week)] } \\
\hline & 0 & 1 & 2 & 3 & 4 & 5 & 6 & 7 \\
\hline 0 & 0 & 1 & 1 & 1 & 1 & 1 & 1 & 2 \\
\hline 1 & 1 & 1 & 1 & 1 & 1 & 4 & 4 & \\
\hline 2 & 1 & 1 & 1 & 4 & 4 & 4 & & \\
\hline 3 & 3 & 3 & 3 & 3 & 3 & & & \\
\hline 4 & 3 & 3 & 3 & 3 & & & & \\
\hline 5 & 3 & 3 & 3 & & & & & \\
\hline 6 & 3 & 3 & & & & & & \\
\hline 7 & 3 & & & & & & & \\
\hline
\end{tabular}

B. PAC according to Nordic recommendation of hours per week

Numbers of hours/week with MPA [(MVPA hour/week) (VPA hour/week)]

\begin{tabular}{lllllllll} 
Number of hours/week with VPA & $\mathbf{0}$ & $\mathbf{0 . 5}$ & $\mathbf{1}$ & $\mathbf{1 . 5}$ & $\mathbf{2}$ & $\mathbf{2 . 5}$ & $\mathbf{3}$ & $>=\mathbf{3 . 5}$ \\
\hline 0 & 0 & 1 & 1 & 1 & 1 & 1 & 1 & 2 \\
0,5 & 1 & 1 & 1 & 1 & 1 & 4 & 4 & 2 \\
1 & 1 & 1 & 4 & 4 & 4 & 4 & 4 & 2 \\
$>=1,5$ & 3 & 3 & 3 & 3 & 3 & 3 & 3 & 5 \\
\hline
\end{tabular}

${ }^{4}$ As described later, it has been decided to recommend that a questionnaire including mode b (called Questionnaire version $B$ ) is sufficient to use for the future monitoring, but in this report results from both modes are shown 


\section{Physical activity categories and definition}

PAC Definition

Not meeting recommendations on any day, or less than $15 \mathrm{~min} /$ week

$1 \quad$ Not meeting weekly recommendations, but reaching at least one day of recommended activity or 15 $\mathrm{min} /$ week

2 Meeting moderate-intensity recommendations ( 7 days of at least $30 \mathrm{~min}$ each day or 3.5 hours per week; both in minimum bouts of $10 \mathrm{~min}$ )

3 Meeting vigorous-intensity recommendations (3 days of at least 20 min continuous activity each day, or 1.25 hours per week in minimum of 10 min bouts)

4 Meeting the recommendation by a combination of moderate- and vigorous-intensity physical activity

$5 \quad$ Meeting both moderate- and vigorous-intensity recommendations (only applicable to hours per week recommendations) 
Table 25. Number and proportion (\%) reaching each of the six PA categories (PAC) according to the Nordic recommendations (see table 24) by the questionnaires (Ques) and accelerometers (Acc) in adults

A. Nordic recommendation of days per week

\begin{tabular}{|c|c|c|c|c|c|c|c|c|c|c|c|c|c|c|c|c|}
\hline \multirow[b]{2}{*}{ PAC } & \multicolumn{2}{|c|}{ All } & \multicolumn{2}{|c|}{ Finland } & \multicolumn{2}{|c|}{ Iceland } & \multicolumn{2}{|c|}{ Norway } & \multicolumn{2}{|c|}{ All } & \multicolumn{2}{|c|}{ Finland } & \multicolumn{2}{|c|}{ Iceland } & \multicolumn{2}{|c|}{ Norway } \\
\hline & Ques & Acc & Ques & Acc & Ques & Acc & Ques & Acc & Ques & Acc & Ques & $A c c$ & Ques & Acc & Ques & Acc \\
\hline \multirow[t]{2}{*}{0} & 19 & 75 & 8 & 20 & 7 & 34 & 4 & 21 & 17 & 37 & 7 & 13 & 7 & 19 & 3 & 5 \\
\hline & $12 \%$ & $45 \%$ & $17 \%$ & $43 \%$ & $12 \%$ & $58 \%$ & $7 \%$ & $36 \%$ & $10 \%$ & $22 \%$ & $15 \%$ & $28 \%$ & $12 \%$ & $32 \%$ & $5 \%$ & $8 \%$ \\
\hline \multirow[t]{2}{*}{1} & 88 & 78 & 25 & 22 & 33 & 22 & 30 & 34 & 45 & 94 & 15 & 23 & 17 & 32 & 13 & 39 \\
\hline & $53 \%$ & $47 \%$ & $53 \%$ & $47 \%$ & $56 \%$ & $37 \%$ & $51 \%$ & $58 \%$ & $27 \%$ & $57 \%$ & $32 \%$ & $49 \%$ & $29 \%$ & $54 \%$ & $22 \%$ & $66 \%$ \\
\hline \multirow[t]{2}{*}{2} & 11 & 2 & 6 & 2 & 2 & 0 & 3 & 0 & 43 & 17 & 14 & 8 & 12 & 2 & 17 & 7 \\
\hline & $7 \%$ & $1 \%$ & $13 \%$ & $4 \%$ & $3 \%$ & $0 \%$ & $5 \%$ & $0 \%$ & $26 \%$ & $10 \%$ & $30 \%$ & $17 \%$ & $20 \%$ & $3 \%$ & $29 \%$ & $12 \%$ \\
\hline \multirow[t]{2}{*}{3} & 41 & 5 & 5 & 2 & 17 & 1 & 19 & 2 & 38 & 12 & 7 & 2 & 17 & 4 & 14 & 6 \\
\hline & $25 \%$ & $3 \%$ & $11 \%$ & $4 \%$ & $29 \%$ & $2 \%$ & $32 \%$ & $3 \%$ & $23 \%$ & $7 \%$ & $15 \%$ & $4 \%$ & $29 \%$ & $7 \%$ & $24 \%$ & $10 \%$ \\
\hline \multirow[t]{2}{*}{4} & 6 & 5 & 3 & 1 & 0 & 2 & 3 & 2 & 5 & 3 & 1 & 1 & 3 & 1 & 1 & 1 \\
\hline & $4 \%$ & $3 \%$ & $6 \%$ & $2 \%$ & $0 \%$ & $3 \%$ & $5 \%$ & $3 \%$ & $3 \%$ & $2 \%$ & $2 \%$ & $2 \%$ & $5 \%$ & $2 \%$ & $2 \%$ & $2 \%$ \\
\hline \multirow[t]{2}{*}{5} & & & & & & & & & 17 & 2 & 3 & 0 & 3 & 1 & 11 & 1 \\
\hline & & & & & & & & & $10 \%$ & $1 \%$ & $6 \%$ & $0 \%$ & $5 \%$ & $2 \%$ & $19 \%$ & $2 \%$ \\
\hline \multirow[t]{2}{*}{ all } & 165 & 165 & 47 & 47 & 59 & 59 & 59 & 59 & 165 & 165 & 47 & 47 & 59 & 59 & 59 & 59 \\
\hline & $100 \%$ & $100 \%$ & $100 \%$ & $100 \%$ & $100 \%$ & $100 \%$ & $100 \%$ & $100 \%$ & $100 \%$ & $100 \%$ & $100 \%$ & $100 \%$ & $100 \%$ & $100 \%$ & $100 \%$ & $100 \%$ \\
\hline Specificity* & $67 \%$ & & $74 \%$ & & $68 \%$ & & $62 \%$ & & $47 \%$ & & $61 \%$ & & $47 \%$ & & $36 \%$ & \\
\hline Sensitivity** & $67 \%$ & & $60 \%$ & & $33 \%$ & & $100 \%$ & & $100 \%$ & & $100 \%$ & & $100 \%$ & & $100 \%$ & \\
\hline Not meeting recommendations & $65 \%$ & $93 \%$ & $70 \%$ & $89 \%$ & $68 \%$ & $95 \%$ & $58 \%$ & $93 \%$ & $38 \%$ & $79 \%$ & $47 \%$ & $77 \%$ & $41 \%$ & $86 \%$ & $27 \%$ & $75 \%$ \\
\hline Meeting recommendations & $35 \%$ & $7 \%$ & $30 \%$ & $11 \%$ & $32 \%$ & $5 \%$ & $42 \%$ & $7 \%$ & $62 \%$ & $21 \%$ & $53 \%$ & $23 \%$ & $59 \%$ & $14 \%$ & $73 \%$ & $25 \%$ \\
\hline
\end{tabular}

*Specificity is defined as the number of subjects not meeting the Nordic frequency recommendation by both questionnaires and accelerometers as a percentage of those actually not meeting the recommendations according to the accelerometers.

**Sensitivity is defined as the number of subjects meeting the Nordic frequency recommendation by both questionnaires and acc elerometers as a percentage of those actually meeting the recommendations according to the accelerometers. 
The questionnaires included questions about TV and computer time. The hypothesis was that the responses would reflect sedentary behaviour. Except for responses in Iceland there was moderate correlation between reported TV and computer time and sedentary time measured by accelerometers ( $\mathrm{r}=0.29-0.46)$ (Table 26). However, the accelerometers indicated that participants performed significantly more time doing sedentary pursuits than the TV and computer questions showed. Still information on screen time could be interesting in its own right as some research indicate that screen time has more severe health consequences than other sedentary behaviour (Stamatakis et al.., 2011).

Table 26. Sedentary time in adults. Total time daily of sedentary time in hours per day. Sedentary activity ( $<100 \mathrm{cpm}$ for at least $10 \mathrm{~min}$ at a time). P-values for comparison of questionnaires and accelerometers means by paired t-test and p-values for correlation coefficients are shown

\begin{tabular}{|c|c|c|c|c|c|c|c|c|c|}
\hline \multirow[t]{2}{*}{$\begin{array}{l}\text { Q4(a+b) } \\
\text { (5 valid days) }\end{array}$} & & \multirow[b]{2}{*}{ n } & \multicolumn{2}{|c|}{ Questionnaires } & \multicolumn{2}{|c|}{ Accelerometers } & \multirow{2}{*}{$\begin{array}{l}\text { Paired } \\
\text { t-test } \\
\text { p-value }\end{array}$} & \multicolumn{2}{|c|}{$\begin{array}{l}\text { Correlation } \\
\text { coeeficient }\end{array}$} \\
\hline & & & Mean & SD & Mean & SD & & Pearson & p-value \\
\hline Sedentary time & Finland & 47 & 2.2 & 1.1 & 4.3 & 1.4 & $<0.001$ & 0.46 & 0.001 \\
\hline (<100 cpm) & Iceland & 59 & 2.6 & 1.6 & 4.7 & 2.6 & $<0.001$ & 0.07 & 0.61 \\
\hline compared to TV & Norway & 59 & 2.8 & 1.6 & 4.5 & 1.8 & $<0.001$ & 0.29 & 0.03 \\
\hline $\begin{array}{l}\text { and computer } \\
\text { time [hours/day] }\end{array}$ & All & 165 & 2.5 & 1.5 & 4.5 & 2.0 & $<0.001$ & 0.20 & 0.009 \\
\hline
\end{tabular}

The last question in the questionnaires asked about the general leisuretime activity level of the respondent (Saltin and Grimby, 1968). This question is not able to identify in the same way as the other questions if recommendations are reached or not. However, there is moderate correlation between the response to this question and all the accelerometer variables that were used above and also total accelerometers counts, except for the sedentary variable (Table 27 ). 
Table 27. Correlations of leisure-time activity level (Question 5) with selected accelerometer variables in adults

\begin{tabular}{lccc}
\hline Accelerometer variable & $\begin{array}{c}\text { Pearson correla- } \\
\text { tion coefficient }\end{array}$ & p-value & $\mathbf{n}$ \\
\hline Total counts [cpm] & 0.44 & $<0.001$ & 164 \\
Number of days 30 min of moderate activity reached in mini- & 0.38 & $<0.001$ & 164 \\
mum 10 min bouts & & 164 \\
$\begin{array}{l}\text { Total time in moderate activity that lasted at least 10 min each } \\
\text { time [hours/week] }\end{array}$ & 0.37 & $<0.001$ & 164 \\
$\begin{array}{l}\text { Number of days } 20 \text { min of vigorous activity reached in minimum } \\
20 \text { min bouts }\end{array}$ & 0.29 & $<0.001$ & 164 \\
$\begin{array}{l}\text { Total time in vigorous activity that lasted at least 10 min each } \\
\text { time [hours/week] }\end{array}$ & 0.30 & $<0.001$ & 164 \\
$\begin{array}{l}\text { Sedentary time }(<100 \text { cpm) compared to TV and computer time } \\
\text { [hours/day] }\end{array}$ & 0.01 & 0.90 \\
\hline
\end{tabular}

\section{Adolescents}

Adolescents were asked for both number of days and total time spent in MVPA over the last seven days. To keep conformity with the adult and children questionnaires, it was decided to exclude activity at school and work from the questions. Moderate correlations ( $r=0.36$ to 0.62 ) were found between the self-reported answers and accelerometer data (Tables 28 and 29). However, except for the Norwegian MVPA days and MVPA total time data, the questionnaires indicated much higher activity than the accelerometer data. In Finland, $44 \%$ of the adolescents in the validation study reported cycling during the study for on average 2.4 hours/week and 4\% reported swimming for 2.5 hours/week. If it is assumed that all of this activity was MPA and none of the bicycling activity was registered by the accelerometers above the MVP cut-point, the objective measures MVPA average for Finland would increase from 4.5 hours/week to 5.7 hours/week. The difference between self-reported and objectively registered data would thus disappear. Similar amount of bicycling/swimming PA is expected for the Norwegian adolescents but less for the Icelandic adolescents.

As for adults, the data was analysed for both modes of reaching recommendations of physical activity: a) reaching recommended level of PA on each day of the week; and b) reaching recommended amount of accumulated PA in a week. Physical activity categories for adolescents were defined as: reaching recommendation on no day or less than 15 min/week (PAC 0); not meeting the recommendations but reaching more activity than for PAC 0 (PAC 1); or meeting the recommendations ( $\geq 60 \mathrm{~min}$ of moderate-to-vigorous PA per day 7 days/week or 7 
hours/week). The proportions in each category according to questionnaires and accelerometers respectively are shown in table 30. No correlation was found between reported TV and computer time and sedentary time according to the accelerometer data (Table 31). Also, the accelerometers indicated more time spent sedentary than TV and computer time indicated by the self-reported questions.

Table 28. MVPA days in adolescents. Number of days per week reaching $\geq 60 \mathrm{~min}$ of moderate-tovigorous physical activity. P-values for comparison of questionnaires and accelerometers means by paired $t$-test and $p$-values for correlation coefficients are shown

\begin{tabular}{|c|c|c|c|c|c|c|c|c|c|}
\hline \multirow[t]{2}{*}{ Q1a (2000 cpm) } & & \multirow[b]{2}{*}{$\mathrm{n}$} & \multicolumn{2}{|c|}{ Questionnaires } & \multicolumn{2}{|c|}{$\begin{array}{l}\text { Accelerome- } \\
\text { ters }\end{array}$} & \multirow{2}{*}{$\begin{array}{l}\begin{array}{c}\text { Paired } \\
\text { t-test }\end{array} \\
\text { p-value }\end{array}$} & \multicolumn{2}{|c|}{$\begin{array}{l}\text { Correlation } \\
\text { coefficient }\end{array}$} \\
\hline & & & Mean & SD & Mean & SD & & $\begin{array}{l}\text { Pear- } \\
\text { son }\end{array}$ & $\begin{array}{l}p- \\
\text { value }\end{array}$ \\
\hline Number of days & Finland & 40 & 3.3 & 1.5 & 1.4 & 1.5 & $<0.001$ & 0.36 & 0.02 \\
\hline $60 \mathrm{~min}$ of MVPA & Iceland & 35 & 4.9 & 1.7 & 2.3 & 2.3 & $<0.001$ & 0.53 & 0.001 \\
\hline (> 2000 & Norway & 27 & 3.5 & 2.0 & 3.1 & 1.9 & 0.38 & 0.52 & 0.006 \\
\hline cpm)[d/week] & All & 102 & 3.9 & 1.9 & 2.2 & 2.0 & $<0.001$ & 0.44 & $<0.001$ \\
\hline
\end{tabular}

Table 29. MVPA total time in adolescents. Total time weekly of moderate-to-vigorous physical activity in hours per week. P-values for comparison of questionnaires and accelerometers means by paired t-test and p-values for correlation coefficients (c.c.) are shown

\begin{tabular}{|c|c|c|c|c|c|c|c|c|c|}
\hline \multirow[t]{2}{*}{$\begin{array}{l}\text { Q1b (2000 } \\
\text { cpm) }\end{array}$} & & \multirow[b]{2}{*}{ n } & \multicolumn{2}{|c|}{ Questionnaires } & \multicolumn{2}{|c|}{$\begin{array}{l}\text { Accelerome- } \\
\text { ters }\end{array}$} & \multirow{2}{*}{$\begin{array}{l}\text { Paired } \\
\text { t-test } \\
\text { p-value }\end{array}$} & \multicolumn{2}{|c|}{$\begin{array}{l}\text { Correlation } \\
\text { coefficient }\end{array}$} \\
\hline & & & Mean & SD & Mean & SD & & $\begin{array}{r}\text { Pear- } \\
\text { son }\end{array}$ & $\begin{array}{l}p- \\
\text { value }\end{array}$ \\
\hline Total time in & Finland & 40 & 5.5 & 3.7 & 4.5 & 1.9 & 0.07 & 0.36 & 0.02 \\
\hline MVPA (>2000 & Iceland & 35 & 8.0 & 3.8 & 5.8 & 3.2 & 0.001 & 0.48 & 0.003 \\
\hline cpm) & Norway & 27 & 5.8 & 3.5 & 7.1 & 3.2 & 0.03 & 0.62 & 0.001 \\
\hline [hours/week] & All & 102 & 6.4 & 3.8 & 5.6 & 2.9 & 0.02 & 0.45 & $<0.001$ \\
\hline
\end{tabular}


Table 30. Number and portion (\%) reaching each of the three PA categories according to the Nordic recommendations (see Table 24) by the questionnaires (Ques) and accelerometers (Acc) in adolescents. See Table 25 for definition of specificity and sensitivity

\begin{tabular}{|c|c|c|c|c|c|c|c|}
\hline \multicolumn{8}{|c|}{ B. Nordic recommendation of hours per week } \\
\hline \multicolumn{2}{|c|}{ All countries } & \multicolumn{2}{|c|}{ Finland } & \multicolumn{2}{|c|}{ Iceland } & \multicolumn{2}{|c|}{ Norway } \\
\hline Ques & Acc & Ques & Acc & Ques & Acc & Ques & Acc \\
\hline 2 & 0 & 0 & 0 & 1 & 0 & 1 & 0 \\
\hline $2 \%$ & $0 \%$ & $0 \%$ & $0 \%$ & $3 \%$ & $0 \%$ & $4 \%$ & $0 \%$ \\
\hline 60 & 74 & 29 & 34 & 14 & 26 & 17 & 14 \\
\hline $59 \%$ & $73 \%$ & $73 \%$ & $85 \%$ & $40 \%$ & $74 \%$ & $63 \%$ & $52 \%$ \\
\hline 40 & 28 & 11 & 6 & 20 & 9 & 9 & 13 \\
\hline $39 \%$ & $27 \%$ & $28 \%$ & $15 \%$ & $57 \%$ & $26 \%$ & $33 \%$ & $48 \%$ \\
\hline 102 & 102 & 40 & 40 & 35 & 35 & 27 & 27 \\
\hline $100 \%$ & $100 \%$ & $100 \%$ & $100 \%$ & $100 \%$ & $100 \%$ & $100 \%$ & $100 \%$ \\
\hline $72 \%$ & & $76 \%$ & & $58 \%$ & & $86 \%$ & \\
\hline $68 \%$ & & $50 \%$ & & $100 \%$ & & $54 \%$ & \\
\hline $61 \%$ & $73 \%$ & $73 \%$ & $85 \%$ & $43 \%$ & $74 \%$ & $67 \%$ & $52 \%$ \\
\hline $39 \%$ & $27 \%$ & $28 \%$ & $15 \%$ & $57 \%$ & $26 \%$ & $33 \%$ & $48 \%$ \\
\hline
\end{tabular}

${ }^{5}$ No one meets the recommendation according to the accelerometers, thus the result of calculation of sensitivity will show the value infinity. 
Table 31. Sedentary activity in adolescents. Sedentary activity $(<100 \mathrm{cpm}$ for at least $10 \mathrm{~min}$ at a time). P-values for comparison of questionnaires and accelerometers means by paired t-test and p-values for correlation coefficients are shown

\begin{tabular}{|c|c|c|c|c|c|c|c|c|c|}
\hline \multirow[t]{2}{*}{$\begin{array}{l}\mathrm{Q} 2(\mathrm{a}+\mathrm{b})(<100 \\
\mathrm{cpm})\end{array}$} & & \multirow[b]{2}{*}{$\mathrm{n}$} & \multicolumn{2}{|c|}{ Questionnaires } & \multicolumn{2}{|c|}{$\begin{array}{r}\text { Accelerome- } \\
\text { ters }\end{array}$} & \multirow{2}{*}{$\begin{array}{r}\text { Paired } \\
\text { t-test } \\
p- \\
\text { value }\end{array}$} & \multicolumn{2}{|c|}{$\begin{array}{c}\text { Correlation } \\
\text { coefficient }\end{array}$} \\
\hline & & & Mean & SD & Mean & SD & & $\begin{array}{r}\text { Pear- } \\
\text { son }\end{array}$ & $\begin{array}{r}p- \\
\text { value }\end{array}$ \\
\hline \multirow{4}{*}{$\begin{array}{l}\text { Sedentary time } \\
(<100 \mathrm{cpm}) \\
\text { compared to TV } \\
\text { and computer } \\
\text { time } \\
\text { [hours/day] }\end{array}$} & Finland & 40 & 2.4 & 1.2 & 3.7 & 1.0 & $<0.001$ & 0.23 & 0.15 \\
\hline & Iceland & 35 & 2.9 & 1.5 & 4.1 & 2.5 & 0.02 & 0.15 & 0.40 \\
\hline & Norway & 27 & 2.9 & 1.2 & 3.8 & 1.2 & 0.008 & 0.08 & 0.69 \\
\hline & All & 102 & 2.7 & 1.3 & 3.9 & 1.7 & $<0.001$ & 0.16 & 0.11 \\
\hline
\end{tabular}

The last question in the questionnaires asked about the general leisuretime activity level of the respondent. As for adults, this question is not able to identify in the same way as the other questions if recommendations are reached or not. However, it shows moderate correlation with all the accelerometer variables that were used above and also with total accelerometers counts, except for the sedentary variable (table 32).

Table 32. Correlations of general leisure-time activity level (Question 3), ${ }^{6}$ with selected accelelometer variables in adolescents

\begin{tabular}{lrrr}
\hline Accelerometer variable & $\begin{array}{r}\text { Pearson } \\
\text { correlation } \\
\text { coefficient }\end{array}$ & p-value & $\mathbf{n}$ \\
\hline Total counts [cpm] & 0.52 & $<0.001$ & 102 \\
Number of days 60 min of activity, moderate or more $(>2000 \mathrm{cpm})$ & 0.52 & $<0.001$ & 102 \\
Total time in moderate activity $(>2000 \mathrm{cpm})$ [hours/week] & 0.52 & $<0.001$ & 102 \\
Sedentary time $(<100 \mathrm{cpm})$ compared to TV and computer time & -0.11 & 0.28 & 102 \\
[hours/day] & & &
\end{tabular}

\section{Children}

One of the parents was asked about their children's physical activity with an identical questionnaire as for the adolescents. As it is difficult for the parents to know how physically active their child is at school, it was

${ }^{6}$ (Question 3 (classification of leisure-time physical activity)) Interviewer: Choose one of the following descriptions that best fits your leisure time activity during the last 7 days. (1) Reading, watching TV or other sedentary activity. (2) Walking, cycling, or other forms of light exercise that lasted for at least 4 hours during the last 7 days. Include walking or cycling to and from school or work, active recreation, etc. (such as skate boarding or rollerblading). (3) Participation in recreational sports, etc. (such as football or swimming), where the duration of activity lasted for at least 4 hours in total during the last 7 days. (4) Participation in hard training or sports competitions, regularly several times during the last 7 days. 
decided to exclude activity at school from the questions. Except for the Finnish data, there was a moderate correlation between the parent's responses and the accelerometer data (tables 33 and 34). As for the adolescents, the questionnaire indicated significantly higher physical activity level than the accelerometers (except for Iceland for total time). In Finland, $43 \%$ of the adolescents in the validation study reported cycling during the study for on average 2.1 hours/week and 17\% reported swimming for 1.8 hours/week. If it is assumed that all of this activity was MPA and none of the bicycling activity was registered by the accelerometers above the MVP cut-point, the objective measures MVPA average for Finland would increase from 5.9 hours/week to 7.1 hours/week. The difference between self-reported and objectively registered data would thus decrease from 2.8 hours/week to 1.6 hours/week. Similar amount of bicycling/swimming PA is expected for the Norwegian children but less for the Icelandic children

The data were analysed in the same way as for adolescents and physical activity categories were also defined as for the adolescents. Proportions in each category according to questionnaires and accelerometers respectively are shown in Table 35 . Only Norway showed significant correlation between TV and computer time and sedentary time according to the accelerometer data. Significantly more sedentary time was indicated by the accelerometers than the questionnaires (table 36).

Table 33. MVPA days in children. Number of days reaching $60 \mathrm{~min}$ of moderate-to-vigorous physical activity. P-values for comparison of questionnaires and accelerometers means by paired t-test and $p$-values for correlation coefficients are shown

\begin{tabular}{|c|c|c|c|c|c|c|c|c|c|}
\hline \multirow[t]{2}{*}{$\begin{array}{l}\text { Q1a } \\
(2000 \mathrm{cpm})\end{array}$} & & \multirow[b]{2}{*}{$\mathrm{n}$} & \multicolumn{2}{|c|}{ Questionnaires } & \multicolumn{2}{|c|}{ Accelerometers } & \multirow{2}{*}{$\begin{array}{l}\text { Paired } \\
\text { t-test } \\
\text { p-value }\end{array}$} & \multicolumn{2}{|c|}{$\begin{array}{c}\text { Correlation } \\
\text { coefficient }\end{array}$} \\
\hline & & & Mean & SD & Mean & SD & & Pearson & p-value \\
\hline Number of days & Finland & 47 & 4.3 & 2.0 & 2.5 & 2.5 & $<0.001$ & 0.22 & 0.14 \\
\hline of $60 \mathrm{~min}$ of & Iceland & 52 & 4.0 & 1.9 & 2.9 & 2.3 & 0.002 & 0.42 & 0.002 \\
\hline MVPA (> 2000 & Norway & 59 & 4.0 & 1.6 & 2.5 & 2.1 & $<0.001$ & 0.56 & $<0.001$ \\
\hline$(\mathrm{cpm})[\mathrm{d} /$ week $]$ & All & 158 & 4.1 & 1.8 & 2.7 & 2.3 & $<0.001$ & 0.38 & $<0.001$ \\
\hline
\end{tabular}

Table 34. MVPA total time in adolescents Total time weekly of moderate physical activity in hours per week. P-values for comparison of questionnaires and accelerometers means by paired $t$-test and $p$-values for correlation coefficients are shown

\begin{tabular}{|c|c|c|c|c|c|c|c|c|c|}
\hline \multirow[t]{2}{*}{$\begin{array}{l}\text { Q1b } \\
(2000 \mathrm{cpm})\end{array}$} & & \multirow[b]{2}{*}{$\mathbf{n}$} & \multicolumn{2}{|c|}{ Questionnaires } & \multicolumn{2}{|c|}{ Accelerometers } & \multirow{2}{*}{$\begin{array}{r}\text { Paired t- } \\
\text { test } \\
\text { p-value }\end{array}$} & \multicolumn{2}{|c|}{$\begin{array}{r}\text { Correlation coeffi- } \\
\text { cient }\end{array}$} \\
\hline & & & Mean & SD & Mean & SD & & Pearson & p-value \\
\hline Total time in & Finland & 47 & 8.7 & 4.9 & 5.9 & 3.4 & $<0.001$ & 0.32 & 0.03 \\
\hline MVPA & Iceland & 52 & 7.5 & 3.6 & 6.8 & 3.3 & 0.22 & 0.40 & 0.003 \\
\hline (>2000 cpm) & Norway & 59 & 8.4 & 4.1 & 6.6 & 3.5 & $<0.001$ & 0.60 & $<0.001$ \\
\hline [hours/week] & All & 158 & 8.2 & 4.2 & 6.5 & 3.4 & $<0.001$ & 0.43 & $<0.001$ \\
\hline
\end{tabular}


Table 35. Number and portion (\%) reaching each of the two PA categories according to the Nordic recommendations (see Table 24) by the questionnaires (Ques) and accelerometers (Acc) in children. See Table 25 for definition of specificity and sensitivity

\begin{tabular}{lrrrrrrrrr} 
& \multicolumn{7}{c}{ A. Nordic recommendation of days per week } \\
& \multicolumn{1}{c}{ All countries } & \multicolumn{2}{c}{ Finland } & \multicolumn{2}{c}{ Iceland } & \multicolumn{2}{c}{ Norway } \\
PAC & Ques & Acc & Ques & Acc & Ques & Acc & Ques & Acc \\
\hline 0 & 4 & 38 & 2 & 14 & 2 & 10 & 0 & 14 \\
& $3 \%$ & $24 \%$ & $4 \%$ & $30 \%$ & $4 \%$ & $19 \%$ & $0 \%$ & $24 \%$ \\
1 & 131 & 110 & 34 & 28 & 44 & 39 & 53 & 43 \\
& $83 \%$ & $70 \%$ & $72 \%$ & $60 \%$ & $85 \%$ & $75 \%$ & $90 \%$ & $73 \%$ \\
2 & 23 & 10 & 11 & 5 & 6 & 3 & 6 & 2 \\
& $15 \%$ & $6 \%$ & $23 \%$ & $11 \%$ & $12 \%$ & $6 \%$ & $10 \%$ & $3 \%$ \\
All & 158 & 158 & 47 & 47 & 52 & 52 & 59 & 59 \\
& $100 \%$ & $100 \%$ & $100 \%$ & $100 \%$ & $100 \%$ & $100 \%$ & $100 \%$ & $100 \%$ \\
Specificity & $87 \%$ & & $76 \%$ & & $90 \%$ & & $93 \%$ & \\
Sensitivity & $40 \%$ & & $20 \%$ & & $33 \%$ & & $100 \%$ & \\
Not meeting recommendations & $85 \%$ & $94 \%$ & $77 \%$ & $89 \%$ & $88 \%$ & $94 \%$ & $90 \%$ & $97 \%$ \\
Meeting recommendations & $15 \%$ & $6 \%$ & $23 \%$ & $11 \%$ & $12 \%$ & $6 \%$ & $10 \%$ & $3 \%$ \\
\hline
\end{tabular}

\begin{tabular}{rrrrrrrr}
\multicolumn{7}{c}{ B. Nordic recommendation of hours per week } \\
All countries & \multicolumn{2}{c}{$\begin{array}{c}\text { Finland } \\
\text { Ques }\end{array}$} & \multicolumn{1}{c}{ Acc } & \multicolumn{1}{c}{ Icland } & \multicolumn{2}{c}{ Norway } \\
Ques & Acc & Ques & Acc & Ques & Acc \\
\hline 0 & 0 & 0 & 0 & 0 & 0 & 0 & 0 \\
$0 \%$ & $0 \%$ & $0 \%$ & $0 \%$ & $0 \%$ & $0 \%$ & $0 \%$ & $0 \%$ \\
62 & 95 & 19 & 32 & 21 & 29 & 22 & 34 \\
$39 \%$ & $60 \%$ & $40 \%$ & $68 \%$ & $40 \%$ & $56 \%$ & $37 \%$ & $58 \%$ \\
96 & 63 & 28 & 15 & 31 & 23 & 37 & 25 \\
$61 \%$ & $40 \%$ & $60 \%$ & $32 \%$ & $60 \%$ & $44 \%$ & $63 \%$ & $42 \%$ \\
158 & 158 & 47 & 47 & 52 & 52 & 59 & 59 \\
$100 \%$ & $100 \%$ & $100 \%$ & $100 \%$ & $100 \%$ & $100 \%$ & $100 \%$ & $100 \%$ \\
$52 \%$ & & $44 \%$ & & $59 \%$ & & $53 \%$ & \\
$79 \%$ & & $67 \%$ & & $83 \%$ & & $84 \%$ & \\
$39 \%$ & $60 \%$ & $40 \%$ & $68 \%$ & $40 \%$ & $56 \%$ & $37 \%$ & $58 \%$ \\
$61 \%$ & $40 \%$ & $60 \%$ & $32 \%$ & $60 \%$ & $44 \%$ & $63 \%$ & $42 \%$ \\
\hline
\end{tabular}


Table 36. Sedentary time in children. Sedentary activity ( $<100 \mathrm{cpm}$ for at least $10 \mathrm{~min}$ at a time). P-values for comparison of questionnaires and accelerometers means by paired t-test and $p$ values for correlation coefficients are shown

\begin{tabular}{|c|c|c|c|c|c|c|c|c|c|}
\hline \multirow[t]{2}{*}{$\begin{array}{l}\text { Q2 }(a+b) \\
(<100 \mathrm{cpm})\end{array}$} & & \multirow[b]{2}{*}{$\mathbf{n}$} & \multicolumn{2}{|c|}{ Questionnaires } & \multicolumn{2}{|c|}{$\begin{array}{l}\text { Accelerome- } \\
\text { ters }\end{array}$} & \multirow{2}{*}{$\begin{array}{l}\text { Paired } \\
\text { t-test } \\
\text { p-value }\end{array}$} & \multicolumn{2}{|c|}{$\begin{array}{l}\text { Correlation } \\
\text { coefficient }\end{array}$} \\
\hline & & & Mean & SD & Mean & SD & & $\begin{array}{l}\text { Pear- } \\
\text { son }\end{array}$ & $\begin{array}{l}p- \\
\text { value }\end{array}$ \\
\hline \multirow{2}{*}{$\begin{array}{l}\text { Sedentary time } \\
(<100 \mathrm{cpm})\end{array}$} & Finland & 47 & 1.7 & 0.7 & 2.1 & 0.8 & 0.002 & 0.40 & 0.006 \\
\hline & Iceland & 52 & 2.1 & 1.3 & 3.9 & 2.2 & $<0.001$ & 0.09 & 0.54 \\
\hline compared to TV & Norway & 58 & 1.7 & 1.0 & 2.3 & 1.0 & $<0.001$ & 0.31 & 0.02 \\
\hline $\begin{array}{l}\text { and computer } \\
\text { time [hours/day] }\end{array}$ & All & 157 & 1.8 & 1.1 & 2.8 & 1.7 & $<0.001$ & 0.23 & 0.005 \\
\hline
\end{tabular}

The last question in the questionnaires asked about the general leisuretime activity level of the respondent. Although this question is not able to identify in the same way as the other questions if recommendations are reached, it shows good correlation with all the accelerometer variables that were used above and also with total accelerometers counts, except for the sedentary variable (table 37 ).

Table 37. Correlations of general leisure-time activity level (Question 3$)^{7}$ with selected accelerometer variables in children

\begin{tabular}{lrrr}
\hline Accelerometer variable & $\begin{array}{r}\text { Pearson correla- } \\
\text { tion coefficient }\end{array}$ & p-value & $\mathbf{n}$ \\
\hline Total counts [cpm] & 0.32 & $<0.001$ & 158 \\
Number of days 60 min of activity, moderate or more $(>2000 \mathrm{cpm})$ & 0.36 & $<0.001$ & 158 \\
Total time in moderate activity $(>2000 \mathrm{cpm})$ [hours/week] & 0.38 & $<0.001$ & 158 \\
Sedentary time $(<100 \mathrm{cpm})$ compared to TV and computer time & -0.15 & 0.06 & 158 \\
[hours/day] & & & \\
\hline
\end{tabular}

\subsubsection{Discussion}

Although generally there is a good agreement in the results between countries, there are some exceptions. For physical activity, the correlation between the questionnaires and the accelerometer data was comparable or even higher than in previous studies. However, the correlation

${ }^{7}$ (Question 3 (classification of leisure-time physical activity)) Interviewer: Choose one of the following descriptions that best fits your child's leisure time activity during the last 7 days. (1) Reading, watching TV or other sedentary activity. (2) Walking, cycling, or other forms of light exercise that lasted for at least 4 hours during the last 7 days. Include walking or cycling to and from school, active recreation, etc. (such as skateboarding or rollerblading) (3) Participation in recreational sports (such as football or swimming), active games, etc. (such as tag), where the duration of activity lasted for at least 4 hours in total during the last 7 days. (4) Participation in hard training or sports competitions, regularly several times during the last 7 days. 
between the questionnaires and the accelerometer data for sedentary behaviour was weaker and not significant in adolescents which may indicate that TV and computer time is not a good indicator of total sedentary time. Thus the objective measurements include other episodes of sedentary time than just TV and computer time.

Overall, the indicator questions seem to over-estimate considerably physical activity and under-estimates sedentary behaviour, as measured by the more objective method. It should be recognized that accelerometers will underestimate certain types of physical activity like bicycle riding and they do not include water activities like swimming. Crosscountry skiing will also underestimate PA and it may bias the accelerometer data in Norway during the validation study. Thus, accelerometers will under-estimate true PA to some extent. On the other hand, self reported data is biased by several personal factors that are believed to have the tendency to over-estimate true PA. It should be realized that physical activity recommendations are mostly based on research that show associations between self-reported data and health indicators. Thus the recommendations may be more applicable to self-reported data but not to accelerometer data, i.e. if self-reported questionnaires generally over-estimate physical activity then that may to some extent be reflected in the recommendations. However, the accelerometer data is an objective measurement of physical activity and is believed to represents more true physical activities of the subjects. Thus, the validation was conducted by examining the correlation between the indicators questions and accelerometer data. However, more studies are needed to understand the discrepancy between self-reported data and data collected with objective methods like accelerometers. More knowledge is obtained by current master students at the University of Iceland.

The Nordic nutrition recommendation (2004) states that minimum amount of physical activity should be reached every day (30 min daily of moderate physical activity). The recommendation in the US, published 2007 (Haskell et al.., 2007), also used daily recommendations. However, the recommendations in the US (2008) used weekly amounts, i.e. 2,5 h of moderate PA or 1,25 h vigorous PA. Recent publication of physical activity recommendations in Canada also uses weekly targets (http://www. csep.ca/english/view.asp? $\mathrm{x}=804$ ). Both modes of reaching recommended level of PA (number of days per week and accumulated hours per week) were included in the current validation study and analysed accordingly (version $\mathrm{A}$ of the questionnaires). The modes show similar validity when compared with accelerometer data. As expected, accumulated hours of PA in a week indicate much higher proportion of subjects reaching the rec- 
ommendations. Many of the questionnaires, like IPAQ, that have been used to study proportion of populations reaching recommended level of PA, have been used to estimate weekly accumulated PA. From the above, it is thus suggested that the Nordic monitoring system should use only the weekly accumulation of PA mode of questions (version B of the questionnaire). By using just one mode of reaching recommendation will make the monitoring system less confusing and in line with recent developments of recommendations.

\subsubsection{Conclusion}

The validation study shows that the physical activity questions work as intended in all three age groups and reflects the objectively measured levels of physical activity. The NPAQ questionnaires are much shorter and easier to comprehend than more extensive questionnaires like IPAQ. Therefore, they are much more efficient and convenient to use in large scale monitoring surveys and when it is needed to incorporate PA monitoring into ongoing surveys on other issues. We recommend using the version B of the current questionnaires for future monitoring of physical activity in the Nordic countries. The data processing can easily adopt future developments in the recommendation regarding weekly accumulated physical activity and differences in the recommendations between countries. 


\section{Indicators - which results do they provide?}

The primary aim of the Nordic Monitoring project part 2 has been to test the feasibility and the validity of the suggested indicators of diet and physical activity. Besides from the validation results in the previous chapters, the results from the telephone surveys on diet conducted in Iceland and Denmark as well as results from the telephone surveys on physical activity conducted in Iceland, Norway and Finland are shown separately in the following sections.

\subsection{Which results can the dietary indicators provide?}

In the following results on dietary indicators are shown to give an overview of what the future data can provide. Data from Denmark is shown, as the survey covered all three age groups; children, adolescents and adults.

In the future monitoring it is possible to show results on basis on age groups, sex, educational groups, household and urbanization, but the focus in the following is on age groups as dividing into other groups will result in too small groups, as the validation study comprises less than a third of the numbers of participants in the future monitoring.

\subsubsection{Denmark}

The results are based on data from the telephone interviews conducted among 788 participants. 
Table 38. Frequency per week in intake of different foods in Danish children, adolescents and adults (NFFQ, $n=788$ )

\begin{tabular}{|c|c|c|c|c|c|c|}
\hline \multirow{3}{*}{$\begin{array}{l}\text { Age group } \\
n\end{array}$} & \multirow{2}{*}{\multicolumn{2}{|c|}{$\begin{array}{c}7-12 y \\
267\end{array}$}} & \multirow{2}{*}{\multicolumn{2}{|c|}{$\begin{array}{c}13-17 y \\
245\end{array}$}} & \multirow{2}{*}{\multicolumn{2}{|c|}{$\begin{array}{c}18-65 y \\
276\end{array}$}} \\
\hline & & & & & & \\
\hline & Mean & SD & Mean & SD & Mean & SD \\
\hline Rye bread, slices & 14.6 & 6.7 & 14.7 & 10.2 & 16.0 & 10.4 \\
\hline Wholemeal bread, slices & 6.7 & 7.1 & 9.4 & 9.1 & 6.9 & 7.8 \\
\hline Wheat bread, slices & 4.6 & 6.3 & 5.9 & 7.4 & 3.9 & 7.0 \\
\hline Vegetables & 9.6 & 5.9 & 8.8 & 5.9 & 9.1 & 6.2 \\
\hline Fruits & 13.2 & 6.9 & 13.7 & 9.1 & 13.2 & 9.3 \\
\hline Pommes frites, fried potatoes & 0.7 & 0.7 & 1.0 & 1.5 & 0.8 & 1.6 \\
\hline Fish & 2.0 & 1.8 & 1.8 & 2.7 & 2.4 & 2.8 \\
\hline Sausages & 0.3 & 0.4 & 0.3 & 0.5 & 0.3 & 0.6 \\
\hline Chocolate and candy & 2.5 & 3.0 & 3.1 & 2.9 & 3.5 & 5.0 \\
\hline Cookies and cakes & 2.0 & 2.1 & 1.9 & 2.8 & 1.6 & 1.6 \\
\hline Fulfat cheese & 2.0 & 2.9 & 1.9 & 2.9 & 3.5 & 3.5 \\
\hline Soft drinks, light & 1.8 & 3.6 & 2.6 & 4.8 & 2.6 & 5.5 \\
\hline Soft drinks, sugar sweetened & 1.7 & 2.8 & 2.2 & 3.1 & 1.7 & 3.6 \\
\hline Fruit, vegetable juice & 2.4 & 2.8 & 3.2 & 3.9 & 2.9 & 4.4 \\
\hline Water & 22.9 & 6.8 & 23.7 & 6.8 & 22.9 & 7.8 \\
\hline Milk & 11.4 & 7.7 & 10.5 & 9.2 & 5.6 & 7.1 \\
\hline
\end{tabular}

In Denmark, the weekly consumption of bread slices was approximately 25 slices, primarily rye bread and wholemeal bread. The frequency of fruits and vegetables was approximately 9 times per week for vegetables and 13 times per week for fruits corresponding to in total 3.1 times per day. Fried potatoes and sausages were eaten seldom. Soft drinks were consumed most frequently among adolescents, whereas milk is consumed most frequently among children. Surprisingly chocolate and candy were consumed most frequently among adults whereas cookies and cakes were consumed most often among children. 
Figure 1. Average frequency per week in intake of different foods in Danish children, adolescents and adults

Frequency of foods among children, adolescents and adults $(n=788)$

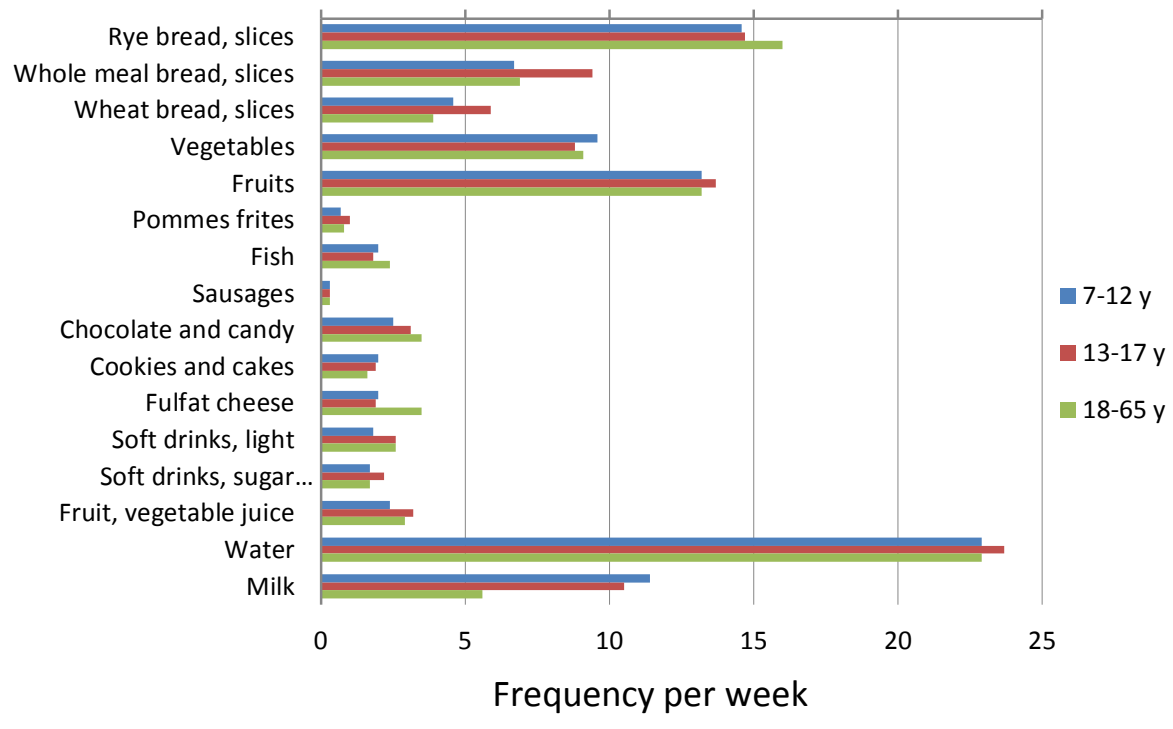

Table 39. Frequency per week in intake of foods in Danish adults (NFFQ, $n=276$ )

\begin{tabular}{lrrrrrr}
\hline Age group & $\mathbf{1 8 - 2 9} \mathbf{y}$ & & $\mathbf{3 0 - 4 9} \mathbf{y}$ & & $\mathbf{5 0 - 6 5} \mathbf{y}$ \\
$\mathbf{n}$ & $\mathbf{4 3}$ & & $\mathbf{1 2 1}$ & & $\mathbf{1 1 2}$ & \\
& Mean & SD & Mean & SD & Mean & SD \\
\hline Rye bread, slices & 19.5 & 16 & 15.4 & 8.9 & 15.4 & 8.9 \\
Wholemeal bread, slices & 7.9 & 9.2 & 6.7 & 7.7 & 6.7 & 7.4 \\
Wheat bread, slices & 6.7 & 9.1 & 3.3 & 7.1 & 3.4 & 5.8 \\
Vegetables & 8.5 & 5.9 & 9.2 & 6.4 & 9.4 & 6.1 \\
Fruits & 12.5 & 10.7 & 12.4 & 7.9 & 14.2 & 9.9 \\
Pommes frites, fried potatoes & 1.1 & 0.8 & 1.1 & 2.3 & 0.4 & 0.5 \\
Fish & 2.0 & 2.0 & 2.4 & 3.1 & 2.6 & 2.7 \\
Sausages & 0.3 & 0.4 & 0.3 & 0.4 & 0.3 & 0.7 \\
Chocolate and candy & 5.9 & 8.1 & 3.1 & 3.1 & 3.1 & 4.8 \\
Cookies and cakes & 1.4 & 1.3 & 1.7 & 1.6 & 1.6 & 1.7 \\
Full fat cheese & 1.3 & 2.4 & 3.4 & 3.3 & 4.5 & 3.7 \\
Soft drinks, light & 2.0 & 3.7 & 2.8 & 5.5 & 2.6 & 6.1 \\
Soft drinks, sugar sweetened & 3.0 & 4.8 & 1.6 & 3.8 & 1.2 & 2.6 \\
Fruit, vegetable juice & 4.2 & 6.4 & 2.9 & 4.3 & 2.5 & 3.4 \\
Water & 22.8 & 8.5 & 23.3 & 7.2 & 22.5 & 8.2 \\
Milk & 7.8 & 7.2 & 5.8 & 7.2 & 4.6 & 6.8 \\
\hline
\end{tabular}

Among adults, rye bread was eaten more frequently than wholemeal or wheat bread. Fruits were eaten more frequently than vegetables and the 50-65 y old ate more often vegetables and fruits than the 18-29 y old. Fish was eaten approximately twice a week in all three age groups. 
Figure 2. Average frequency per week in intake of different foods in Danish adults

\section{Frequency of foods among adults $(n=276)$}

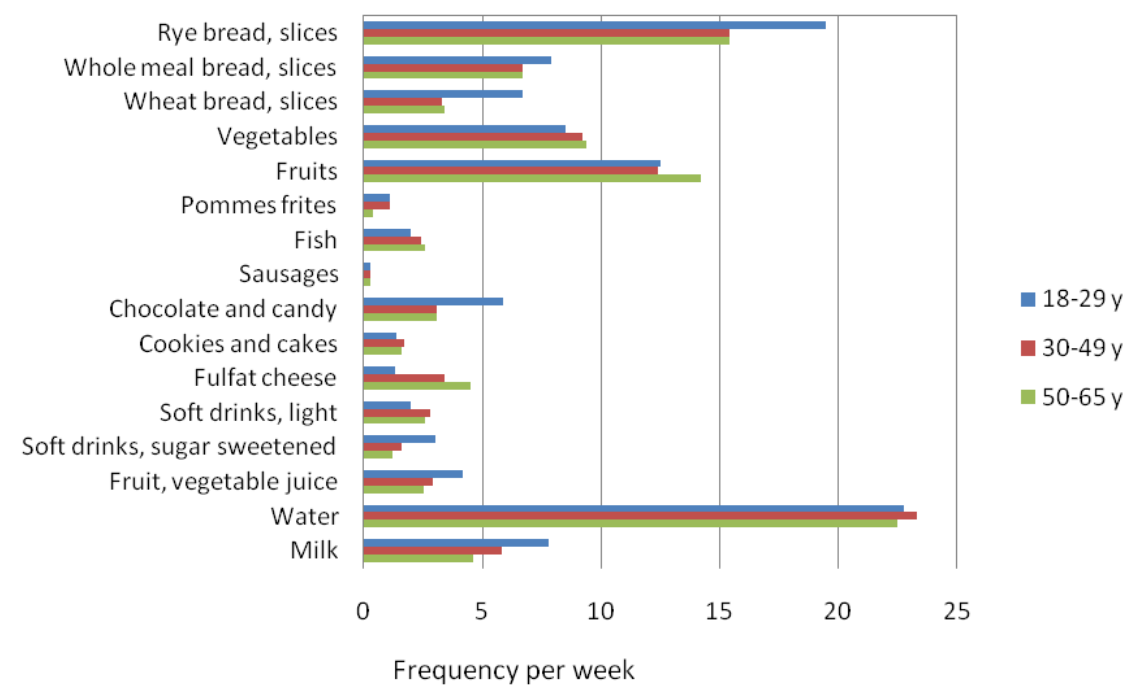

Table 40. Major type of fat used on bread in Danish children, adolescents and adults ( $n=788)$

\begin{tabular}{lrrr}
\hline Age group & $\mathbf{7 - 1 2} \mathbf{y}$ & $\mathbf{1 3 - 1 7} \mathbf{y}$ & $\mathbf{1 8 - 6 5} \mathbf{y}$ \\
$\mathbf{n}$ & $\mathbf{2 6 7}$ & $\mathbf{2 4 5}$ & $\mathbf{2 7 6}$ \\
& & Percent (\%) & \\
\hline Butter & & 11.0 & 17.4 \\
Butter/oil spread & 11.2 & 63.7 & 50.7 \\
Table margarine (60-80\% fat) & 63.7 & 2.4 & 0.7 \\
Margarine (<40\% fat) & 4.1 & 5.3 & 4.7 \\
Margarine (<40\% fat) with added phytosterols & 6.7 & 1.2 & 1.1 \\
Margarine (70-80\% fat) & 2.2 & 0 & 0.4 \\
Fat (pork fat, duck fat) & 0 & 0 & 1.1 \\
Do not use fat on bread & 12.0 & 16.3 & 23.9 \\
\hline
\end{tabular}

There was a higher proportion of users of butter among adults compared to children and adolescents. In all age groups more participants consumed butter/oil spread followed by butter. The adults had a higher proportion of non users of fat on bread than children and adolescents. 


\begin{tabular}{lrrr} 
Table 41. Major type of fat used on bread in Danish adults ( $\mathbf{n = 2 7 6 )}$ & & \\
\hline Age group & $\mathbf{1 8 - 2 9} \mathbf{y}$ & $\mathbf{3 0 - 4 9} \mathbf{y}$ & $\mathbf{5 0 - 6 5} \mathbf{y}$ \\
$\mathbf{n}$ & $\mathbf{4 3}$ & $\mathbf{1 2 1}$ & $\mathbf{1 1 2}$ \\
& & Percent (\%) & \\
\hline Butter & 9.3 & 18.2 & 19.6 \\
Butter/oil spread & 74.4 & 49.6 & 42.9 \\
Table margarine (60-80\% fat) & 0 & 0.8 & 0.9 \\
Margarine (<40\%fat) & 2.3 & 3.3 & 7.1 \\
Margarine (<40\% fat) with added phytosterols & 0 & 0.8 & 1.8 \\
Margarine (70-80\% fat) & 0 & 0.8 & 0 \\
Fat (pork fat, duck fat) & 2.3 & 0.8 & 0.9 \\
Do not use fat on bread & 11.6 & 25.6 & 26.8 \\
\hline
\end{tabular}

There was a higher proportion of butter users among the 50-65 y old and a high proportion of non users among the 30-65 y old compared to the 18-29 year old.

Table 42. Use of fat in cooking among Danish children, adolescents and adults $(\mathbf{n}=788)$

\begin{tabular}{lrrr}
\hline Age group & $\mathbf{7 - 1 2} \mathbf{y}$ & $\mathbf{1 3 - 1 7} \mathbf{y}$ & $\mathbf{1 8 - 6 5} \mathbf{y}$ \\
$\mathbf{n}$ & $\mathbf{2 6 7}$ & $\mathbf{2 4 5}$ & $\mathbf{2 7 6}$ \\
& & Percent (\%) & \\
\hline Butter & & 2.0 & 2.5 \\
Butter/oilspread & 1.1 & 1.2 & 2.9 \\
Margarine for frying or baking (70-80\% fat) & 3.4 & 11.8 & 10.9 \\
Table margarine (60-80\% fat) & 9.4 & 1.2 & 1.1 \\
Fluid margarine & 2.2 & 30.6 & 25.7 \\
Oil & 27.3 & 52.7 & 55.4 \\
A mix of oil and butter or butter/oilspread & 55.8 & 0.0 & 1.1 \\
Fat (porkfat, duckfat) & 0.4 & 0.4 & 0.0 \\
Do not use fat in cooking & 0.0 & 0.0 & 0.0 \\
Do not know & 0.4 & 0.0 & 0.4 \\
\hline
\end{tabular}

There was a high proportion of users of oil or fluid margarine in all three age groups. Hard margarine was used among approximately $10 \%$ of the participants. 
Table 43.Use of fat in cooking among Danish adults $(n=276)$

\begin{tabular}{lrrr}
\hline Age group & $\mathbf{1 8 - 2 9} \mathbf{y}$ & $\mathbf{3 0 - 4 9} \mathbf{y}$ & $\mathbf{5 0 - 6 5} \mathbf{y}$ \\
$\mathbf{n}$ & $\mathbf{4 3}$ & $\mathbf{1 2 1}$ & $\mathbf{1 1 2}$ \\
& & Percent (\%) & \\
\hline Butter & & 0.8 & 4.5 \\
Butter/oilspread & 2.3 & 2.5 & 0.9 \\
Margarine for frying or baking (70-80\% fat) & 9.3 & 9.9 & 9.8 \\
Table margarine (60-80\% fat) & 16.3 & 0.8 & 1.8 \\
Fluid margarine & 0.0 & 20.7 & 32.1 \\
Oil & 23.3 & 65.3 & 48.2 \\
A mix of oil and butter or butter/oilspread & 46.5 & 0.0 & 1.8 \\
Fat (porkfat, duckfat) & 2.3 & 0.0 & 0.0 \\
Do not use fat in cooking & 0.0 & 0.0 & 0.0 \\
Do not know & 0.0 & 0.0 & 0.9 \\
\hline
\end{tabular}

Especially the 30-49 y had a high proportion of users of vegetable oil, while especially the younger adults (18-29y) had a higher proportion of users of hard margarine and butter compared with the other age groups.

\subsubsection{Comparison of frequencies SE 2008 \& DK in adults}

In future monitoring data from five countries will be produced, thus enabling a comparison between the countries. As an example of such a comparison, the frequencies of foods and beverages per week for Danish adults 16-65 y are compared with frequencies per week from the latest Swedish monitoring of dietary indicators 2008 (Becker, 2009). The Swedish data are adjusted to comparable age group of 16-65 year. 
Table 44. Frequency per week in intake of foods in Swedish and Danish adults (FFQ)

\begin{tabular}{|c|c|c|c|c|}
\hline \multirow{4}{*}{$\begin{array}{l}\text { Age group } \\
n\end{array}$} & \multirow{2}{*}{\multicolumn{2}{|c|}{$\begin{array}{c}\text { Sweden } 2008 \\
16-65 y\end{array}$}} & \\
\hline & & & & \\
\hline & \multicolumn{2}{|c|}{805} & \multicolumn{2}{|c|}{369} \\
\hline & Mean & SD & Mean & SD \\
\hline Rye bread, slices & & & 16.0 & 10.4 \\
\hline Wholemeal bread, slices & $21.5^{*}$ & $21.2^{*}$ & 7.6 & 8.3 \\
\hline Wheat bread. Slices & & N.A. & 4.5 & 7.1 \\
\hline Vegetables & 8.8 & 5.8 & 9.1 & 6.2 \\
\hline Fruits & 8.6 & 6.5 & 13.4 & 9.4 \\
\hline Pommes frites, fried potatoes & 0.8 & 1.8 & 0.9 & 1.5 \\
\hline Fish & 1.4 & 1.1 & 2.3 & 2.9 \\
\hline Sausages & 0.8 & 1.0 & 0.3 & 0.6 \\
\hline Chocolate and candy & 2.0 & 3.0 & 3.6 & 4.7 \\
\hline Cookies and cakes & 1.5 & 2.5 & 1.6 & 1.6 \\
\hline Full fat cheese & 5.1 & 4.7 & 3.2 & 3.5 \\
\hline Soft drinks, light & $19^{x}$ & $41^{\text {म }}$ & 1.9 & 1.2 \\
\hline Soft drinks, sugar sweetened & & & 2.0 & 3.8 \\
\hline Fruit, vegetable juice & & N.A. & 3.0 & 4.1 \\
\hline Water & & N.A. & 23.3 & 7.6 \\
\hline Milk & & N.A. & 7.0 & 8.3 \\
\hline
\end{tabular}

*Due to different questions upon bread the results for bread are not exactly comparable

"The Swedish questionnaire has a general question on soft drinks (with or without added sugar)

As seen, differences between the countries occur, but due to different dietary habits comparison is difficult to some extent. The frequencies of intake of sausages and cheese were higher in Sweden than in Denmark, whereas the frequency of intake of fish, fruits and chocolate and candy was higher in Denmark. For other food groups the frequencies were quite similar.

\subsubsection{Dietary index}

On basis of the dietary indicators an overall index of healthy eating can be calculated. The same calculations and scores as used in Sweden has been used (0-2 points according to frequency, see table 45) for adults, children and adolescents. The Swedish index has values from 0-12 points and scores from 1-4 indicates a poor diet, scores from 5-8 indicates a medium nutritional quality of the diet, whereas scores 9-12 indicates a healthy diet. 
Table 45. Categorisation of answers from questionnaire (Becker. 2009. Indikatorer för bra matvanor. Resultat från intervjuundersökningar 2008)

\begin{tabular}{llccc}
\hline & Unit & $\mathbf{0 p}$ & $\mathbf{1} \mathbf{p}$ & $\mathbf{2} \mathbf{p}$ \\
\hline Fruit and vegetables & Times per day & $<3$ & $3-4$ & $\geq 5$ \\
Bread (wholemeal, rye) & Slices per day & $<1$ & $1-2$ & $\geq 3$ \\
Fish and seafood & Times per week & $<1$ & $1-2$ & $\geq 2$ \\
Candy, cakes, soft drinks, pommes frites & Times per week & $\geq 7$ & $3-6$ & $<3$ \\
Fat on bread & Type & $\geq 60 \%$ fat & $\leq 40 \%$ & - \\
Cheese & Times per week & $\geq 4$ & $1-3$ & $\leq 1$ \\
Sausages & Times per week & $>1$ & $\leq 1$ & - \\
\hline
\end{tabular}

In figure 3 and 4 , the scores for both children, adolescents and adults are shown. Approximately $70 \%$ of the population had a medium nutritional quality of their diet according to the dietary indicators. More females than males had scores indicating a healthy diet.

Figure 3. Dietary index among Danish male and female $(n=788)$

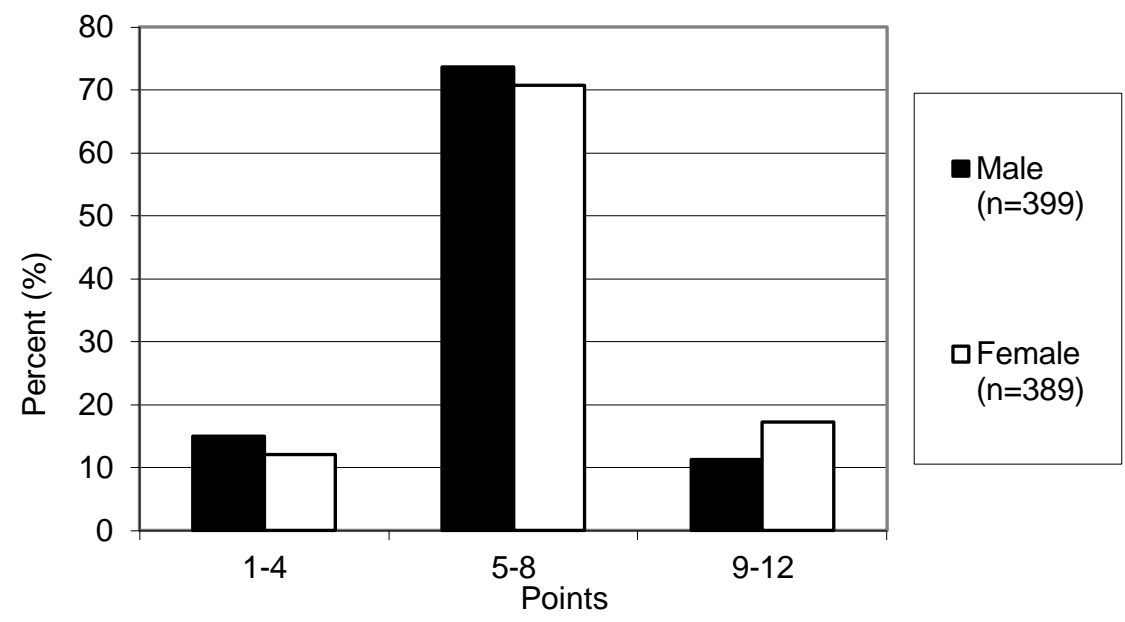

Figure 4. Dietary index among Danish children, adolescents and adults (n=788)

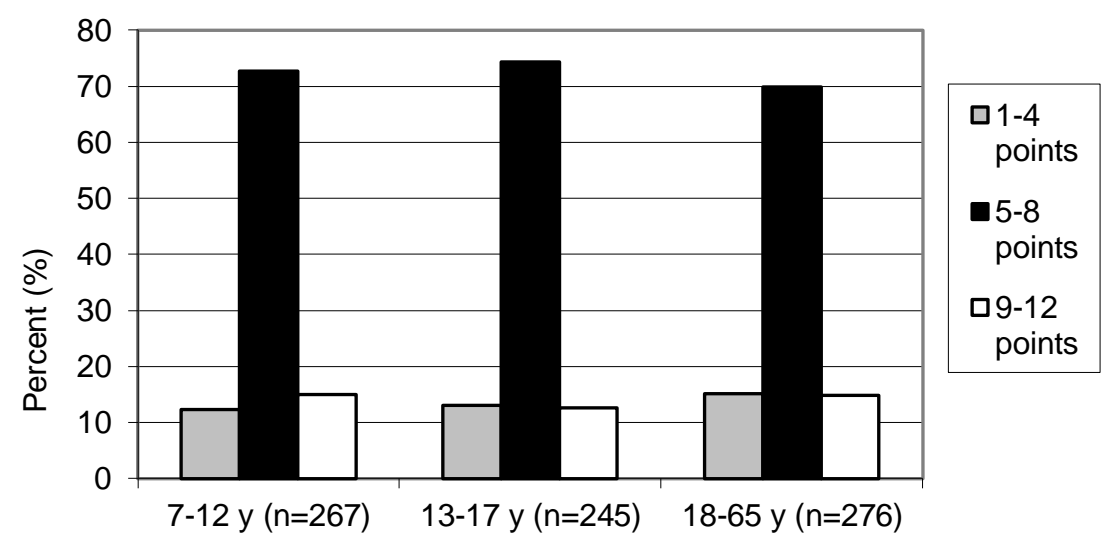




\section{Comparison of indices among adults in Sweden and DK}

As seen in figures below, a somewhat higher proportion of Swedes had poor dietary index compared to Danish adults. Both countries experienced more women than men with a healthy diet and the majority of the population with a medium nutritional quality of the diet.

Figure 5. Dietary index among Danish adults 16-65 y

Dietary index for Danish adults 16-65 y

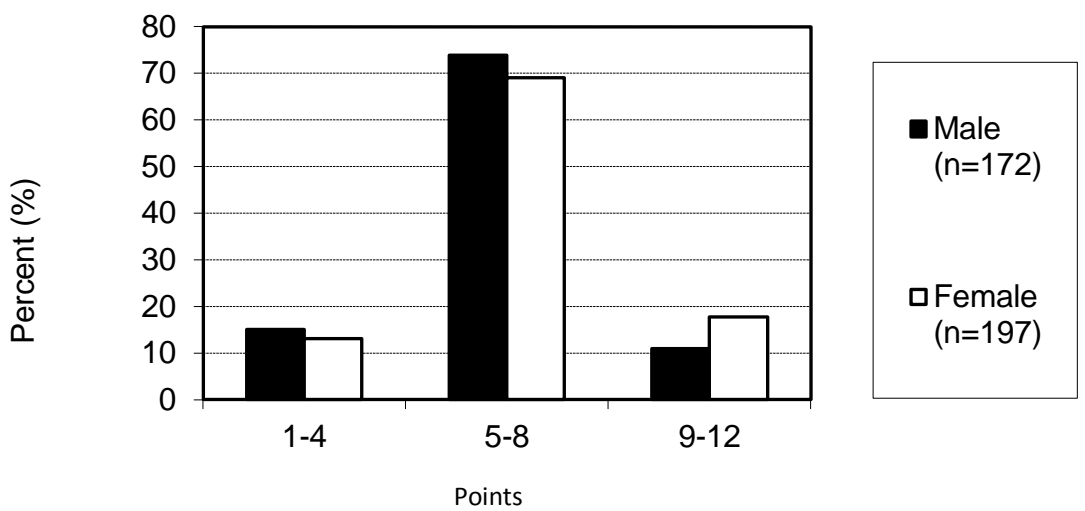

Figure 6. Dietary index among Swedish adults 16-65 y

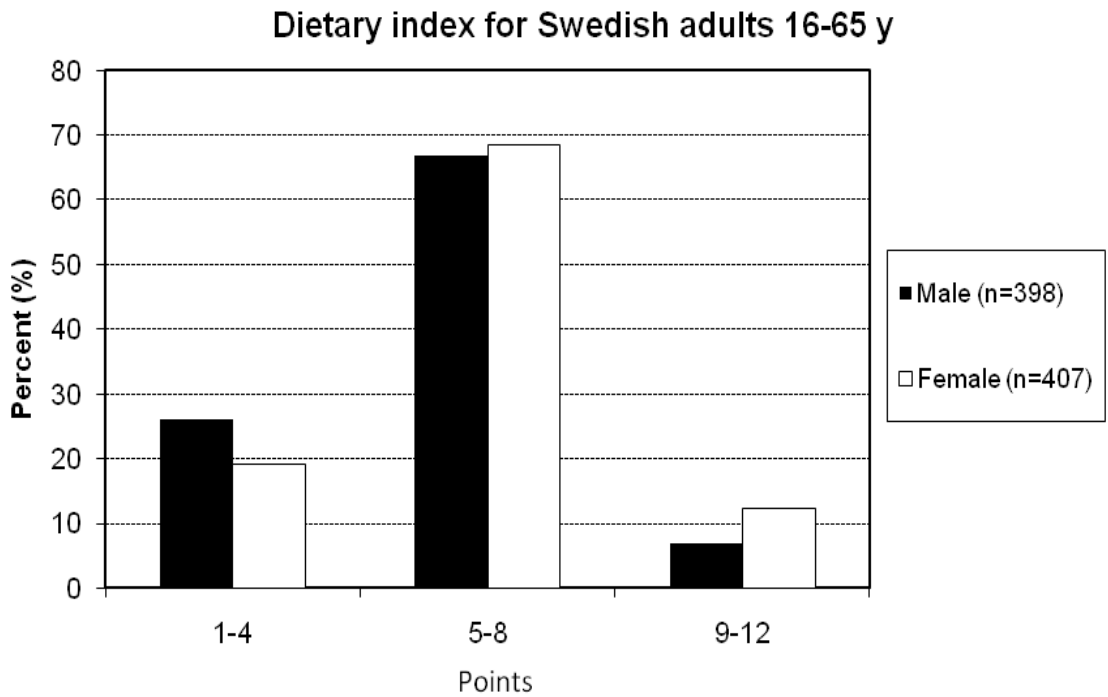




\subsection{Which results can the physical activity indicators provide?}

In the following results concerning physical activity an overview is shown of what the future data can provide (Fig 7-9). Data from Iceland, Finland and Norway are shown.

The indicators show how large portion of the population is classified into each physical activity category according to the suggested questions. These indicators measure weekly accumulated physical activity of moderate or vigorous intensity. The different physical activity categories reflect different modalities of reaching or not reaching the recommendation of physical activity. The indicators used are those suggested in this report to be used for a Nordic monitoring system.

Figure 7. Proportions of adults fulfilling different categories of recommendations of physical activity

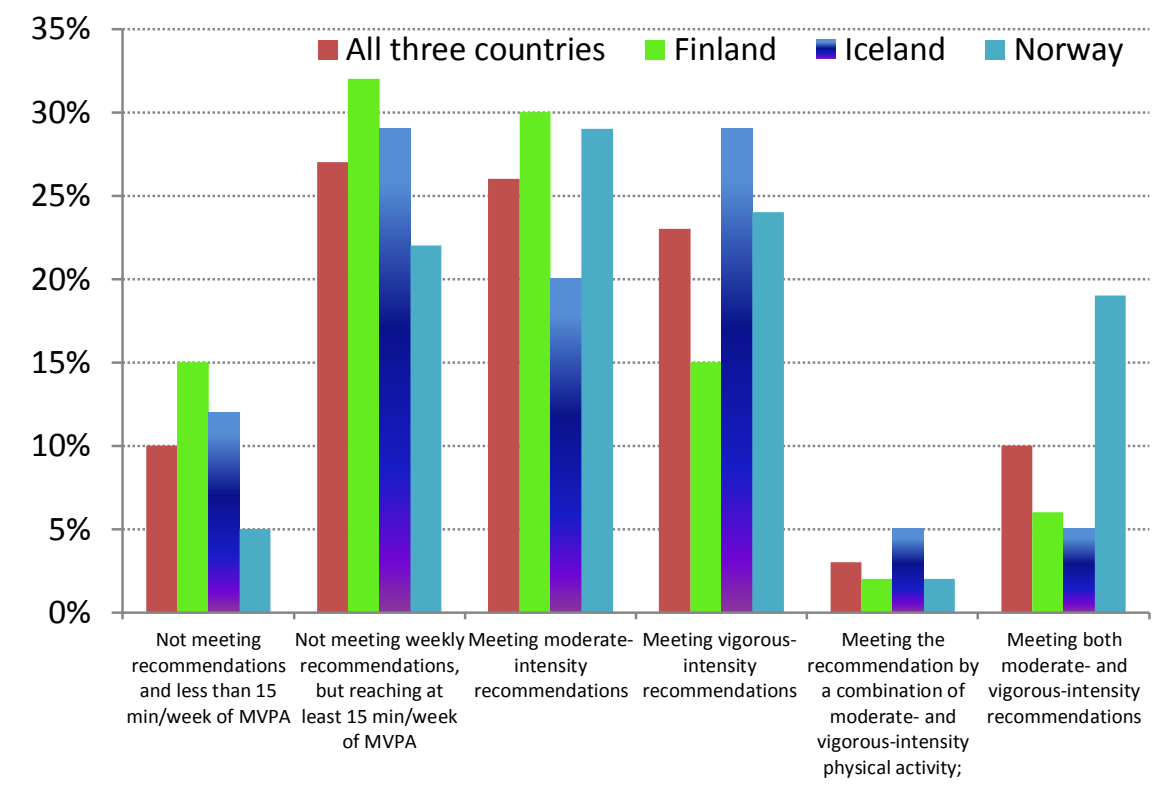


Figure 8. Proportions of adolescents fulfilling different categories of recommendations of physical activity

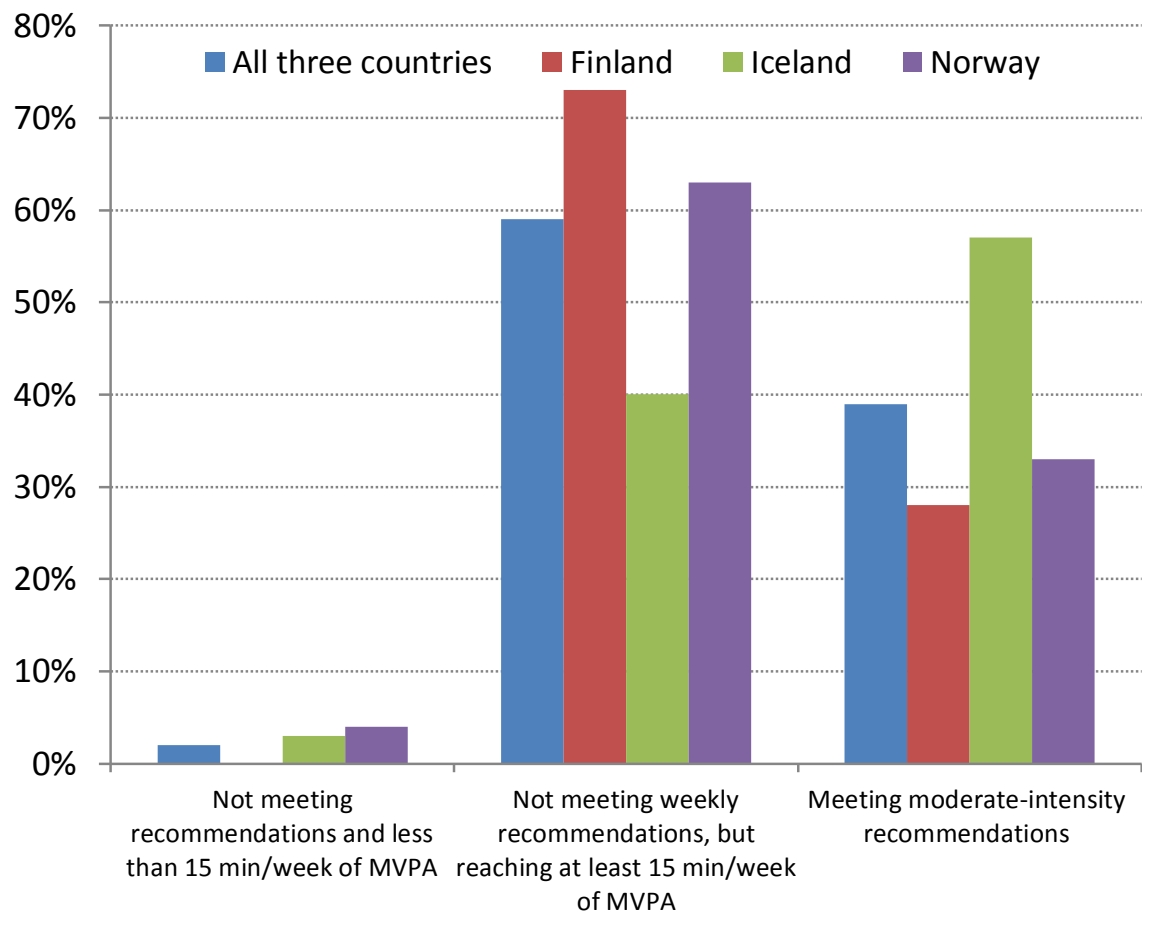

Figure 9. Proportions of children fulfiling different categories of recommendations of physical activity

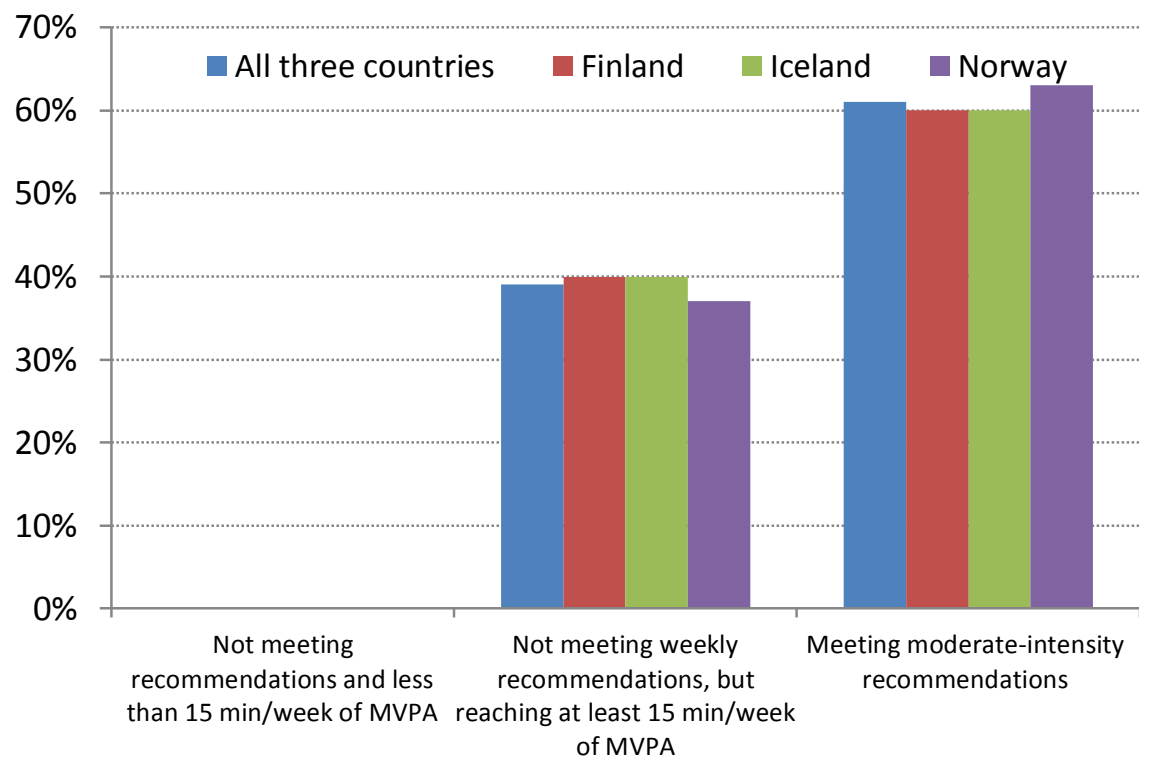


The children in all three countries had at least 15 minutes of moderate to vigorous physical activity per week. Most children were meeting moderate intensity recommendations. Among adolescents few participants did not meet recommendations of 15 minutes per week of moderate to vigorous physical activity and among adults this proportion was higher. Regarding how many adolescents and adults meeting other types of recommendations it was somewhat heterogeneous between countries, but it is not possible to state any firm values for fulfilling recommendations due to small samples in the validation studies.

\subsection{Results on height and weight}

In the validation studies participants were asked of self-reported height and weight. As data in the validation study was sampled as cluster samples or convenient samples, country specific data are not necessarily representative. Results from Denmark are shown as an example of which type of data the monitoring can provide.

Table 47. Average BMI $\left(\mathrm{kg} / \mathrm{m}^{2}\right)$ among participants (number in brackets)

\begin{tabular}{lrrr}
\hline & \multicolumn{2}{c}{ Denmark } & \\
& Children & Adolescents & Adults \\
\hline Male $(n)$ & $17.4(141)$ & $20.2(113)$ & $25.9(131)$ \\
Female $(n)$ & $16.4(112)$ & $19.8(120)$ & $24.4(143)$ \\
\hline
\end{tabular}

The average body mass index among males was slightly higher than among females in all three age groups.

Table $48 . \%$ of BMI categories adults

\begin{tabular}{lrr}
\hline & \multicolumn{2}{c}{ Denmark } \\
& Male ( $\mathbf{n = 1 3 1 )}$ & Female (143) \\
\hline Underweight & 2.3 & 2.8 \\
Normal weight & 47.3 & 62.9 \\
Overweight & 33.6 & 23.1 \\
Obese & 16.8 & 11.2 \\
\hline
\end{tabular}


In Denmark approximately $34 \%$ of males and $23 \%$ of females were overweight, which are slightly lower figures than in a recent report regarding public health in Denmark (Ekholm et al., 2005), showing 41 and 26\% respectively. Approximately $17 \%$ of males and $11 \%$ of women were obese and these figures are slightly higher for men than reported in Ekholm et al. (2005), where the figures are $12 \%$ among males and $11 \%$ among females. The figures in Ekholm et al. (2005) are also self reported. 



\section{References}

Andersen LF, Johansson L, Solvoll K (2002). Usefulness of a short food frequency questionnaire for screening of low intake of fruit and vegetable and for intake of fat. Eur J Publ Health 12: 208-213.

Becker W (2009). Indikatorer för bra matvanor. Resultat från intervjuundersökningar 2008. SLV Rapport 22-2009, National Food Administration, Sweden.

Craig CL, Marshall AL, Sjöström M, Bauman AE, Booth ML, Ainsworth BE, Pratt M, Ekelund U, Yngve A, Sallis JF, Oja P. Med Sci Sports Exerc. 2003 Aug; 35(8):1381-95.

Ekholm O, Kjøller M, Davidsen M, Hesse U, Eriksen L, Christensen AI, Grønbæk M (2005). Sundhed og sygelighed i Danmark - og udvikling siden 1987. Statens Institut for Folkesundhed.

Fagt S, Biltoft-Jensen, Matthiessen J, Groth MV, Christensen T, Trolle E (2008). Danskernes kostvaner 1995-2006. DTU Fødevareinstituttet.

Fagt S, Andersen LF, Anderssen SA, Becker W, Borodulin K, Fogelholm M, Groth MV, Gunnarsdottir I, Johansson G, Matthiessen J, Sveinsson T, Tammelin T, Thorgeirsdottir H, Valsta L, Trolle E (2009). Nordic monitoring on diet. physical activity and overweight. Part 1: Description of a common Nordic method for collecting representative data. National Food Institute. Technical University of Denmark.

Fogelholm M, Malmberg J, Suni J, Santtila M, Kyröläinen H, Mäntysaari M, Oja P (2006). International Physical Activity Questionnaire: Validity against fitness. Med Sci Sports Exerc. Apr 38(4):753-60.

Haskell WL, Lee IM, Pate RR, Powell KE, Blair SN, Franklin BA Macera CA, Heath GW, Thompson PD, Bauman A (2007). Physical activity and public health - Updated recommendation for adults from the American college of sports medicine and the American heart association. Circulation, 116(9): p. 1081-1093.

Haskell, W., Lee, M., Pate, R., Powell, K., Blair, S., Franklin, B., Macera, C., Heath, G., Thompson, P., \& Bauman, A. Physical activity and public health. Updated recommendation for adults from the American college of sports medicine and American heart association. Med. Sci. Sports Exerc. 2007, 39 (8), 1423-34.

Masson LF, MCNeill G, Tomany JO, Simpson JA, Peace HS, Wei L, Grubb D, BoltonSmith C. Statistical approaches for assessing the relative validity of a foodfrequency questionnaire: use of correlation coefficients and the kappa statistic. Public Health Nutrition 2003, 6 (3), 313-321.

Nordic Council of Ministers, Nordic nutrition recommendations. Integrationg nutrition and physical activity. 2004, Copenhagen: Nordic Council of Ministers.

Petkeviciene J, Simila M, Becker W, Kriaucioniene V, Valsta LM (2009). Validity and reproducibility of the NORBAGREEN food frequency questionnaire. Eur J Clin Nutr 63, 141-149.

Physical Activity Guidelines for Americans. U.S. Department of Health and Human Services. 2008. www.health.gov/paguidelines.

Saltin B, Grimby G. Physiological analysis of middle-aged and older former athletes. Comparison with still active athletes of the same ages. Circulation 1968; 38: 1104-15.

Sepp H, Ekelund U, Becker W (2004). Enkätfrågor om kost och fysisk aktivitet bland vuxna. SLV Rapport 21-2004, National Food Administration, Sweden. 
Stamatakis, E., M. Hamer and D.W. Dunstan (2011), Screen-Based Entertainment Time, All-Cause Mortality, and Cardiovascular Events Population-Based Study With Ongoing Mortality and Hospital Events Follow-Up. Journal of the American College of Cardiology 57(3): p. 292-299.

Troiano, R.P., D. Berrigan, K.W. Dodd, L.C. Masse, T. Tilert and M. McDowell (2008). Physical activity in the United States measured by accelerometer. Medicine and Science in Sports and Exercise 40(1): p. 181-188.

Vereecken CA\& Maes L (2003). A Belgian study on the reliability and relative validity of the Health Behaviour in School-Aged Children food-frequency questionnaire. Sep;6(6):581-8.

Watson JF, Collins CE, Sibbritt DW, Dibley MJ, Garg ML (2009). 37. Int J Behav Nutr Phys Act. Sep 11; 6: 62. 


\section{Sammenfatning}

Som led i den nordiske handlingsplan er det besluttet at udvikle et fælles nordisk monitoreringssystem, som kan måle udviklingen i befolkningens kostvaner, fysiske aktivitetsniveau samt overvægt.

Kravene til systemet er, at det skal være enkelt, gerne baseret på indikatorspørgsmål og samtidig ikke være for dyrt at gennemføre. Projektet består af tre faser. Første fase har beskrevet et monitoreringssystem baseret på repræsentative data, inklusiv beskrivelse af hvor mange deltagere, der skal være i hvert land, og hvorledes systemet kan implementeres i de nordiske lande. Anden fase af projektet er validering af monitoreringssystemet, hvad angår de målemetoder, der foreslås for kosten og fysisk aktivitet. Tredje fase er første indsamling af data i alle nordiske lande.

\section{Arbejdsgruppens medlemmer har været:}

- Lene Frost Andersen, Universitetet i Oslo, NO

- Sigmund Anderssen, Norges Idrætshøjskole, NO

- Ingibjörg Gunnarsdottir, Universitetet på Island \& LandspitaliUniversity Hospital, IS

- Thorarinn Sveinsson, Universitetet på Island, IS

- Holmfridur Thorgeirsdottir, Public Health Institute, IS

- Liisa Valsta \& Katja Bordulin, National Institute for health and Welfare, FI

- Tuija Tammelin, LIKES Research Center for Sport and Health Sciences, FI

- Wulf Becker, Statens Livsmedelsverk, SE

- Gunnar Johansson, Folkehälsoinstituttet, SE

- Margit V. Groth, Jeppe Matthiessen, Mette Rosenlund Sørensen, DTU Fødevareinstituttet, DK

- Sisse Fagt og Ellen Trolle (projektkoordinatorer) fra DTU Fødevareinstituttet, DK

Arbejdsgruppen har holdt 4 møder (2008-2009) og et møde i forbindelse med valideringsstudierne (2009). 
Øvrige forskere, som har deltaget i valideringsprojekterne har været:

- Elin Kolle, Norges Idrætshøjskole, NO

- Satu Helakorpi, National Institute for health and Welfare, FI

- Riitta Simonen, Finnish Institute of Occupational Health, FI

Nærværende rapport giver et kort beskrivelse af første del af projektet, men hovedfokus er på resultaterne fra anden fase, valideringsprojektet. Spørgsmål om kost blev validering blandt børn og unge på Island, mens både børn, unge og voksne deltog i valideringsprojektet i Danmark. Validering af spørgsmål på fysisk aktivitet blev foretaget blandt børn, unge og voksne i både Norge, Finland og Island.

Valideringsstudiet blev samfinansieret af NKMT og Nordic Innovation. Gennem Nordic Innovations fokusområde "Healthier choices for all" blev det desuden besluttet at inkludere yderligere et projekt $\mathrm{i}$ anden del af projektet. Dette var projektet "Network on Childhood Growth", som har til formål at koordinere og harmonisere centrale målinger vedr. børns sundhed og overvægt. Aktører indenfor området har gennem netværket udvekslet erfaringer og diskuteret, hvorledes den allerede eksisterende måling af børns sundhed, højde og vægt kan systematiseres.

En referencegruppe med bl.a. repræsentanter fra fødevareindustri og brancheorganisationer har været tilknyttet monitoreringsprojektets fase 2 .

\subsection{Hovedresultater og konklusion}

Indikatorerne for kost omfatter spørgsmål om antal spiste skiver brød, spørgsmål om hvor ofte frugt, grøntsager, pommes frites/stegte kartofler, fisk og skaldyr, pølse som hovedmåltid, slik og chokolade, fuldfed ost, sodavand og saft (med tilsat sukker eller light) samt frugt/grøntsagsjuice indtages. Desuden spørges til hvilken slag fedtstof der anvendes på brød og i madlavning. Indtaget af disse fødevarer er identificeret som indikatorer for indtaget af fedt, mættet fedt, kostfiber og tilsat sukker. Valideringsstudiet på kosten viser at indtagsfrekvenser af kostindikatorerne er positivt korreleret med estimeret indtag i gram fra referencemetoden (7 dages kostdagbog). Kostindikatorerne er desuden i stand til at rangordne individer acceptabelt i forhold til deres indtag af relevante makronæringsstoffer. Kostindikatorerne vil ikke være i stand til at måle befolkningens saltindtag. Analyser fra Danmark viser at indikatorspørgsmålene for frugt og grønt har en god evne til at detektere de personer, som ikke spiser tilstrækkeligt med frugt og grønt, mens evnen til 
at detektere de personer, som følger anbefalingen for frugt og grønt er lidt ringere. Tilsvarende analyser for Island er vanskelige at gennemføre. Overordnet virker indikatorspørgsmålene bedre for børn og voksne end blandt unge.

Spørgsmålene om fysisk aktivitet spørger til tid anvendt på moderat og hård aktivitet samt hård aktivitet al.ene. Desuden spørges til tid brugt på TV og computer. Spørgsmålene er valideret overfor accelerometer, som i nogen grad vil underestimere visse former for fysisk aktivitet (cykling/svømning). Overordnet viser valideringsstudiet at indikatorerne for fysisk aktivitet virker efter hensigten i alle tre aldersgrupper (børn, unge og voksne) og afspejler de objektivt målte niveauer af fysisk aktivitet.

Indikatorspørgsmålene vedrørende kost vil give informationer om, hvor ofte befolkningen spiser og drikker udvalgte fødevarer. Spørgsmålene om fysisk aktivitet vil vise intensitet og varighed af forskellige aktiviteter. Suppleret med oplysninger fra de nationale undersøgelser inden for kost og fysisk aktivitet, der allerede eksisterer, vil monitoreringen vise, hvorledes kosten, den fysiske aktivitet samt graden af overvægt udvikler sig i forhold til de mål og visioner, der er opstillet i den nordiske handlingsplan

De nordiske indikatorspørgsmål vil være et vigtigt redskab for interessenter i norden. Indikatorerne kan måle hvorledes udviklingen er i regionen inden for kost, fysisk aktivitet og overvægt. Desuden kan spørgsmålene bruges nationalt og lokalt i andre sammenhænge.

Netværket vedrørende børns sundhed består af repræsentanter for sundhedsmyndigheder og forskere indenfor børns vækst og sundhed. Følgende personer har deltaget:

- Bente Moe, Helsedirektoratet, NO

- Ragnhild Hovengen, FHI, NO

- Martin Handeland, SIV, NO

- Pétur B. Júlíusson, Haukeland University Hospital, NO

- Anton Lager og Petra Löfstedt, Swedish Nat Inst Publ Health, SE

- Max Petzold, NHV, SE

- Carl Erik Flodmark, Childhood Obesity Unit, Malmø, SE

- Anders Hjern, Social department, SE

- Agneta Sjoberg University of Gothenburg, SE

- Ragnheiður Erlendsdóttir, Centre for childhood; health services, IS

- Mika Gissler, Leo Dunkel, Paivi Maki, all THL, FI

- Lene Hammer Helmich, Research Centre for prevention \& health, DK

- Ellen Trolle, DTU Food, DK, Sisse Fagt, DTU Food, DK

- Lise Graversen og Carsten Obel, Aarhus Universitet, DK 
Netværket har holdt to møder og har præsenteret igangværende aktiviteter indenfor måling af børns vækst og sundhed. Netværket har søgt midler til at fortsætte arbejdet, men hidtil uden succes.

Monitoreringsprojektet har haft en referencegruppe bestående af følgende medlemmer: Steinar Høie, NHO Mat og Drikke, NO, Grethe Andersen, Danske Slagterier, DK; Karin Fisker, Landbrugsrådet, DK; Paula Virtanen, Polar Electro Oy, FI; Jyrki Eklund, Aino Active Oy, FI; Elisabet Rytter, Swedish Food Federation, SE; Ragnheidur Hedinsdottir, Federation of Icelandic Industries, IS; Kjersti Lillebø, SIFO, NO samt Ellen Trolle, Sisse Fagt og Carsten Obel, DK. Referencegruppen er blevet orienteret gennem e-mail kommunikation.

\subsection{Anbefalinger}

Arbejdsgruppen anbefaler at kostindikatorspørgsmålene (NFFQ) anvendes til den fremtidige monitorering af kosten i Norden, men data skal suppleres med viden om portionsstørrelser i norden ved tolkning af resultaterne og sammenligning på tværs af lande. Desuden skal resultaterne fra NFFQ suppleres med data fra nationale kostundersøgelser, idet NFFQ kun indikerer næringsstofniveauet i befolkningen og ikke i sig selv viser tal for indtaget af næringsstoffer.

Arbejdsgruppen anbefaler at indikatorerne for fysisk aktivitet anvendes for den fremtidige monitorering af fysisk aktivitet i norden. Det anbefales at bruge spørgsmålene om hvor mange timer pr. uge deltagerne er fysisk aktive.

\subsection{Fremtidige opgaver}

Netværket vedr. børns sundhed vil fortsætte og udvide netværket til at dække mere analystisk epidemiologiske og videnskabelige aspekter, hvis finansiering til dette kan skaffes.

Arbejdsgruppen for monitoreringsprojektet vil præsentere resultater for valideringsstudierne ved nationale og internationale konferencer. Det er desuden planlagt at projektdeltagerne skal publicere resultaterne fra valideringsstudiet på nationale hjemmesider for at sikre opmærksomhed om de validerede indikatorspørgsmål på både national og lokalt niveau. 


\section{Appendices}

Table A1. Examples of frequencies per week as measured by NFFQ and calculated from the food records (on basis of either eating occasion or servings), Denmark

\begin{tabular}{|c|c|c|c|c|}
\hline \multirow[t]{2}{*}{ Age group } & & $7-12 y$ & $13-17 y$ & $18-65 y$ \\
\hline & $\mathrm{n}$ & 201 & 151 & 180 \\
\hline \multirow[t]{3}{*}{ Rye bread* } & NFFQ & 14.6 & 14.5 & 16.0 \\
\hline & Eating occasion FR & 6.2 & 4.4 & 7.2 \\
\hline & Servings FR & 17.4 & 13.7 & 20.6 \\
\hline \multirow[t]{3}{*}{ Wholemeal bread* } & NFFQ & 6.7 & 8.9 & 6.6 \\
\hline & Eating occasion FR & 3.4 & 3.1 & 2.8 \\
\hline & Servings FR & 6.6 & 7.3 & 5.1 \\
\hline \multirow[t]{3}{*}{ Vegetables } & NFFQ & 10.1 & 8.9 & 9.6 \\
\hline & Eating occasion FR & 10.7 & 6.8 & 10.3 \\
\hline & Servings FR & 14.8 & 10.4 & 13.8 \\
\hline \multirow[t]{3}{*}{ Fruits } & NFFQ & 13.3 & 13.5 & 14.1 \\
\hline & Eating occasion FR & 9.5 & 7.8 & 11.1 \\
\hline & Servings FR & 12.0 & 11.1 & 15.9 \\
\hline \multirow[t]{3}{*}{ Cake } & NFFQ & 1.9 & 1.9 & 1.8 \\
\hline & Eating occasion FR & 2.7 & 2.2 & 3.3 \\
\hline & Servings FR & 6.2 & 4.9 & 6.4 \\
\hline \multirow[t]{3}{*}{ Candy } & NFFQ & 2.5 & 2.9 & 3.6 \\
\hline & Eating occasion FR & 3.5 & 3.6 & 4.0 \\
\hline & Servings FR & 5.0 & 6.0 & 6.8 \\
\hline \multirow[t]{3}{*}{ Water } & NFFQ & 23.1 & 23.4 & 22.6 \\
\hline & Eating occasion FR & 12.1 & 10.3 & 13.2 \\
\hline & Servings FR & 21.7 & 23.3 & 29.0 \\
\hline \multirow[t]{3}{*}{ Milk } & NFFQ & 11.1 & 10.7 & 5.5 \\
\hline & Eating occasion FR & 8.4 & 7.0 & 7.6 \\
\hline & Servings FR & 11.3 & 10.9 & 12.2 \\
\hline
\end{tabular}

*Frequencies counted as slices per week. If participants eat 2 slices of bread in a meal, this will be counted as 2 slices when counting servings and as 1 eating occasion when counting eating occasions. 
Table A2. Intake of fat (E\%) without alcohol from food record in relation to frequencies from NFFQ Denmark

\begin{tabular}{|c|c|c|c|c|c|c|c|c|c|c|c|c|c|c|c|c|c|c|}
\hline \multirow{4}{*}{ Age group } & \multicolumn{6}{|c|}{$7-12 y$} & \multicolumn{6}{|c|}{$13-17 y$} & \multicolumn{6}{|c|}{$18-65 y$} \\
\hline & \multirow{3}{*}{$\begin{array}{c}\text { Per month } \\
\begin{array}{r}0-3 \text { times } \\
\text { Mean }(n)\end{array}\end{array}$} & \multicolumn{4}{|c|}{201} & & \multicolumn{6}{|c|}{151} & \multicolumn{6}{|c|}{180} \\
\hline & & \multicolumn{2}{|c|}{ Per week } & \multicolumn{2}{|c|}{ Per day } & \multirow[b]{2}{*}{ p-value* } & \multirow{2}{*}{$\begin{array}{r}\text { Per month } \\
\begin{array}{r}\text { 0-3 times } \\
\text { Mean (n) }\end{array}\end{array}$} & \multicolumn{2}{|c|}{ Per week } & \multicolumn{2}{|c|}{ Per day } & \multirow[b]{2}{*}{$\begin{array}{r}\text { p- } \\
\text { value* }\end{array}$} & \multirow{2}{*}{$\begin{array}{c}\text { Per month } \\
\begin{array}{r}0-3 \text { times } \\
\text { Mean }(n)\end{array}\end{array}$} & \multicolumn{2}{|c|}{ Per week } & \multicolumn{2}{|c|}{ Per day } & \multirow[b]{2}{*}{ p-value* } \\
\hline & & $\begin{array}{l}1-2 \text { times } \\
\text { Mean }(n)\end{array}$ & $\begin{array}{l}3-6 \text { times } \\
\text { Mean }(n)\end{array}$ & $\begin{array}{l}1-2 \text { times } \\
\text { Mean }(n)\end{array}$ & $\begin{array}{r}3 \text { times } \\
\text { or more } \\
\text { Mean }(n)\end{array}$ & & & $\begin{array}{r}1-2 \text { times } \\
\text { Mean }(n)\end{array}$ & $\begin{array}{l}3-6 \text { times } \\
\text { Mean (n) }\end{array}$ & $\begin{array}{l}1-2 \text { times } \\
\text { Mean }(n)\end{array}$ & $\begin{array}{r}3 \text { times } \\
\text { or more } \\
\text { Mean }(n)\end{array}$ & & & $\begin{array}{l}1-2 \text { times } \\
\text { Mean }(n)\end{array}$ & $\begin{array}{l}3-6 \text { times } \\
\text { Mean }(n)\end{array}$ & $\begin{array}{l}1-2 \text { times } \\
\text { Mean }(n)\end{array}$ & $\begin{array}{c}3 \text { times } \\
\text { or more } \\
\text { Mean }(n)\end{array}$ & \\
\hline Rye bread, slices & $30,7(3)$ & $32,4(2)$ & $34,3(5)$ & $32,9(138)$ & $34,4(53)$ & 0.045 & $30.6(7)$ & $31,0(4)$ & $33.0(21)$ & $32.9(79)$ & $32,5(40)$ & 0.392 & $37.4(2)$ & 35,7 (9) & $33,2(4)$ & $33.9(104)$ & $35.4(61)$ & 0.094 \\
\hline Wholemeal bread, slices & $34.6(38)$ & $33.1(29)$ & $32.5(43)$ & $33.3(82)$ & $32.7(9)$ & 0.212 & $33.6(25)$ & $33.4(15)$ & $33.5(27)$ & $32.5(63)$ & $30.4(21)$ & 0.005 & $34.1(30)$ & 34.7 (37) & $34.4(30)$ & $34.4(72)$ & $35.8(11)$ & 0.364 \\
\hline Wheat bread, slices & $32.2(47)$ & $33.1(61)$ & $34.6(37)$ & $33.3(49)$ & $34.7(7)$ & 0.050 & $31.4(31)$ & $32.9(35)$ & $33.0(28)$ & $33.0(49)$ & $33.1(8)$ & 0.120 & $34.0(74)$ & $34.1(54)$ & $36.9(18)$ & $35.2(27)$ & $35.3(7)$ & 0.068 \\
\hline Vegetables & $33.2(2)$ & $33.6(12)$ & $35.0(23)$ & $33.1(147)$ & $32.5(17)$ & 0.038 & $35.4(5)$ & $33.9(14)$ & $33.6(13)$ & $32.4(106)$ & $30.6(8)$ & 0.020 & $35.3(3)$ & $39.4(12)$ & $34.6(28)$ & $34.3(124)$ & $32.3(13)$ & 0.004 \\
\hline Fruits & $39.8(1)$ & $35.3(4)$ & $35.0(19)$ & $33.5(131)$ & $31.8(46)$ & 0.001 & 35.7 (4) & $34.4(14)$ & $34.4(11)$ & $32.7(77)$ & $31.4(45)$ & 0.002 & $38.4(6)$ & $37.4(10)$ & $37.7(16)$ & $34.8(91)$ & $32.3(57)$ & $<0.001$ \\
\hline Pommes frites, fried potatoes & $33.4(139)$ & $33.3(54)$ & $32.1(8)$ & & - & 0.468 & $32.6(89)$ & $33.1(49)$ & $31.4(13)$ & & . & 0.396 & $34.2(129)$ & $35.5(47)$ & $31.0(2)$ & $36.0(1)$ & $31.5(1)$ & 0.105 \\
\hline Fish & $32.3(48)$ & $33.3(101)$ & $33.5(38)$ & $35.8(14)$ & - & 0.037 & $33.7(40)$ & $32.7(88)$ & $30.0(16)$ & $31.7(6)$ & $35.3(1)$ & 0.014 & $36.2(38)$ & $34.3(80)$ & $33.8(42)$ & $34.6(19)$ & $21.0(1)$ & 0.032 \\
\hline Sausages & $33.4(187)$ & 31.9 (14) & & & 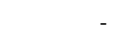 & 0.226 & $32.8(144)$ & $30.5(7)$ & & & - & 0.118 & $34.6(175)$ & $34.4(4)$ & & $28.5(1)$ & & 0.193 \\
\hline Candy, chocolate & $32.9(12)$ & 33.1 (135) & $34.2(33)$ & $34.1(19)$ & $30.5(2)$ & 0.177 & $34.3(5)$ & $32.7(82)$ & $31.6(49)$ & $35.1(15)$ & - & 0.404 & $33.3(31)$ & $34.6(77)$ & $34.3(35)$ & $35.8(31)$ & $34.0(6)$ & 0.031 \\
\hline Cookies, cakes & $33.9(42)$ & $33.0(123)$ & $33.3(23)$ & $34.6(13)$ & & 0.388 & $32.0(44)$ & $33.0(75)$ & $32.5(23)$ & $33.7(9)$ & - & 0.140 & $34.3(51)$ & $34.1(90)$ & $36.1(25)$ & $35.4(14)$ & & 0.069 \\
\hline Fulfat cheese & $32.9(89)$ & $34.2(43)$ & $33.2(46)$ & $33.5(22)$ & $36.1(1)$ & 0.200 & $32.5(90)$ & $33.2(24)$ & $32.7(23)$ & $32.9(14)$ & - & 0.295 & $32.8(56)$ & $35.5(27)$ & $34.9(40)$ & $35.5(57)$ & & 0.002 \\
\hline Softdrinks, light & $33.1(105)$ & $32.9(62)$ & $33.9(8)$ & $35.1(24)$ & $33.9(2)$ & 0.087 & $31.8(72)$ & $33.5(39)$ & $34.0(20)$ & $32.7(16)$ & $33.8(4)$ & 0.024 & 34.6 (108) & $33.7(21)$ & $35.8(17)$ & $33.9(24)$ & $35.2(10)$ & 0.489 \\
\hline Softdrinks, sugar sweetened & $33.4(88)$ & $32.9(84)$ & $33.7(14)$ & $35.0(14)$ & $28.1(1)$ & 0.413 & $32.9(46)$ & $32.9(72)$ & $32.6(21)$ & $30.7(10)$ & $31.5(2)$ & 0.191 & $34.0(115)$ & 35.5 (38) & $36.4(13)$ & $34.4(13)$ & $29.2(1)$ & 0.048 \\
\hline Fruit, vegetable juice & $33.8(66)$ & $33.6(72)$ & $32.8(21)$ & $32.3(42)$ & & 0.041 & 33.6 (43) & $32.5(49)$ & $32.5(30)$ & $31.6(28)$ & $32.3(1)$ & 0.260 & $34.4(82)$ & 34.8 (39) & $34.3(16)$ & $34.6(42)$ & $34.7(1)$ & 0.419 \\
\hline Water & $36.6(1)$ & $38.7(2)$ & $32.4(2)$ & $33.3(33)$ & $33.2(163)$ & 0.185 & $36.1(1)$ & $32.6(2)$ & $36.5(1)$ & $32.7(27)$ & $32.6(120)$ & 0.354 & $36.3(5)$ & & $32.1(5)$ & $35.7(31)$ & $34.3(139)$ & 0.155 \\
\hline Milk & $33.8(24)$ & $33.5(11)$ & 32.1 (9) & $33.2(120)$ & $33.7(37)$ & 0.266 & $32.7(23)$ & $31.3(13)$ & $32.0(7)$ & $33.2(78)$ & $32.1(30)$ & 0.486 & $34.9(76)$ & $33.3(13)$ & $35.16)$ & $34.7(75)$ & $32.1(10)$ & 0.177 \\
\hline
\end{tabular}

*Jonckheere-Terpstra test for trend 
Table A3. Intake of fat (E\%) from food record in relation to frequencies from NFFQ Iceland
13-17y

N

92

43

\begin{tabular}{|c|c|c|c|c|c|c|c|c|c|c|c|c|}
\hline \multirow[b]{2}{*}{$\begin{array}{l}\text { Food record } \\
\text { (gramperweek) }\end{array}$} & \multirow{2}{*}{$\begin{array}{l}\text { Per month } \\
\begin{array}{r}0-3 \text { times } \\
\text { Mean (n) }\end{array}\end{array}$} & \multicolumn{2}{|c|}{ Per week } & \multicolumn{2}{|c|}{ Per day } & \multirow[b]{2}{*}{ p-value* } & \multirow{2}{*}{$\begin{array}{c}\text { Per month } \\
\begin{array}{r}0-3 \text { times } \\
\text { Mean (n) }\end{array}\end{array}$} & \multicolumn{2}{|c|}{ Per week } & \multicolumn{2}{|c|}{ Per day } & \multirow[b]{2}{*}{ p-value* } \\
\hline & & $\begin{array}{l}1-2 \text { times } \\
\text { Mean }(n)\end{array}$ & $\begin{array}{l}3-6 \text { times } \\
\text { Mean }(n)\end{array}$ & $\begin{array}{l}1-2 \text { times } \\
\text { Mean }(n)\end{array}$ & $\begin{array}{r}3 \text { times or more } \\
\text { Mean }(n)\end{array}$ & & & $\begin{array}{l}1-2 \text { times } \\
\text { Mean }(n)\end{array}$ & $\begin{array}{c}3-6 \text { times } \\
\text { Mean }(n)\end{array}$ & $\begin{array}{l}1-2 \text { times } \\
\text { Mean }(n)\end{array}$ & $\begin{array}{r}3 \text { times or mor } \\
\text { Mean }(n)\end{array}$ & \\
\hline Rye bread, slices & $32,4(45)$ & $32,2(40)$ & $30,9(5)$ & $34,3(1)$ & $37,6(1)$ & 0.821 & $32,0(25)$ & $31,2(16)$ & $29,5(1)$ & & - & 0.367 \\
\hline Wholemeal bread, slices & $32,3(58)$ & $33,1(12)$ & $32,2(6)$ & $31,7(11)$ & $31,5(5)$ & 0.698 & $31,9(30)$ & $32,7(5)$ & $30,9(3)$ & $27,2(2)$ & $30,8(2)$ & 0.268 \\
\hline Wheat bread, slices & $32,8(8)$ & $31,2(8)$ & $32,7(13)$ & $32,3(46)$ & $32,3(17)$ & 0.980 & $28,5(3)$ & $31,2(3)$ & $30,8(8)$ & $31,4(19)$ & $34,2(9)$ & 0.053 \\
\hline Vegetables & $31,6(2)$ & $32,3(10)$ & $32,8(15)$ & $32,1(53)$ & $32,7(12)$ & 0.901 & & $32,8(3)$ & $32,4(6)$ & $31,4(32)$ & $32,0(1)$ & 0.193 \\
\hline Fruits & & $35,3(2)$ & $33,4(11)$ & $32,0(69)$ & $32,7(10)$ & 0.484 & & $30,8(3)$ & $33,4(8)$ & $30,5(23)$ & $33,5(10)$ & 0.952 \\
\hline Pommes frites & $32,0(76)$ & $33,8(16)$ & & - & & 0.104 & $31,3(37)$ & $34,2(5)$ & & - & - & 0.065 \\
\hline Fish & $33,4(8)$ & $32,3(60)$ & $31,9(23)$ & - & - & 0.392 & $29,7(4)$ & $32,0(29)$ & $31,6(9)$ & - & - & 0.445 \\
\hline Sausages & $32,6(57)$ & $31,9(33)$ & $32,4(1)$ & - & - & 0.474 & $31,3(27)$ & $32,0(13)$ & $34,0(2)$ & - & - & 0.182 \\
\hline Candy, chocolate & $34,4(5)$ & $32,2(78)$ & $31,6(9)$ & - & - & 0.120 & $34,8(5)$ & $31,1(31)$ & $31,3(5)$ & $36,7(1)$ & - & 0.821 \\
\hline Cookies, cakes & $33,2(10)$ & $31,9(35)$ & $31,8(35)$ & $34,2(12)$ & & 0.435 & $32,5(14)$ & $30,4(17)$ & $32,2(9)$ & $34,4(2)$ & - & 0.738 \\
\hline Fulfat cheese & $31,7(20)$ & $32,3(10)$ & $33,1(24)$ & $31,9(32)$ & $33,2(6)$ & 0.470 & $30,2(6)$ & $29,7(4)$ & $31,3(10)$ & $32,0(17)$ & $34,8(5)$ & 0.120 \\
\hline Softdrinks, light & $32,7(53)$ & $32,3(24)$ & $31,6(12)$ & $28,1(3)$ & - & 0.044 & $31,8(14)$ & $32,7(10)$ & $31,3(9)$ & $29,1(5)$ & - & 0.536 \\
\hline Softdrinks, sugar sweetened & $32,2(42)$ & $32,3(35)$ & $33,9(10)$ & $30,3(5)$ & - & 0.488 & $32,1(16)$ & 32,3 (16) & $28,2(6)$ & $33,0(2)$ & - & 0.564 \\
\hline Fruit, vegetable juice & $33,8(18)$ & $32,5(18)$ & $32,5(25)$ & $31,1(30)$ & $32,6(1)$ & 0.021 & $32,8(4)$ & 32,9 (11) & $31,2(15)$ & 30,4 (9) & $33,1(2)$ & 0.177 \\
\hline Water & $31,2(1)$ & 0 & $31,6(2)$ & $32,9(19)$ & $32,4(61)$ & 0.955 & & - & - & $31,2(8)$ & $32,3(26)$ & 0.626 \\
\hline Milk & $31,9(7)$ & $35,4(3)$ & $31,8(7)$ & $32,6(54)$ & $31,5(21)$ & 0.578 & $27,7(2)$ & $34.0(1)$ & $32,1(4)$ & $31,0(25)$ & $33,3(9)$ & 0.561 \\
\hline
\end{tabular}

*Jonckheere-Terpstra test for trend 
Table A4. Intake of saturated fat (E\%) without alcohol from food record in relation to frequencies from NFFQ Denmark

\begin{tabular}{|c|c|c|c|c|c|c|c|c|c|c|c|c|c|c|c|c|c|c|}
\hline \multirow{3}{*}{ Age group } & \multicolumn{6}{|c|}{$7-12 y$} & \multicolumn{6}{|c|}{$13-17 y$} & \multicolumn{6}{|c|}{$18-65 y$} \\
\hline & \multirow{3}{*}{$\begin{array}{r}\text { Per month } \\
0-3 \text { times } \\
\text { Mean (n) }\end{array}$} & \multicolumn{4}{|c|}{201} & & \multicolumn{6}{|c|}{151} & \multicolumn{6}{|c|}{180} \\
\hline & & \multicolumn{2}{|c|}{ Per week } & \multicolumn{2}{|c|}{ Per day } & & \multirow{2}{*}{$\begin{array}{l}\text { Per month } \\
0-3 \text { times } \\
\text { Mean (n) }\end{array}$} & \multicolumn{2}{|c|}{ Per week } & \multicolumn{2}{|c|}{ Per day } & & \multirow{2}{*}{$\begin{array}{r}\begin{array}{r}\text { Per } \\
\text { month }\end{array} \\
0-3 \text { times } \\
\text { Mean }(n)\end{array}$} & \multicolumn{2}{|c|}{ Per week } & \multicolumn{2}{|c|}{ Per day } & \multirow[b]{2}{*}{$\mathrm{p}$-value* } \\
\hline $\begin{array}{l}\text { Food record } \\
\text { (gramperweek) }\end{array}$ & & $\begin{array}{r}1-2 \text { times } \\
\text { Mean }(n)\end{array}$ & $\begin{array}{l}3-6 \text { times } \\
\text { Mean }(n)\end{array}$ & $\begin{array}{r}1-2 \text { times } \\
\text { Mean }(n)\end{array}$ & $\begin{array}{l}3 \text { times } \\
\text { or more } \\
\text { Mean }(n)\end{array}$ & & & $\begin{array}{r}1-2 \text { times } \\
\text { Mean }(n)\end{array}$ & $\begin{array}{l}3-6 \text { times } \\
\text { Mean }(n)\end{array}$ & $\begin{array}{c}1-2 \text { times } \\
\text { Mean }(n)\end{array}$ & $\begin{array}{l}3 \text { times } \\
\text { or more } \\
\text { Mean }(n)\end{array}$ & & & $\begin{array}{r}1-2 \text { times } \\
\text { Mean }(n)\end{array}$ & $\begin{array}{r}3-6 \text { times } \\
\text { Mean }(n)\end{array}$ & $\begin{array}{r}1-2 \text { times } \\
\text { Mean }(n)\end{array}$ & $\begin{array}{l}3 \text { times } \\
\text { or more } \\
\text { Mean }(n)\end{array}$ & \\
\hline Rye bread, slices & $13.4(3)$ & $11.1(2)$ & $13.5(5)$ & $13.8(138)$ & $14.4(53)$ & 065 & $13.4(7)$ & $13.1(4)$ & $14.0(21)$ & $13.9(79)$ & $13.9(40)$ & 0.432 & $16.0(2)$ & $15.0(9)$ & $14.5(4)$ & $14.0(102)$ & $14.8(61)$ & 0.152 \\
\hline Wholem & & (29) & $13.7(43)$ & & & & $14.5(25)$ & $13.8(15)$ & & & 12.9 & 0.010 & $14.7(30)$ & & $13.7(30)$ & $14.5(72)$ & 14.6 & 0.348 \\
\hline Wheat bread, slic & $13.2(47)$ & $14.1(61)$ & $14.5(37)$ & $13.9(49)$ & $15.0(7)$ & 0.024 & $13.3(31)$ & $14.0(35)$ & $13.9(28)$ & $14.1(49)$ & $14.6(8)$ & 0.041 & $13.9(74)$ & $14.1(54)$ & $16.0(18)$ & $14.7(27)$ & $14.6(7)$ & 0.031 \\
\hline Vegetables & $13.7(2)$ & $14.4(12)$ & $15.1(23)$ & $13.8(147)$ & $13.0(17)$ & 0.012 & $15.6(5)$ & $14.8(14)$ & $14.7(18)$ & $13.6(106)$ & $13.2(8)$ & 0.004 & $15.2(3)$ & $16.5(12)$ & $14.8(28)$ & $14.1(124)$ & $13.3(13)$ & 0.002 \\
\hline Fruits & $16.3(1)$ & $14.0(4)$ & $14.9(19)$ & $14.1(131)$ & $13.0(46)$ & $<0.001$ & $16.1(4)$ & $14.9(14)$ & $15.2(11)$ & $13.9(77)$ & $13.1(45)$ & $<0.001$ & $17.3(6)$ & $15.3(10)$ & $16.4(16)$ & $14.5(91)$ & $13.0(57)$ & $<0.001$ \\
\hline Pommes frites, fried potatoes & 14.0 (139) & $13.9(54)$ & $12.8(8)$ & & - & 0.263 & $13.9(89)$ & $14.1(49)$ & $13.2(13)$ & & & 0.442 & $14.2(129)$ & $14.8(47)$ & $12.6(2)$ & $14.6(1)$ & 14.0 (1) & 0.065 \\
\hline Fish & $13.5(48)$ & $14.0(101)$ & $14.2(38)$ & $14.4(14)$ & - & 0.108 & $14.5(40)$ & $13.8(88)$ & $13.0(16)$ & $12.7(6)$ & $15.7(1)$ & 0.018 & $15.6(38)$ & $14.4(80)$ & $13.7(42)$ & $13.5(19)$ & $9.1(1)$ & $<0.001$ \\
\hline Sausages & 14.0 (186) & 13.5 (14) & & & $14.3(1)$ & 0.395 & 13.9 (144) & $13.1(7)$ & & & - & 0.208 & $14.4(175)$ & $13.8(4)$ & & $10.7(1)$ & & 0.151 \\
\hline Candy, chocolate & $13.7(12)$ & $13.7(135)$ & $14.6(33)$ & $14.7(19)$ & $12.8(2)$ & 0.057 & $14.1(5)$ & $13.9(82)$ & $13.4(49)$ & $15.1(15)$ & - & 0.428 & $13.9(31)$ & $14.4(77)$ & $14.0(35)$ & $15.0(31)$ & $15.0(6)$ & 0.061 \\
\hline Cookies, cakes & $14.0(42)$ & $13.7(123)$ & $14.2(23)$ & $15.0(13)$ & & 0.250 & $13.8(44)$ & $13.9(75)$ & $13.6(23)$ & $14.8(9)$ & - & 0.272 & $14.3(51)$ & $14.0(90)$ & $15.3(25)$ & $15.0(14)$ & - & 0.076 \\
\hline Fulfat cheese & $13.6(89)$ & $14.3(43)$ & $13.9(46)$ & $14.4(22)$ & $15.5(1)$ & 0.082 & $13.8(90)$ & $13.8(24)$ & $13.8(23)$ & $14.7(14)$ & - & 0.222 & $13.1(56)$ & $14.7(27)$ & $14.8(40)$ & $15.1(57)$ & . & $<0.001$ \\
\hline Softdrinks, light & $13.9(105)$ & $13.5(62)$ & $14.1(8)$ & $14.9(24)$ & $14.5(2)$ & 0.164 & $13.5(72)$ & $13.9(39)$ & $14.7(20)$ & $14.2(16)$ & $15.2(4)$ & 0.019 & $14.3(108)$ & $14.2(21)$ & $14.7(17)$ & $14.5(24)$ & $14.6(10)$ & 0.200 \\
\hline Softdrinks, sugar sv & $13.9(88)$ & $13.7(84)$ & $14.8(14)$ & $15.3(14)$ & $11.3(1)$ & 0.100 & $14.0(46)$ & $14.0(72)$ & $13.8(21)$ & $13.2(10)$ & $13.6(2)$ & 0.326 & $14.0(115)$ & $14.8(38)$ & $15.9(13)$ & $14.7(13)$ & $12.9(1)$ & 0.013 \\
\hline Fruit, vegetable juice & $13.9(66)$ & $14.2(72)$ & $13.7(21)$ & $13.7(42)$ & & 0.221 & $14.4(43)$ & $13.7(49)$ & $14.1(30)$ & $13.2(28)$ & $12.6(1)$ & 0.371 & $14.4(82)$ & $14.4(39)$ & $13.9(16)$ & $14.3(42)$ & $13.7(1)$ & 0.228 \\
\hline Water & $18.7(1)$ & $17.2(2)$ & $14.3(2)$ & $14.1(33)$ & $13.8(163)$ & 0.086 & $16.3(1)$ & $13.5(2)$ & $17.3(1)$ & $14.1(27)$ & $13.8(120)$ & 0.173 & $15.2(5)$ & & $13.8(5)$ & $15.3(31)$ & $14.1(139)$ & 0.019 \\
\hline Milk & $13.9(24)$ & $14.0(11)$ & $13.5(9)$ & $13.8(120)$ & $14.4(37)$ & 0.096 & $13.5(23)$ & $12.9(13)$ & $13.2(7)$ & $14.2(78)$ & $14.0(30)$ & 0.084 & $14.3(76)$ & $14.3(13)$ & $14.5(6)$ & $14.5(75)$ & $13.5(10)$ & 0.489 \\
\hline
\end{tabular}

*Jonckheere-Terpstra test for trend 
Table A5. Intake of saturated fat (E\%) from food record in relation to frequencies from NFFQ Iceland

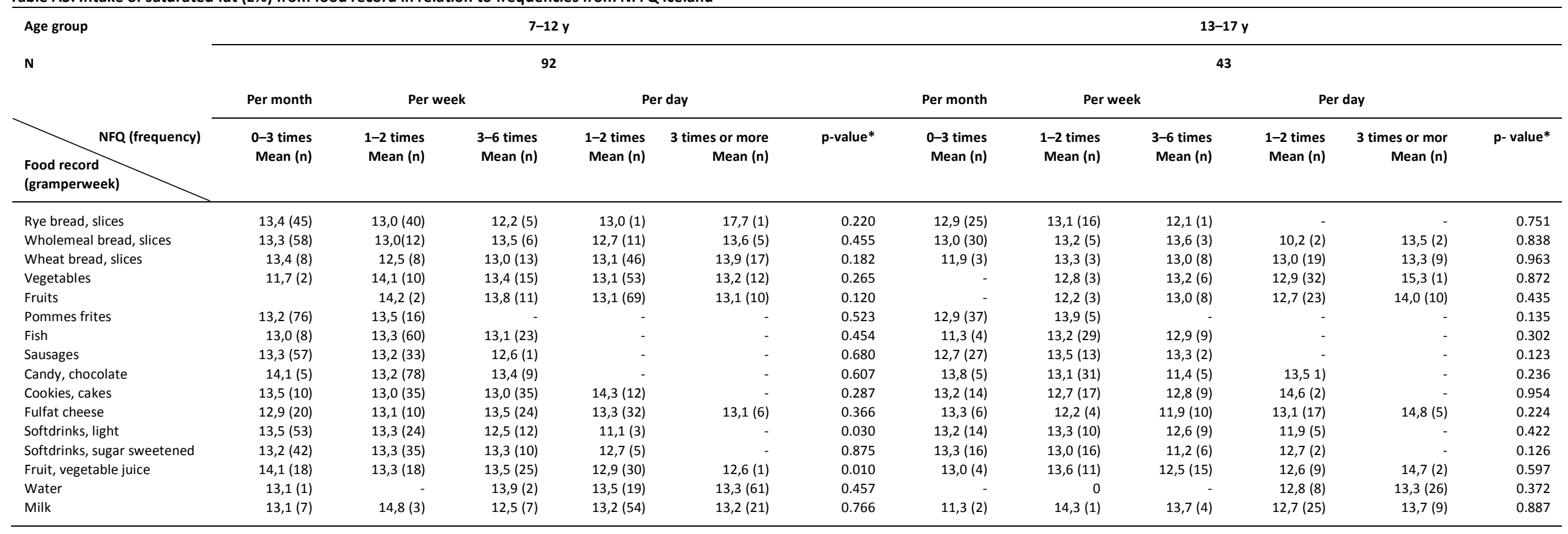

*Jonckheere-Terpstra test for trend 
Table A6. Intake of sugar (E\%) with out alcohol from food record in relation to frequencies from NFFQ Denmark

\begin{tabular}{|c|c|c|c|c|c|c|c|c|c|c|c|c|c|c|c|c|c|c|}
\hline \multirow{3}{*}{ Age group } & \multicolumn{6}{|c|}{$7-12 y$} & \multicolumn{6}{|c|}{$13-17 y$} & \multicolumn{6}{|c|}{$18-65 y$} \\
\hline & \multirow{3}{*}{$\begin{array}{r}\begin{array}{r}\text { Per } \\
\text { month }\end{array} \\
0-3 \text { times } \\
\text { Mean (n) }\end{array}$} & \multicolumn{4}{|c|}{201} & & \multicolumn{6}{|c|}{151} & \multicolumn{6}{|c|}{180} \\
\hline & & \multicolumn{2}{|c|}{ Per week } & \multicolumn{2}{|c|}{ Per day } & \multirow[b]{2}{*}{ p-value* } & \multirow{2}{*}{$\begin{array}{r}\begin{array}{r}\text { Per } \\
\text { month }\end{array} \\
\begin{array}{r}3-6 \text { times } \\
\text { Mean }(n)\end{array}\end{array}$} & \multicolumn{2}{|c|}{ Per week } & \multicolumn{2}{|c|}{ Per day } & \multirow[b]{2}{*}{ p-value* } & \multirow{2}{*}{$\begin{array}{r}\begin{array}{r}\text { Per } \\
\text { month }\end{array} \\
\begin{array}{r}3-6 \text { times } \\
\text { Mean }(n)\end{array}\end{array}$} & \multicolumn{2}{|c|}{ Per week } & \multicolumn{2}{|c|}{ Per day } & \multirow[b]{2}{*}{ p-value* } \\
\hline $\begin{array}{l}\text { Food record } \\
\text { (gram per week) }\end{array}$ & & $\begin{array}{l}1-2 \text { times } \\
\text { Mean }(n)\end{array}$ & $\begin{array}{l}3-6 \text { times } \\
\text { Mean }(n)\end{array}$ & $\begin{array}{l}1-2 \text { times } \\
\text { Mean }(n)\end{array}$ & $\begin{array}{l}3 \text { times } \\
\text { or more } \\
\text { Mean }(n)\end{array}$ & & & $\begin{array}{l}1-2 \text { times } \\
\text { Mean }(n)\end{array}$ & $\begin{array}{l}3-6 \text { times } \\
\text { Mean }(n)\end{array}$ & $\begin{array}{l}1-2 \text { times } \\
\text { Mean }(n)\end{array}$ & $\begin{array}{l}3 \text { times } \\
\text { or more } \\
\text { Mean }(n)\end{array}$ & & & $\begin{array}{r}1-2 \text { times } \\
\text { Mean }(n)\end{array}$ & $\begin{array}{r}3-6 \text { times } \\
\text { Mean (n) }\end{array}$ & $\begin{array}{r}1-2 \text { times } \\
\text { Mean }(n)\end{array}$ & $\begin{array}{r}3 \text { times } \\
\text { or more } \\
\text { Mean }(n)\end{array}$ & \\
\hline Rye bread, slices & $10.5(3)$ & $7.0(2)$ & $7.3(5)$ & $9.6(138)$ & $9.8(53)$ & 0.194 & $13.5(7)$ & $11.7(4)$ & $10.2(21)$ & $10.4(79)$ & $9.6(40)$ & 0.150 & $12.8(2)$ & $11.5(9)$ & $9.9(4)$ & $8.5(104)$ & $8.0(61)$ & 0.082 \\
\hline Wholemeal bread, slices & $9.4(38)$ & $8.5(29)$ & $9.3(43)$ & $10.3(82)$ & $9.9(9)$ & 0.122 & $107(25)$ & $9.8(15)$ & $9.4(27)$ & $10.2(63)$ & $11.7(21)$ & 0.291 & $10.2(30)$ & $8.7(37)$ & $8.1(30)$ & $8.2(72)$ & $7.3(11)$ & 0.055 \\
\hline Wheat bread, slices & $9.2(47)$ & $10.4(61)$ & $9.2(37)$ & $9.9(49)$ & $7.3(7)$ & 0.425 & $9.9(31)$ & $9.5(35)$ & $9.4(28)$ & $11.6(49)$ & $11.3(8)$ & 0.025 & $7.5(74)$ & $8.6(54)$ & $8.5(18)$ & $10.7(26)$ & $11.2(7)$ & 0.003 \\
\hline Vegetables & $9.5(2)$ & $13.3(12)$ & $9.5(23)$ & $9.5(147)$ & $8.9(17)$ & 0.077 & $9.8(5)$ & $12.5(14)$ & $11.8(13)$ & $9.7(106)$ & $12.1(8)$ & 0.133 & $10.8(3)$ & $10.0(12)$ & $10.2(28)$ & $8.0(124)$ & $7.9(13)$ & 0.005 \\
\hline Fruits & $11.8(1)$ & $7.9(4)$ & 8.9 (19) & $9.6(131)$ & $10.3(46)$ & 0.297 & $10.4(4)$ & $10.5(14)$ & $10.5(11)$ & $9.8(77)$ & $11.2(45)$ & 0.261 & $11.0(6)$ & $10.4(10)$ & $10.5(16)$ & $8.5(91)$ & $7.4(57)$ & 0.001 \\
\hline Pommes frites, fried potatoes & $9.5(139)$ & $10.1(54)$ & $8.6(8)$ & & & 0.341 & $9.8(89)$ & $11.0(49)$ & $11.0(13)$ & & & 0.091 & $8.4(129)$ & $8.7(47)$ & $9.9(2)$ & $10.8(1)$ & $11.7(1)$ & 0.185 \\
\hline Fish & $9.8(48)$ & $9.2(101)$ & $11.3(38)$ & $8.2(14)$ & . & 0.360 & $10.5(40)$ & $9.8(88)$ & $12.2(16)$ & $13.0(6)$ & $6.7(1)$ & 0.362 & $9.9(38)$ & $8.4(80)$ & $7.9(42)$ & $7.3(19)$ & $21.1(1)$ & 0.050 \\
\hline Sausages & $9.7(186)$ & $9.7(14)$ & & & $7.7(1)$ & 0.479 & $10.0(144)$ & $16.0(7)$ & & & - & 0.010 & $8.5(175)$ & $9.0(4)$ & & $12.0(1)$ & & 0.143 \\
\hline Candy, chocolate & $8.9(12)$ & $9.4(135)$ & $10.5(33)$ & $10.1(19)$ & $11.6(2)$ & 0.063 & $6.8(5)$ & $9.5(82)$ & $12.0(49)$ & $10.5(15)$ & - & 0.005 & $7.5(31)$ & $7.8(77)$ & $8.6(35)$ & $10.7(31)$ & $12.0(6)$ & $<0.001$ \\
\hline Cookies, cakes & $9.0(42)$ & $9.6(123)$ & $9.8(23)$ & $12.2(13)$ & & 0.041 & $10.3(44)$ & $9.8(75)$ & $11.2(23)$ & $12.7(9)$ & 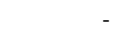 & 0.185 & $7.8(51)$ & $8.5(90)$ & $10.2(25)$ & $8.4(14)$ & & 0.015 \\
\hline Fulfat cheese & $9.9(89)$ & $10.2(43)$ & $9.3(46)$ & $8.5(22)$ & $9.5(1)$ & 0.259 & $10.7(90)$ & $8.0(24)$ & $10.1(23)$ & $12.2(14)$ & & 0.256 & $8.2(56)$ & $9.2(27)$ & $7.7(40)$ & $9.1(57)$ & & 0.129 \\
\hline Softdrinks, light & $9.8(105)$ & $9.7(62)$ & $7.6(8)$ & $9.5(24)$ & $9.7(2)$ & 0.360 & $10.4(72)$ & $9.9(39)$ & $10.7(20)$ & $10.1(16)$ & $11.3(4)$ & 0.445 & $8.2(108)$ & $7.2(21)$ & $9.3(17)$ & $9.9(24)$ & $10.5(10)$ & 0.062 \\
\hline Softdrinks, sugar s & $8.4(88)$ & $10.0(84)$ & $13.0(14)$ & $11.8(14)$ & $15.0(1)$ & $<0.001$ & $9.0(46)$ & $9.8(72)$ & $11.7(21)$ & $16.5(10)$ & $12.5(2)$ & $<0.001$ & $7.6(115)$ & $8.7(38)$ & $10.9(13)$ & $13.3(13)$ & $22.7(1)$ & $<0.001$ \\
\hline Fruit, vegetable juice & $9.3(66)$ & $9.6(72)$ & $10.6(21)$ & $9.9(42)$ & & 0.057 & $10.4(43)$ & $9.5(49)$ & $10.8(30)$ & $11.3(28)$ & $6.9(1)$ & 0.147 & $8.9(82)$ & $8.9(39)$ & $6.9(16)$ & $8.2(42)$ & $7.6(1)$ & 0.102 \\
\hline Water & $15.0(1)$ & $16.9(2)$ & $8.9(2)$ & $10.2(33)$ & $9.4(163)$ & 0.265 & $9.6(1)$ & $9.6(2)$ & $16.6(1)$ & $10.3(27)$ & $10.3(120)$ & 0.426 & $14.0(5)$ & & $14.3(5)$ & $9.5(31)$ & 7.9 (139) & 0.001 \\
\hline Milk & $9.5(24)$ & $11.3(11)$ & $12.2(9)$ & $9.7(120)$ & $8.6(37)$ & 0.041 & $11.5(23)$ & $11.2(13)$ & $10.5(7)$ & $10.1(78)$ & $9.5(30)$ & 0.087 & $8.5(76)$ & $9.4(13)$ & $8.3(6)$ & $8.5(75)$ & $8.3(10)$ & 0.322 \\
\hline
\end{tabular}

*Jonckheere-Terpstra test for trend 
Table A7. Intake of sugar (E\%) from food record in relation to frequencies from NFFQ Iceland

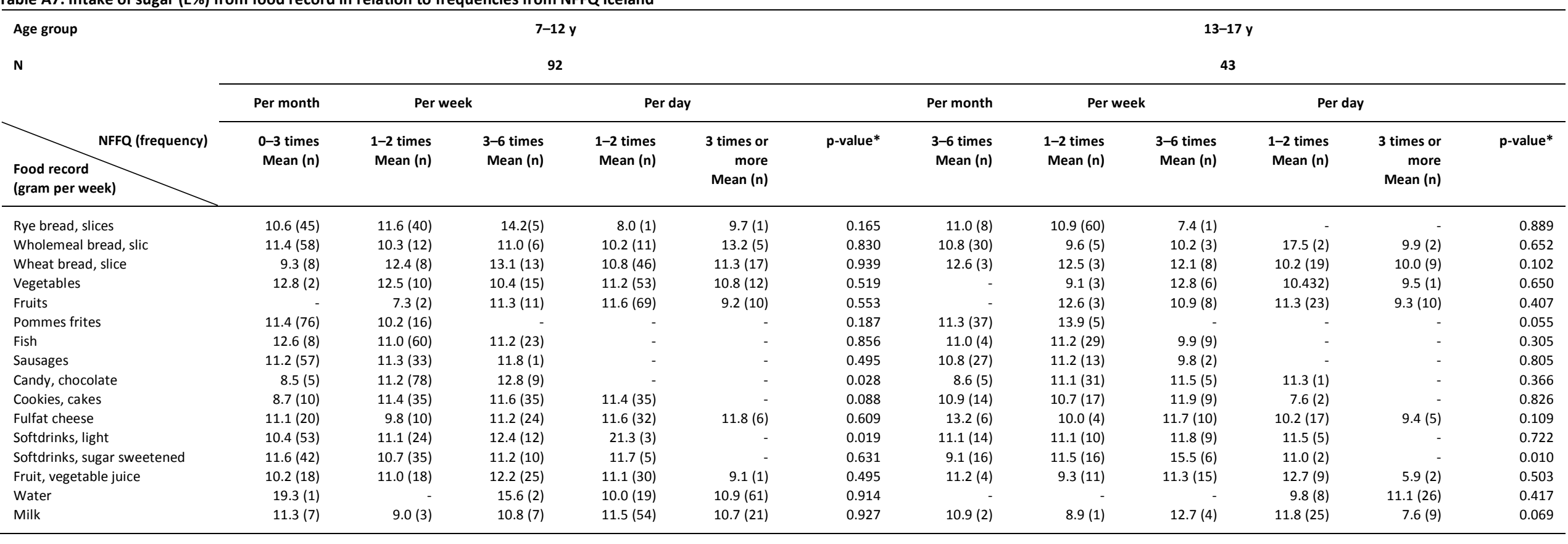

*Jonckheere-Terpstra test for trend 
Table A8. Intake of dietary fibre ( $\mathrm{g} / 10 \mathrm{MJ})$ from food record in relation to frequencies from NFFQ Denmark

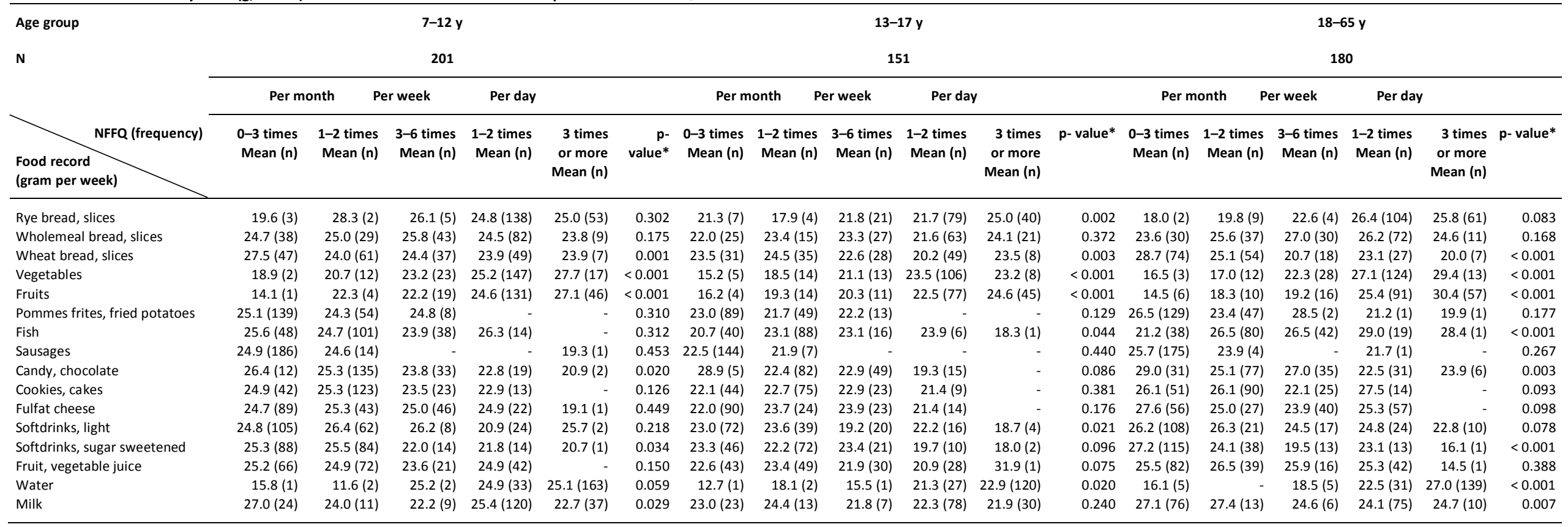

*Jonckheere-Terpstra test for trend 


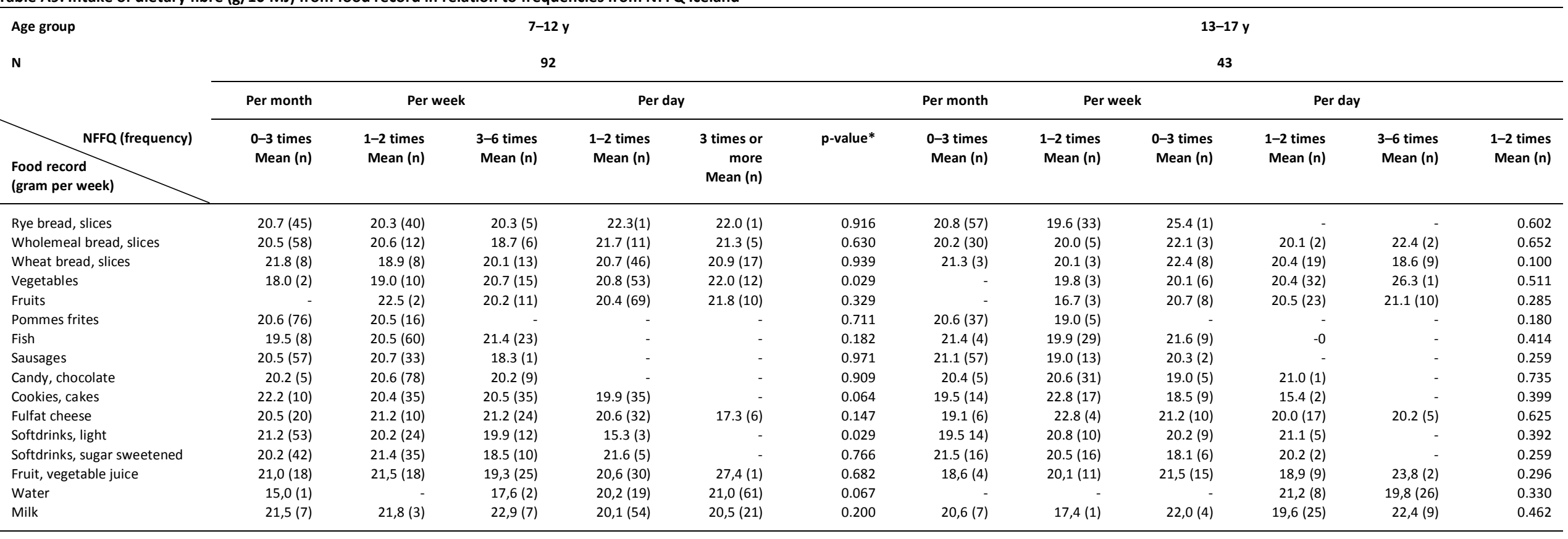

*Jonckheere-Terpstra test for trend 
Nordic Council of Ministers

Ved Stranden 18

DK-1061 Copenhagen $\mathrm{K}$

www.norden.org

\section{Nordic Monitoring of diet, physical activity and overweight}

Validation of indicators

In 2007, a Nordic working group was established with the aim to describe a future Nordic monitoring system on diet, physical activity and overweight. The monitoring system should be simple and at relatively low cost. Therefore it has been decided to conduct the monitoring as a telephone interview. In 2009, the indicator questions were validated against an objective method (physical activity) or existing survey methods (diet) and the present report mainly describes the validation studies. On basis of the validation studies the working group suggests that the indicators are used in a future monitoring system. In 2011 and 2013 the first collection of data in all Nordic countries will take place. 